





\section{THE}

\section{SNAKES OF AUSTRALIA; 2,3 AS}

\section{ILLUSTRATED AND DESCRIPTIVE CATALOGUE OF ALL THE KNOWN SPECIES.}

$\mathrm{BY}$

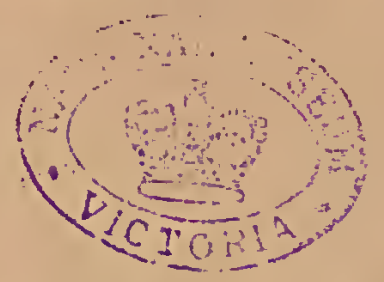

GERARD KREFET, F.L.S., C.M.Z.S., \&c., \&c., \&c., CURATOR AND SECRfTARY OF THE AUSTRALIAN MUSEUM.

Suntuet :

THONLS RICHARDS, GOVERTMENT PRINTER, PHILLIP-STREET. 



\section{PREFACE.}

The present descriptive Catalogue contains a full account of nearly all the Australian Snakes discovered and recorded up to the year 1868, including the Sca Snakes observed on our const. Original descriptions have been retained wherever it was possible, error's have been corrected, and the ranges of the rarious species defiued. Much attention has becn paid to the colors of living specimens, aud to the changes ophidian reptiles undergo during the period of growth. Frequent expcriments hare enabled me to distinguish between venomous and dangerous veuomous snakes; and it must be a source of congratulation that, with the many new discoveries in this branch of Natural History during the last ten years, not one really dange rous serpent has been added to our fauna. .

In 1854, about tweuty Australian Snakes were known; five years later, thirty were enumerated in Dr. Günther's Catalogue; and now, nearly serenty species are on reeord. Science owes much to the cnergy of the Trustees of the Australian M[useum, who, with very limited means, hare kcpt a most able and enthusiastie collector (Mr. George Masters) in the field; and I do not think I am far wrong in stating that two-thirds of these newly discorered species were first exhibited in Sydney.

I am under deep obligations to Dr. Albert Günther, F.R.S., of the British Museum, whose splendid work on "The Reptiles of British India" has enabled me to add a full account of the Australian Sea Snakes. The gifted daughters of A. W. Scott, Esq., M.A.— Miss Scott, and Mrs. Edward Forde-have done everything in their power to give correct figures of the reptiles illustrated. This task (one of peculiar difficulty, as erery naturalist knows) has been well carricd out, and the different species will be easily recoguized.

I thank all the kind contributors to the MInseum-in particular, the Messrs. MITntosh, of Lame Cove and Marsh Bank; Mr. Houghton Bradley, Mr. Arch. Boyd, Mir. Edward S. Hill, Mr. Edward Bclisario, and others, who, during a period of nine years, have enriched our collection with numerous specimens, and through whose exertions the dangerous snakes of the neighbourhood of Sydney have been considerably reduced.

I shall feel thaukful if occasioual mistakes are pointed out to me; and if sufficieut encouragement is offered, I hope to continue publicatious of a similar character.

G. K.

Hydc Park,

Woolloomooloo, MLarch 20, 1869. 



\section{5. \\ THE ORDER OF SNAKES-OPHIDIA.}

The principal characteristic of this order is an exceedingly elongate body, covered with scales, and either destitute of limbs, or provided with very rudimentary ones, in the form of a spur on each side of the rent.

Snakes propel themselves by lateral undulations, with the aid of sharp-cdged abdominal plates, and loosely articulated ribs moving with the vertebral column, as thus described by Günther :- "When a part of their body has found some projection of the ground which affords it some point of support, the ribs, alternately of one and "the other side, are drawn more closely together, thereby producing alternate bends of the body on the corresponding side. The hinder portion of the body being drawn after, some part of it finds another support on the rough ground or a projection; and, the anterior bends being stretched in a straight line, the front part of the body is propelled in consequence. During this peculiar kind of locomotion, the broad shields of the belly are of great advantage, as by means of the free edges of those shields they are enabled to catch the smallest projections on the ground, which may be used as points of support. A pair of ribs correspond to each of these ventral shields. The snakes are not ablc to move over a perfectly smooth surface."

The number of abdominal plates generally corresponds to the number of vertebri, the ribs being double that number. These plates are of some value as a distinguishing characteristic between venomous and non-venomous snakes. Thus (speaking of Australian species) snakes with more than 240 abdominal plates, are generally not venomous, as so large a numbcr has never been noticed in any other than the Boa or Python tribe, and some of the Tree Snakes of the genus Dipsas. They have neither breastbone or sternum nor eyelids, and both jaws and the palatc are usually toothed; the mandibles, which are united in front by an clastic ligament, are generally very extensiblc. 
Snakes are naked, that is, they are not supplied with any external covering such as hair or feathers. Their epidermis is laid in scale-like folds ou the back and sides, and forms plates on the belly, and generally broad though not imbricate plates on the crown (exeept in the genus Moretia-the Diamond and Carpet Snakes-whieh have the head eovercd with numerous irregular small seale-like plates). The epidermis is shed, at regular intervals, several times a year, and removed in one piece, including the part over the eyes, which, being without lids, may bc easily traced in the east-off skin. At some period before the epidermis is shed, the snake retires to a quiet, and, if possible, damp place, wherc the skin soon loses the usual gloss and beeomes opaque, whilst the eyes grow blind, as the new skin is formed beneath the used-up epidermis. When ready, the reptile seleets a forked braneh, or the eleft of a rock, and, pressing through, emerges from the old eovering, which is left complete, and turued inside out behind. The shedding of the skin in a perfect state is a sign of good health; but when removed in shreds, the snake is suffering from some malady. Shortly after this metamorphosis scrpents become very sensitive, and more inelined to bite, when disturbed, than at other times.

The teeth are hook-like, eurved baekwards, very sharp, and designed for retaining, not erushing or mastieating, the prey; with few exceptions, the palate is furnished with tecth also.

All the viscera are of a peeuliar elongate form, there is but one lung developed, and the organs of generation are double. Some scrpents bring forth their young alive, others lay eggs, but in many eases these eggs when deposited eontain already well-developed young. Only one family - the Pythons-incubate their eggrs.

The division between Snakes and Lizards is not elearly defined, and one group merges into the other by seareely pereeptible degrees. The first family of Blind Snakes presents many eharaeters which remind us of the lizard type; such as the large, polished, adherent, and rounded scalcs, the narrow month, and the frequent absenee of the gular furrow peculiar to almost all Ophidians.

Some authors have elassed the Blind Snakes with the Lizards, but they differ from them in the loose eonnection of their jaw-bones-it charaeter whieh, according to Günther, must be considered as peculiar to 
the Ophidians, and which is only somewhat less developed in Blind Snakes and other Burrowing Serpents than in the typical forms. The two halves of the lowcr jaw in Ophidians arc only united by an elastic ligament, and even the bony portions of the head are not firmly joined together, and, with the exception of the part protecting the brain, admit of a certain degree of expansion; by which mcans these snakes are enabled to extend thcir gape to an extraordinary degree, and swallow animals larger than themselves.

Some kinds, such as the Australian Rock Snakes, are furnished with rudimentary hind limbs, in the form of small spur-like appendages near the vent, which, being absent from venomous species, serve as an indication that the reptiles which possess them are harmless.

In a state of repose, scrpents gencrally coil themselves up with their heads resting upon top of the coil. They are enabled to raise the body for a sloort time to about half its length without any support, but in a few seconds the raised part falls to the ground; this may perhaps account for current stories about snakes springing at men and beasts. Those Australian Snakes which are allied to the Najas of India, such as the Black, Brownhanded, and Tiger Snakes, when irritated, remain for some time with their licads erect and moving backwards and forwards ready to strike, but no more than a third of their body is thus elevated. Nearly all snakes are good climbers, and with the least assistance, such as the sides of a box, they can support the whole body, resting upon nothing but a part of the tail; eren the short clumsy Death Adder is capablc of pcrforming this feat.

The climbing power of the arborcal species-'Tree Snakes and Rock Snakes-is truly wonderful. For instance, Tree Snakes which had been closely confined in an empty room, and could not be found for some time, were at last discovered upon the moulding of a door nine feet from the ground.

Beyond a hissing and often peculiar drumming noise, snakes emit no sound. Neither the harmless nor venomous kinds will offer to bite unless they are hurt or driven into a corner whence escape is difficult, and if left alone they will scarcely stir. An instance is known of a person who picked $\mu_{p}$ several stones close to a large Black Snake, without observing his danger till warned by the hissing sound peculiar to snakes when molested; but no sooner had he proceeded to attack the reptile, by raising his foot to crush it, than it uncoiled and escaped. 
The harmless Ground Snakes, the Fresh Water Snakes, and the venomous kinds generally, attaek the smaller animals, such as frogs, lizards, and miee; they seize their prey and begin to swallow it at once. The arboreal speeies, and partieularly the Pythons, kill theirs by pressure.

As a rule, venomous snakes bite and then let go, but the Pythons retain their hold ; thus, it is hard to disengage one's finger from between the jaws of a Rock Snake, for if main force be used the flesh will be torn to shreds, as all its teeth are eurved backwards.

Mueh as has been said and written about the size and power of Boas and Pythons, little can be relied on. The largest speeimens seldom exceed 20 feet in length, and an Australian Roek Snake of 10 or 11 feet must be considered a monster. The swallowing power of these reptiles las also been greatly exaggerated; so that the aceounts we read in certain old travellers' journals, of snakes devouring stags and he-goats, horns and all, may be taken for what they are worth. Persons eonversant with their habits will be aware that the quarry is always swallowed by them head first, so that engulphing a ereature with horns of even moderate size would be next to impossible. Sueh stories as Waterton tells of his Dutch friend, who killed a Boa 20 feet long, that had a pair of stag's horus in its mouth, and was apparcntly waiting for the body just swallowed to be digested, are nothing but canards. The same author has treated us to other stories about the Alligators and Boas with which he engaged in combat; these are probably quite true, but those who know what a fat Boa or Python 12 or 14 feet long is like, will not think much of the feat of despatching it. Du Chaillu and other sensational authors have followed in his footsteps; the illustrations given by them of African Pythons are oll about a par with the well-known engraving representing a Boa, apparently 40 feet long, being ripped up by a negro while it is swinging from the branch of a tree. The present generation will not believe such exaggerations; for when the foot-rule is applied to the monster's in question they dwindle down to the ordinary size. Snakes from 10 to 14 feet long are considered very large now-a-days, and in former ages may have kept armies at bay, but our better acquaintanee with their habits enables us to treat them with the contempt they deserve. We remember a gallant Commander of the Royal Navy, who (taking a stroll after lunch at the back of a 
friend's garden in one of the suburbs of Sydney) observed a large Python or "Diamond Snake" basking in the sun. Ameriean and South Afriean travellers would probably have buekled on their armour and tried a shot at it from a safe distanee, but Captain $\mathrm{S}$. quietly eaught the reptile by the neek, and carried it to the Museum. On another oeeasion Captain P., formerly of the P. \& O. Serviee, brought a fine Python, 12 feet long, from Ceylorl, and terrible stories were told of how the reptile had devoured the ship's pet monkey, when it ventured too near its den. As it was intended for presentation to the Museum, one of the officers of that institution was dispatehed to take eharge of it. Armed with a bag, he arrived on board, listened to the stories of eaptain and erew, and-turned the snake out on deek; of course there was a general eommotion, the Lasears went aloft, and nobody would assist to hold open the bag, whieh, by the way, proved too small for the reptile; so a larger one had to be provided, and the snake was safely lodged therein without further assistanee or aeeident.

Günther states that Pythons ean swallow nothing larger than a half grown sheep, and that one of them, which lived for 15 years in the Zoologieal Soeiety's Menagerie, London, attained a length of about 10 feet in ten years, or 21 feet in all, it being 11 feet long when imported; but that afterwards no further growth could be observed in it.

Snakes feed mostly on living animals; a few only on eggs. The Blaek Snake (Pseudechis porphyriacus) will oeeasionally gorge itself with frogs or young water-rats, but attempt nothing larger. In a few instances it has come to the author's knowledge that one snake tried to swallow another of almost equal size; both were of a small species abont 18 inehes in length, and died in the struggle. The largest animal whieh a Carpet or Diamond Snake will eat is perhaps a Phalanger (or "Opossum"), a young Wallaby, Kangaroo Rat, or Bandieoot. It is generally believed that snakes drink a great deal, and that they will soon die if deprived of water ; but this is not the ease with Australian Snakes, whieh live for months without either food or water.

'The tongue of the snake is long and forked, and serves as a feelel' with whieh to examine objeets. Many persons, believing that wounds are inflieted by it, mistake it for a sting, and whenerer they see a snake thrust it out, immediately regard the reptile as a poisonous one. 
The tail of many Australian Snakes ends in a spine or sharp point, and in one species (the Death Adder, Acanthophis antarctica) the last seale is slightly curved, but almost always soft. Popular belief has invested this sluggish creature with the power of inflicting wounds with its tail; but this, like many other fables, is no longer entertained by persons conversant with Natural History.

It may be necessary to say a few words about malformations in Ophidians. These are generally restricted to a pair of heads on an ordinary body, and such specimens are met with in a very youthful state only. 'There arc several examples in the Museum collection.

The general habits of snakes will be found much alike in similar elimates, whether north or south of the line. Where frost occurs, all the reptiles retire under ground into the burrows of various animals; but in more genial regions, where the thermomcter seldom or never ranges below freezing point, they selcet sunny hill-sides abounding in flat stones through which the rays of the sun easily penetrate, and beneath them make their winter quarters. 'They do not fall into a dormant state, since bright, warm days will bring them out a few yards at least from their hiding-places. During this season it is easy to catch them by lifting these stones and transferring the prey into a bag, through which they never attempt to bitc. From six to ten specimens belonging to different species werc captured some years ago under a single stone not many miles from the city of Sydney; and to go "snake-hunting" has been a pastime here with school-boys for years. In some places, particularly on the north side of open stony ridges that are studded with low scrubby vegetation, and where grass-trees, zamias, and banksias abound, flat stones are laid about to scrve as traps during the winter, and are examined from time to time. In this way a great many reptiles are caught.

The collecting-bag often forms part of the outfit of our wallaby hunters, by whom the old sport of boyhood is not forgotten; and certainly there is considerable excitcment in lifting a rock or flat stone and finding beneath it handsome colored snakes, lizards, or frogs, which, being prevented by the cold from making a rapid escape, can be captured with ease. 
Thousands of snakes have been obtained in this way, presented to the Museum, and thenee transmitted to other institutions. The collectors have beeome interested in the pursuit, and are able at a glance to determine the character of their prey; and, happily, not the slightest accident has occurred to any of them during the course of eight years.

With the knowledge of these facts, timid persons may ease their minds, and rest assured that from May till September they will seldom encounter venomous reptiles in the scrub. The larger and more dangerous species, sueh as the Black Snake (Pseudechis porphyriacus), the Brown Snake (Diemenia superciliosa), the Brown-banded Snake (Hoplocephalus curtus), the Broad-scaled Snake (Hoplocephalus superbus), and the Death Adder (Acanthophis antarctica), always retire under ground, only a few young specimens being found under stones.

The geographical distribution of snakes is very extensivc. They inhabit almost every country from the south of Sweden and Siberia to Tasmania. None have as yet been reeorded from New Zealand; but they inhabit Ireland-a fact which is perhaps not generally known. India, America, and tropieal Afriea, appear to be the strongholds of the highly venomous speeies; and in these countries only the dangerons Rattlesnakes, Copper-hicads, Puff Adders, and Lanee-heads, are met with-all of which have very long movable fangs, and belong to genera which are not found in Australia.

Our Death Adder is the nearest approach to the Viper, but its fangs are permanently ereet, and its bite is not nearly so dangerons as that of the above-mentioned species.

The Death Adder is only found in the warmer parts of Australia, and not in Tasmania, Sonth Victoria, or' South-west Australia.

Only three speeies of snakes inhabit Tasmania, though foreign naturalists enumerate many more. Tasmanians distinguish the "Diamond Snake" (Hoplocephalus superbus), the "Carpet Snake," and "Black Snake" (Hoplocephalus curtus), and the "Whip Snake" (Hoplocephalus coronoides). 'The first is identical with the Continental Hoploceplualus superbus. The 
second two are varieties of eaeh other, the young brought forth differing greatly in colour even in the same litter. The dark variety has been described as Hoplocephalus fiscus by M. Steindachner; but Mr. George Masters captured a large number of both kinds of snakes in Tasmania, and took from a gravid female some thirty-five young, half of which were banded, and of a light eolour, and the rest black.

The third Tasmanian Snake is very small, only about 16 or 20 inches long, and, though venomous, not dangerous. This reptile is known as the Whip Snake (Hoplocephalus coronoides), and is allied to the New South Wales Blaek-bellied Snake (Hoplocephalus signatus), and to Masters' Snake (Hoplocephahus mastersii) of South Australia.

We do not know exactly how many snakes Victoria produces. In the south, the Tiger Snake (Hoplocephalus curtus) and the Tasmanian Diamond Snake (H. superbus) are met with; also the little Black-bellied Snake (Hoplocephalus signatus) and the Black Snake (Pseudechis porphyriccus). Near the New Soutl Wales boundary, on the Murray, we find in addition the Death Adder (Acanthophis antarctica), the Green-bellied or Grey Snake (Diemenia reticulata), the Brown Snake (Diemenia supercilios(1), and probably also the innocuous Green Tree Snake (Dendrophis punctulata), and the Carpet Snake (Moretia variegat(a).

There occur in South Australia, in addition to the above, sevcral small venomous Ophidians; the Death Adder is, however, very scarce, and, further west, altogether absent. Near King George's Sound are found many snakes of the brown-banded species, of a very marked colour, and with the bands much more distinct than in eastern speeimcns; small Hoplocephali, and particularly Hoplocephalus coronoicles, abound on the barren hills near the Sound, but of the Ophidio-fauna further to the northwest our knowledge is limitcd.

Returning to New South Wales, we observe, in addition to the speeimcus enumcrated from Vietoria, the Diamond Snake Mrorelia spilotes), and the Brown Tree Suake (Dipsas fusca), but miss the Tasmanian Diamond Snake (Hoplocephalus superbus). There is also a goodly number of small Ophidian reptiles, which will be fully described hereafter. Near the Queensland boundary, in the Clarenee and Rich- 
mond River District, a new form has been discovered which differs from other Australian renomous species in having scales strongly keeled; this species has been described as Tropidechis carinata. A small ringed snake with a very short head and tail, belonging to the South American genus Brachyurophis, is met with on the Clarence, as also are many other diminutive Ophidians which do not inhabit the southern districts. There the Diamond Snake disappears, and the sombre-coloured Carpet Snake takes its place, but no other Rock Snake is observed until the tropics are fairly entered.

Northern Queensland is rich in harmless Pythons; Nardoa gilbertii and Aspidiotes melanocephalus occur near Port Denison, and at the Gulf of Carpentaria two species of the genus Liasis have been observed. The harmless Fresh-water Snakes Cerberus australis and Ifyron richardsonii appear to be restricted in their habitat to the northern rivers.

A second harmless Tree Snake Dendrophis calligastra has lately been discorered near Cape York, and a variety of the Australian Brown Tree Snake Dipsas fusca extends even to New Ireland. This large island produces a second Tree Snake belonging to the genus Dendrophis, probably a new species, and a Python (Liasis amethystinus) which grows to a considerable size. The islands to the south-east of the Solomon Group are inhabited by harmless Pythons only. Enygrus bibronii is the most common of them, and found on the Solomon, New Hebrides, and Fiji Group, and the rarer Bolyeria multicarinata, which is generally but crroneously recorded by Foreign naturalists as inlabiting the shores of Port Jackson, must also be referred to the islands cast of New Guinea.

We believe that a small renomous snake allied to the Australian genus Diemenia is peculiar to Viti Levu, the principal island of the Fijis, but no large or dangerous venomous snake is on record from any other locality in the South Pacific. At New Caledonia no snakes have yet bcen noticed; they arc also absent from New Zealand, where a few lizards and frogs only represent the reptilia fauna.

Twenty-one innocuous and forty-two venomous Australian snakes have been described, but of the latter not more than five species are dangerous to man or the larger animals, and these retire under ground for nearly five months in the year. It is, of course, most desirable to distinguish the dangerous from the harmless species by external characters; 
and, by a little attention to the subject, this may be easily done. The following synopsis shews the distinguishing characters of-

a.-Non-Venomous SNakes.

Scales smooth, polished, not imbricated; without external eyes; tail $\left\{\begin{array}{c}\text { Blind Snakes. } \\ \text { Plate V, figs. 9, } 9 a \text {, }\end{array}\right.$ very short, ending in a sharp point $\quad \ldots \quad \ldots \quad \ldots \quad \ldots\left\{\begin{array}{c}10,11,12,12 a, \\ 12 b, 13,13 a\end{array}\right.$

$12 b, 13,13 a$.
Colubrides and

Gape of mouth deeply curved upwards, seven or more upper and $\left\{\begin{array}{c}\text { Colubrides and } \\ \text { Tree Snakes. }\end{array}\right.$ lower labials $\left\{\begin{array}{c}\text { Plate V, figs. 6, } 6 a \\ 7,7 a, 8,8 a\end{array}\right.$

Scales small, in more than thirty rows, more than ten labial scales (Pythons or bordering the mouth above and below; tail short and prehensile; $\{$ Rock Snakes. rudimentary limbs like spurs on each side of the rent ... ... Plate $T$, figs. 2, 3, Innocuous snakes when they bite leave marks thus$3 a, 4,5,5 a$.<smiles>C1CCC1</smiles>

b.-Venonous Strakes.

The gape of the mouth forming a straight line; with upper and lower labial shields six, and never more than seren in number; bodyscales in not more than twenty-six rows; larger teeth in front of the upper jaw covered by the gums Colubrine Snakes. Plates XI and Venomous snakes, when they bite, leave two punctures only, thus-

\section{$(\cdot \cdot)$}

An Australian snake that is not thicker than a man's little finger, whatever may be its length, cannot by its bite endanger the life of an adult human being.

Günther. states that "poisonous snakes are armed with a long canaliculated tooth in front of the upper jaw, with a duct which carries the poisonous fluid from a large gland to the tooth. This venom gland corresponds with the parotid salivary gland of the mammals, and is situated on the side of the head, above the angle of the mouth; it is invested by a dense fibrous sheath, which is covered by a layer of muscular fibres. At the moment the snake opens its mouth to bite, these muscles compress the gland, and force its contents through the excretory duct into the channel of the venom tooth, whence it is injected into the wound. The structure of the venom tooth is not the same in all poisonous snakes; in some it is fixed to the maxillary bone, which is as long, or nearly as long as in the non-venomous snakes, and generally bears one or more ordinary teeth on its hinder portion. The venom tooth is fixed more or less erect, is not very long, and its channel is gcnerally visible as an external groove. The poisonous snakes with this dentition, liave externally a more or less striking resenblance to the non-venomous ones; and on 
this account they are designated as Venomous Colubrine Snakes, and form the second suborder of snakes." All our Australian venomous serpents belong to this suborder (except the "Death Adder," Acanthophis antarctica, which occupies an intermediate position between the venomous colubrine snakes and the venomous snakes properly so callcd).

The third group or suborder is formed by those reptilcs which have an exceedingly long venom fang, with a perfcctly closed and externally invisible channel in its interior. The American Rattlesnake, the African Puff Adder, and other highly venomous serpents, may be mentioned as examples of this group. To give some idea of the relative size of the venom fangs in snakes of the third or viperine suborder, we refer to plate VI, fig. I, which represents the skull of the American Rattlesnake (Crotalus durissus), whilst fig. 2 represents that of the Australian Black Snake (Pseudechis porphyriacus). The fangs of the lattcr are scarcely large enough to penetrate common cloth or leather; they do not pierce ordinary bush boots, as has been frequently proved by cxperiment. If plate $V$, fig. I (the skull of the harmless Diamond Snake) be compared with the two previous figures, it will be seen at a glance where lies the difference between a venomous and a harmless serpent. The third suborder has no representatives in Australia. Owing to a limited power of locomotion, snakes are very much restricted in their habitat; and, though rich in the number of species, Australia has but few genera of Ophidian reptiles, when compared with other countrics in the same latitude. The four Blind Snakes, two Colubrides, two Fresh Water Snakes, and three Tree Snakes, belong to genera which are not peculiarly Australian; while the six species of Rock Snakes are not found beyond this region - that is, not in India or the islands of the Archipelago; 'Timor, New Ireland, and the Fiji Group, being the cxtreme northern limits of their geographical distribution. Twenty-three species constitute the whole of the Australian non-venomous snakes; and, not counting the Blind Snakes, we have but five harmless Ophidians in New South Wales. The second suborder, comprising the Venomous Colubrine Snakes, is, however, very large; and forty-two well-defined Australian species are known at present. Nearly all the larger kinds have the power of dilating the skin of the neck, and resemble in this respect the Hooded Snakes or "Najas" of India. The Brown-banded Snake (Hoplocephalus curtus), the Large-scaled Snake (Hoplocephalus superbus), the Black Snake (Pseudechis porphyriacus), and the Orange-bcllied Snakc (Pseudechis australis), bclong to this group, and 
are perhaps our most dangerous Ophidians. Two other large snakes-the Brown Snake (Diemenia superciliosa), and the Northern Banded Snake (Pseudonaja muchalis) -and all the small venomous but not dangerous species, do not distend their necks when angry, and probably bear a close resemblance to the Elapida of South America. The whole are peculiar to the Australian region, except the Short-tailed Snake (Brachyurophis australis), which, according to Günther, belongs to an American genus. The real position of the Death Adder (Acanthophis antarctica) has not yet been pointed out; in form a true viper, this snake has its poison fangs permanently erect, and will therefore be classified according to its dentition with the Elapida. From late experiments, it also appears that the venom of this reptile is less dangerous than that of the firstmentioned four species; thus, a Frog (Hyla aurea) and a young Sleeping Lizard (Cyclodus gigas), severely bitten by a Death Adder, lived for more than twelve hours after the bite. The snake was fresh, and very vigorous, and the fangs were left in the wound for two minutes.

We have already alluded to the nomenclature of foreign naturalists, who will persist in adding to our fauna reptiles which do not exist; the typical species of which (solitary specimens) are generally in the Paris Museum. Bolyeria multicarinata and Furina colonotos may be mentioned as examples. Their habitat is erroneously given as Port Jackson and Tasmania, though they have not been observed in these places before or since their alleged discovery by the French royagers during their very brief sojourn on these shores.

It will be necessary also to say a few words about the Sea Serpents which visit our coast, as they belong to the second suborder, and are frequently overlooked in adding up the Australian fauna.

Two well-known forms-the Ringed Sea Snake(Platurus laticaudatus) and the Yellow-bellied Sea Snake (Pelamis bicolor) - are occasionally thrown ashore on the coast of New South Wales; but eight other specics have been noticed further north, and these are fully described in Günther's great work "The Reptiles of British India," from which our figures and descriptions of them have been copied. Except the two common species, Sea Snakes are rare in collections; and in arranging the riches of the Australian Museum, one of these aquatic reptiles lias been found that cannot be classed with any other known form, and will constitute the type of a new genus. 
Nothing now remains but to give a few hints with regard to the names adopted by naturalists for the scales of the head and body in Ophidian reptiles; and for this purpose three woodcuts are added, to shew-

1st. The head from above, with nine scales, whereof

$r$ is the rostral shield

$f^{\prime}$ anterior frontals (2)

$f$ posterior frontals (2)

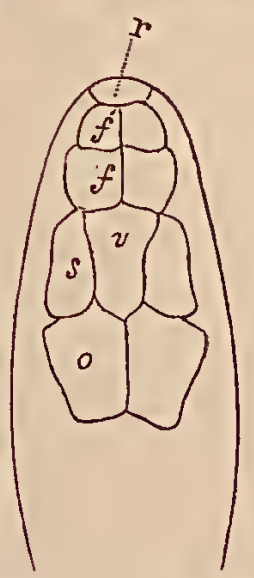

$v$ vertical

$s$ superciliary (one over each eye)

0 occipital (2)

2nd. A side view of the head of a (non-renomous) snake:-

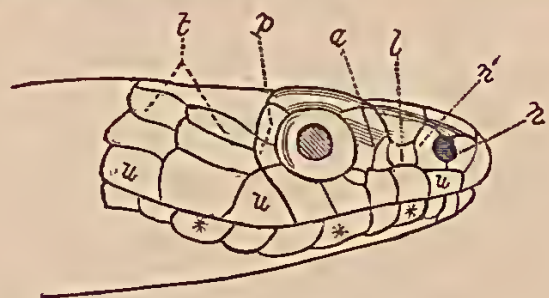

Shewing- $n^{\prime}$ and $n$ the nasals.

l. The loreal (absent in nearly all Australian renomous snakes).

a. Anterior ocular.

$p$. Posterior ocular (generally two behind each eye).

$t$. Temporals. Many venomous snakes have a large temporal shield wedged in between the two last upper labials, in such a manner as to give it the appearance of a labial shield.

u. Upper labials-There are generally six of these shields in venomous snakes (we may say always six, never more). Non-venomous serpents have seven or more.

* The lower labial shields, which correspond to those of the upper jaw, and are reduced to six in poisonous serpents. The labial shields have not been considered of much value in distinguishing one group from the other; but, after examination of many thousand specimens, it may be safely asserted that, by these shields alone can the harmless or venomous character of snakes be ascertained. This rule does not apply to Sea Snakes, nor to the Blind Snakes of the family Typhlopidce, but to Australianvenomous and innocuous colubrine snakes only. 
It must be borne in mind that we only deal with Australian snakes, not with American, African, or Asiatic species of the family Viperida, which have a large number of labial shields.

The Death Adder (Acanthophis antarctica)-intermediate between the Viperine and the Colubrine Venomous Snakes-has seven lower labials, but never more than six upper ones.

3rd view,-

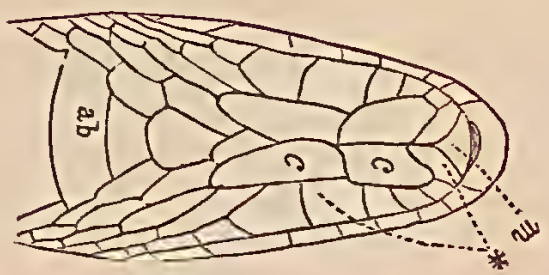

representing the head of a non-venomous snake from below, shewing $(\mathrm{m})$ the mental shield, $(c c c)$ the clin shields, (*) the lower labials, and $(a b)$ the abdominal or ventral plates. The two first shields do not enter much into the classification of Ophidians.

There are a few other expressions which it will be well to define. In mentioning the body scales, the word imbricate frequently occurs, by which it is implied that the scales overlay each other like the tiles of a roof.

The abdominal or ventral plates are counted from the chin shields to the vent, which is covered by one or two plates; below this the subcaudal plates commence, in one or two rows.

A few concluding remarks on snake poison, and the treatment of wounded persons, will perhaps be acceptable to many readers. A great deal has been written upon this subject of late, but with little benefit to the general public. The antidote vendors and their supporters have, however, been thoroughly exposed, and fresh experiments only prove that some animals will die in spite of every remedy, and others recover without physic.

Injections into the blood have been recommended, but ignorant persons wcre not cautioned against the danger of the experiment; and in the hands of the unskilled, the cure may prove to be worse than the disease. Doctors are not always present in places where dangerous snakes abound; it is necessary, therefore, to consider what should be done when a wound has been reccived by a person who cannot obtain scientific 
aid-and is perhaps without even water or a knife. The wholc treatment then resolves itself into this:-Suck the wound, if possible at once; apply a ligature; lacerate the punctures, and wash the part with water or urine; keep moving, and do not despond. Half the number of fatal cases have resulted from fear, many persons having dicd simply because they lost lieart, did not attempt to tie a ligature, or were afraid to lacerate the wound and suck it. There is generally no lack of courage in the inhabitants of the Australian bush, but it runs in the wrong channel, and often shows itself in chopping off the wounded toe or finger-a very foolisl and a very dangerous thing to do.

Prophets are seldom believed in their own country-let us see therefore what is recommended by Dr. Günther, F.R.S., the best known and the ablest of living herpetologists :-

"In ninety-nine out of a hundred cases, the wounds are inflicted on the hands or feet, and a ligature or two should be made, as tight as possible, at a short distance above the wound; the ligature to be left on until the proper means are provided to destroy the virus in the wound, and until medicine is taken internally, or until great pain or swelling necessitates its removal. The punctured wounds are to be enlarged by incisions at least as deep as the wounds, to cause a free efflux of the poisonied blood, and to facilitate its removal by sucking. The wounds to be sucked by the patient himself, or by another person whose mouth is free from wounds. Cupping-glasses will be found very useful. Ammonia should be rubbed into the wound, and be taken in large doses internally, from one to three wine-glasses of the eau de luce, or from one to six glasses of brandy at short intervals." And the learned Doctor thus concludes:- "In all accidents caused by bites of snakes, the action of the lieart is much affected; its contractions become feeble, the respiration difficult, and the patient feels great anguish, or sinks into a fainting state. To prevent a complete collapse it is necessary to use these strong excitants, and to repeat them until the alarming symptoms are allayed. It would be a great risk in such a case to trust to the remedies of a snake charmer."

In arguing about the value of certain remedies in cases of snake poisoning, it must not be forgotten that very few persons are able to classify these reptiles, and that when treatment has proved successful, there has not always been sufficient evidence to shew that the reptile 
that inflicted the bite was a dangerous one. In reporting their cases, parties interested are seldom able to give any information beyond the popular name by which a certain snake is known in the district in which they reside; and, as no general work on Australian Herpetology has yet been published, it is next to impossible, even for those who feel a great deal of interest in the matter, to master the often vexatious subject of snake classification.

We shall now proceed to enumerate the various species, and then give as many figures as possible, by means of which, and the descriptions, students of this branch of science will be better able than heretofore to form an opinion respecting venomous and harmless reptiles.

\section{FIRST SUBORDER.}

\section{INNOCUOUS SNAKES-OPHIDII COLUBRIFORMES.}

Snakes without grooved or perforated fang-like teeth in front.

Five families are represented in Australia.

1. BLIND-SNAKESTyphlopidx.

2. ColdrridesColubridæ.

3. Tree-STAKesDendrophidæ.

4. Nocturtati TreeSNAKESDipsadidæ.

5. ROCK-SNAKESPythonidx.
$\{$ Ventral scales not larger than those on the back; mental groove $\{$ none; upper labials four.

\{Body neither very slender nor compressed; no fang-like tooth $\{$ in front or in the middle of the upper jar.

\{ Body and tail much compressed or rery slender; head elongate; $\{$ eye large, pupil round; no fang-like tooth in front.

(Body and base of tail much compressed; head sub-triangular, broad behind, very distinct from neck, with short snout; eye very large, pupil elliptical, erect.

\{ Body cylindrical, flexible; anterior maxillary teeth unequal in $\{$ length, rudiments of hind limbs present. 


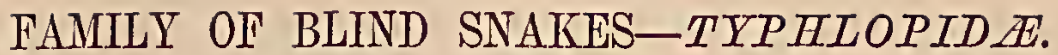

This family comprises those snakes which are known as Blind Worms; they have a cylindrical body, and a very short head and tail, the latter ending in a sharp point. The fore-part of the head is provided with large shields, covering the very rudimentary eye, which appears like a faint blue spot, and in some species is not visible at all.

Blind Snakes burrow in search of their food, which consists chiefly of ants and their eggs and larvæ. In excavating they are greatly assisted by their blunt heads, smooth scales, and short pointed tails. The posterior is generally larger than the anterior portion of their body. As far as can be ascertained, eight species of Australian Blind Snakes have been recorded, and descriptions and figures thereof published in works that are not all accessible to the author; it must therefore suffice to simply enumerate the various species, and add a few illustrations from the work of Professor Jan.

Typhlops (sp. Schneider) Dum.\& Bibr.

Snout covered with large shields; rostral large, rounded in front; præocular shield present; nostrils laterally in front of the snout.

SCHLEGEL's Blind SNaKe. Typhlops polygrammicus.

Typhlops polygrammicus, Schlegel, Abbild. unbek. Amph.

This species was first discovered at Timor, but subsequently found also in New South Wales. All the scales are brown, bordered with yellow.

Peters' Buind Snake. Typhlops bituberculatus.

Typhlops bituberculatus, Peters. Mlonatsber. Akad. Wiss. Berlin.

Professor Peters, of the Royal Museum at Berlin, has given a. description of this snake, which is said to inhabit South Australia.

GÜNTHER's BuIND SNaKe. Typhlops güntheri.

Typhlops güntheri, Peters. Mlonatsber. Akad. Wiss. Berlin, 1865, p. 259, fig. 1.

The same author has given an account of this reptile, which belongs to North Australia ; it was discovered by the late Mr. Elsey, who accompanied Gregory's Expedition as Surgeon and Naturalist. 
Gray's Blind Snake. Typhlops nigrescens.

(Plate $V$, figs. 12, 12a, 12b.)

Typhlops nigrescens, Gray, Cat. of Lizards in Col. Brit. Muss., p. 135.

Dr. J. E. Gray gives the following description of this species:-_ "Body slender, blackish; chin and under side white, the line of separation rather ragged; the dorsal scalcs pale cdged, especially on the front; head whitish in front, the head shields more or less clouded with grey in the centre; the rostral moderate, rounded above, rather curved on the sides; central crown-shields rhombic, as long as broad, the first the largest, the second and third of equal sizes ; tail short, and tapering, rather longer than wide, tip rather blunt, scarcely incurved." The typical specimen in the British Museum collection was found at Parramatta ; another example in Vienna was obtained by the naturalists of the "Novara," probably from the neighbourhood of Sydney. The last specimen measures 33 inches 5 lines, the tail being one inch long. The figures are considerably enlarged.

West Australian Blind Sxake. Typhlops australis.

Typhlops australis, Gray, Cat. of Lizards in Col. Brit. Arus.

Coloration a uniform pale yellow; rostral shield brown, nasal brown and rounded above; the central crown-shields nearly as long as broad, sixsided, the second (frontal) the smallest, the first and third nearly equal sized ; tail very short, about as long as wide.

Dr. Gray, from whose description the above notes are taken, mentions West Australia as the habitat of this species.

RüPPELl's BuINd SNake. Typhlops rïppelli.

(Plate $\mathrm{V}$, fig. 11.)

Typhlops rüppelli, Jan, Icon., libr. 9, pl. 1, f. 2.

Scales in 22 rows.

Total length, 22 inches.

Tail, 1 inch.

Rostral shield large and broad above, narrowing below ; preoculars much larger at the base than at the tip, third upper labial in contact with the ocular and preocular; anterior scales smaller than the posterior ones; tail short, cylindrical, very obtuse, three times the length of its diameter, and ending in a small spinc.

Coloration, brownish grcy above, and yellowish below; cach scale of the back being bordered with yellowish white, the markings becoming obsolete posteriorly. The form is cylindrical, enlarging towards the tail. Habitat, New South Wales. The typical specimens in the Frankfort Museum were obtained in the neighbourhood of Sydney. 


\section{Preiss' Buind Swake. Typhlops preissi. \\ (Plate $\mathrm{V}$, figs. 9, 9a.) \\ Typhlops preissi, Jan, Icon., libr. i, pl. V, fig. 2.}

Scales in 22 rows.

Tail, 5 lines, being as long as broad.

Total length, 17 inches 5 lines.

Coloration, grey above, lighter below. Habitat, South-eastern Australia. The typical specimen is in the Museum at Leyden.

Schurmt's Buind SNaKe. Typhlops bicolor.

(Plate V, figs. 10, 13, 13a.)

Typhlops bicolor, Schmidt, Peters, MIonatsber, der Berl. Akad., Wiss., 1860, pl. 81. Jan, Icon., libr. 4, pl. IV, V, f. 3.

Scales in 22 rows.

Total length, 27 inches 5 lines.

Tail, 8 lines.

Coloration, light brown above, yellowish white below. The typical specimen, obtained in the neighbourhood of Melbourne, is in the Hamburg Museum.

\section{FAMILY OF COLUBRIDES-COLUBRID $A$.}

The greater number of all the non-venomous snakes belongs to this family, but only two species are recorded from Australia; of these, one inhabits the far north, and is represented in the British Museum by a single individual. The Colubers do not show any peculiar distinguishing character's; they are generally of a moderate length, with a full rounded body, well-proportioned head, distinct from the neck, and have the cleft of the mouth in the form of a curve. The palate and jaws are well supplied with teeth, but no fangs are produced. 'The subcaudal plates are two-rowed.

\section{Coronella, sp., Laurenti.}

CORONFIIA.

Body cylindrical, not compressed, stout; head of moderate length, rather flat, and distinct from neek, with the snout rounded; tail of moderate length; eye moderately large, with round pupil. Rostral shield of normal size and form; two pairs of frontals; nostril between two nasals; one loreal, one anterior, and two or three posterior oculars. Scales smooth, in seventeen to twenty-three rows; subcaudals two-rowed. Posterior maxillary tooth longest, and in a continuous series with the anterior one. 


\section{Australian Ground SNake. Coronella australis.}

Coronella australis, Gnthr., Cat. of Colubr. Snakes, p. 40.

Scales in 17 rows; abdominal plates? two anal plates; subcaudal plates in two series? total length, $27 \frac{1}{2}$ inches; head, $\frac{3}{4}$ inch ; tail, 5 inches.

Above uniform olive, with a few black specks; beneath uniform whitish. Longer maxillary tooth not channeled. Body moderate, tail moderate, thin, distinct from trunk; head rather broad and obtuse; shields of crown regular, proportionate ; two nasals, one loreal, one anteorbital, raised on the surface of the head, but not reaching the vertical; two posterior oculars; eight upper labials, fourth and fifth narrow and coming into the orbit; one front temporal shield in contact with both postoculars; two others behind; first pair of lower labials forming a suture behind the terminal one. Scales moderate, rounded behind, in seventeen rows; anal bifid. Above nearly uniform olive, some scales with black tips or black tips and black edged; beneath uniformly yellowish. Longer maxillary teeth, not grooved, in a continuous row with the anterior ones. The typical specimen in the British Museum is described as above. The habitat given is "Australia," probably the far North; the snake must be very rare, as no other specimens have been discovered.

TROPIDONOTUS, Kuhl.

Body cylindrical ; head distinct from neck, flat; cleft of mouth wide; eye of moderate size, or rather large, with round pupil; nostril lateral, between two plates. Shields of the head regular; loreal always present. Scales keeled; ventrals rounded, considerably less than 200 in number; anal bifid; subcaudals two-rowed. Teeth numerous on the jaw and on the palate; the anterior in the jaws are always shortest; the posterior lengthened, but not grooved.

Australian Tropidonotus or Fresh Water Snake. Tropidonotus picturatus.

(Plate $V$, figs. 8 and 8a.)

Tropidonotus picturatus, Schleg. Ess., t. 12., f. 8, 9; Günther, Cat. Colubr. Snakes, p. 71.

Scales in 15 rows; abdominals, 157 to 160; two anal plates; subcaudals, $74 / 74$; total length, 2 to 3 feet.

Eight upper labials, the fourth and fifth touching the eye; one anterior, three posterior oculars. 
Ventral and sub-caudal plates margined with dark grey in some specimens; the back sometimes more or less marked with darker scales, forming a series of reticulated loops ; these markings occur in grey-colored subjects; in those of a brown color the marks are not visible.

The Australian Fresh-watcr Snake differs much at various seasons, and is either grey or of a rich brown color with salmon-tinted abdominal plates, which on the sides are generally red spotted ; there are fifteen rows of scales upon the back, each furnished with a raised keel, whilst the venomous Tropidechis, which resembles the harmless fresh-water snake, has more than twenty rows of very narrow elongate keeled scales on its body.

Port Essington and North-wrest Australia are given (by Günther) as the habitat of this snake, its most southern limit being, in all probability, the Clarence River. The Museum is in possession of specimens from almost every part of Eastern Australia north of the Clarence; and my excellent colleague, Mr. George Masters, informs me that, just at dusk, large numbers of these snakes were observed at lagoons or waterholes where he was encamped, not long ago, in the Wide Bay District; he never noticed them, however, during the middle of the day.

\section{FAMILY OF TRUE FRESH-WATER SNAKES-HOMALOPSIDAE.}

Body moderate, cylindrical or slightly compressed; head rather thick, broad, and not very distinct from neck; tail strong, of moderate length, tapering, more or less prehensile and compressed at its root, especially in the males. Ventral plates narrow, those beneath the tail two-rowed; eye small. The nostrils are situated anteriorly on the upper surface of the head, small, and provided with a valvule. Dr. Günther, from whose writings the above is abridged, mentions, with regard to the habits of these reptiles (which are not met with except in the far north of Tropical Australia), that they are thoroughly aquatic, and only occasionally found on the beach. In their organization they approach the true marine snakes, and are easily recognizable by the position of the nostrils on top of the snout, which enable them to breathe by raising a small part of the head out of water. The same arrangement is common to crocodiles, sea-snakes, and other aquatic animals. Many have a distinct prehensile tail, by 
means of which they hold on to projecting objects. Their food consists entirely of fish, and a few species use crustacea also. All of them appear to be viviparous, and perform the act of parturition in the water. They do not grow to any considerable size, are of gentle disposition, and their bite is by no means dangerous. They do not feed in captivity, and therefore die after a short time.

\section{CERBERUS, Cuvier.}

Head rather high, of moderate length and width ; body cylindrical, its hinder part and the tail rather compressed. Cleft of the mouth wide, turned upwards behind; eye, small, with vertical pupil; snout covered with shields, occiput with scales; nostril situated on the upper side of the head, between two nasals, the anterior of which is the larger, forming a suture with the corresponding nasal of the other side; two small triangular anterior frontals; eye surrounded by a ring of small orbitals, the superciliary being well developed; posterior upper labials divided transrersely into two. Scales keeled, in from twenty-one to twenty-five rows; ventrals of moderate width; anal bifid; subcaudals two-rowed. Maxillary teeth in a continuous series, slightly increasing in length posteriorly, the last being grooved. Mandibulary teeth, longest in front, decreasing in strength and more closely set behind. Viviparous.

\section{Australian Bockadair. Cerberus australis.}

Cerberus australis. Gray, Cat. of Snakes in B. MI., p. 65.

Slate-black in spirits; under lip and beneath white ; throat with two oblong black streaks; under side with two series of large, square, black spots, united by a rather broad black central streak; tail, black beneath.

The generic and specific characters are taken from Günther's and Gray's works. There are no specimens of this snake in the Museum. collection. The North Coast of New Holland and Port Essington are given as the habitat of this reptile.

\section{MYRON, Gray.}

The characters which distinguish this genus appear to be the same as those of "Cerberus." 
RichaRdson's Water SNake. Myron richardsonii.

Myron richardsonii. Gray, Cat. of Snakes in Col. B. MI., p. 70.

Scales keeled, black with alternate olive and many black cross bands ; sides white spotted; beneath white ventral shields dark edged with dusky central longitudinal streaks. A single reptile in the British Museum, obtained by $\mathrm{Sir}$ John Richardson on the North-west Coast of Australia.

\section{FAMILY OF DAY TREE SNAKES-DENDROPHID AE.}

This group of reptiles, like other non-venomous snakes, has few representatives in Australia; two species only have been discovered. They live in trees, and feed on frogs, lizards, young birds, and probably birds' eggs. The scales on the sides are generally narrow, with a row of larger scales on the back; the ventral plates have a sharp keel on each side, enabling the animal to climb with great facility. Australian Tree Snakes have teeth of equal size, the last tooth being the strongest of the series.

\section{DENDROPEIS, Boie.}

Body and tail very elongate, slender, compressed; head rather depressed, oblong, with the snout obtusely rounded in front. Eye rather large, with round pupil; nostril lateral, between two nasals; shields of the head regular; scales smooth in Australian specimens, in thirteen rows, and those of the vertebral series more or less enlarged; the other scales very imbricate and elongate, narrow, and quadrilateral; ventral shields keeled; anal bifid; posterior maxillary teeth not enlarged or grooved.

Greex Tree Snake. Dendrophis punctulata.

(Plates IV and $V$, figs. 6, 6a.)

Dendrophis punctulata. Gray, Gthr's. Cat. of Colubr. Snakes, B. ML., p. 119.

Scales in 12 or 13 rows.

Abdominals, 207 or more.

Two anal plates.

Subcaudals, 106/106 or more.

Total length, 5 to 6 feet.

Head, $1 \frac{1}{4}$ inch.

Tail, 14 inches. 
Habit moderately elongate and slender, belly flat, sharply keeled on the edges of the ventral scales; some portions of the skin between the scales white, others black, as may be best observed when the snake is angry, or, in preserved specimens, by stretching the skin. Olive-green, more or less bright above, beneath yellow, sides and chin of the same colour. The intensity of coloration depends a good deal upon circumstances. Gliding along the ground between tufts of grass in the sunshine, or swinging from branch to branch in lofty trees, the color of this snake appears to be dependent upon the surrounding foliage, as specimens in captivity never look so brilliant. The periodical change of the skin has also a good deal to do with the brightness of the snake's coat; and a few days before the skin is cast, all the lively hues have vanished, and a dull olive-brown is the prevailing color.

Young and half-grown Tree Snakes are olive-green above and light-brown below; if yellow tints are present, they appear near the neck and lower jaw. The eye is rather large, the gape curved, and the teeth small and of equal length. There is a row of scales running along the back much larger than the side scales, and polygonal in form; the outer rows are elongated, narrow, quadrilateral, and very imbricated; head shields regular; one anterior and two posterior oculars, and one loreal-a scale not often observed in venomous species. When angry, the body of this serpent expands in a vertical direction, whilst all venomous snakes flatten their necks horizontally. The Green Tree Snake, in a state of excitement, is strongly suggestive of one of the popular toys of childhood, by the peculiar white marks which become visible when its skin is distended.

Australian Tree Snakes are harmless creatures, and seldom offer to bite, even when handled; they live on frogs, lizards, young birds, and perhaps on insects and eggs also; they are probably oviparous; their length seldom, if ever, exceeds six feet.

The geographical range of the present species appears to be very wide, and the whole of Australia, except the southern portions of Victoria, may be considcred its habitat. No spccimens have as yet becn captured in South or South-western Australia; the snake may exist therc, lowever, but it is doubtful whether $D$. punctulata is found in the Phillipine Islands, or in Ccylon, from which localities specimens are on record in the British Muscum Catalogue. 
Northern Tree Sxake. Dendrophis calligastra.

Dendrophis calligastra, Günther, Ann. and MIag. Nat. Hist., vol. 20 (Third Series), p. 53.

Scales in 13 rows.

Abdominals, 179.

Two anal plates.

Subcaudals?

Total length, 36 inches.

Tail, 12 inches.

No loreal shield; eight upper labials, the fourth and fifth entering: the orbit; one antcrior and two posterior oculars; temporal scales, $1+2$ +2 ; abdominal shields strongly keeled, some of the scales with a single terminal pore; greenish brown above, sides of the head and neck yellow; a black band across the rostral shield through the eye to the side of the neck; belly purplish yellow, powdered with purplish brown.

Habitat, Cape York.

\section{FAMILY OF NIGH'T TREE SNAKES-DIPSADIDAE.}

The Nocturnal Tree Snakes inhabit Asia and the islands of the Indian Archipelago, as well as Africa, America, and Australia.

India, which is their stronghold, produces ten species, Africa a few, and America and Australia one kind each. The islands in the ncighbourhood of New Guinea are inhabited by another species which is closely allied to our Australian Dipsas fusca.

Dipsas, auct.

\section{DIPSAS.}

Body and tail much elongate and compressed; head depressed, triangular, short, broad behind, very distinct from neck; snout short; cye rather large, with vertical pupil ; nostril between two nasals; shields of the head regular; loreal present; scales smooth, more or less narrow on the sides, those of the vertebral series dilated; anal entirc; subcaudals two-rowed; posterior maxillary tooth grooved. 
Brown Tree Snake. Dipas fusca.

(Plate V, figs. 7, 7a.)

Dipsas fusca, Gray, Günther's, Cat. of Snakes in Col. Brit. IIus., p. I71.

Triglyphodon flavescens, Dum. and Bibr., p. 1080.

Scales in 19 rows.

Anal entire.

Abdominals, 236.

Subcaudals, $87 / 87$.

Total length, 6 to 7 feet.

Head, $1 \frac{1}{2}$ inch.

Tail, 13 inches.

Form slender; body and tail compressed and elongate; head much depressed, triangular, broad behind, and very distinct from neck; scales on the vertebral line much larger, regularly six-sided, vertical shield broad, occipitals obtuse behind, one loreal; eight upper labials, the third and fourth and sometimes the fifth touching the orbit; one anterior two pos. terior oculars; eye large, pupil elliptical ; nostril moderate, between two shields; posterior maxillary teeth longest and grooved.

Above, light or reddish brown, with numerous black, rather oblique, and sometimes obsolete, cross bands; belly uniformly salmon-colored.

This species has not been so much noticed in the neighbourhood of Sydney as the Green Tree Snake, but this may be owing to its nocturnal habits; it is found along the East Coast, and ranges as far as Port Essington ; individuals, observed in captivity, appeared very gentle in disposition, and could be freely handled without showing any inclination to bite; they passed the day coiled up amongst the branches of trees, but became very active at night, noiselessly gliding through the foliage in search of their prey, which, as with the Green Tree Snake, consists of birds, birds' eggs, insects, frogs, lizards, and the smaller' mammalia.

Günther states that all Indian Dipsades live on warm-blooded animals, some preying on birds, some on mammals only; it must be supposed, however, that when young they feed on frogs and lizards also.

In this reptile the posterior maxillary tooth is grooved, but its bite is not the least dangerous. 


\section{FAMILY OF ROCK SNAKES-PYTHONID E.}

The Australian Rock Snakes are rather more numerous in genera than other non-renomous tribes inhabiting this country, and, excepting the Bolyeria multicarinata, * six more or less distinct species of them have been observed.

The largest snakes belong to this family, and individuals of great length occur, some measuring as much as ten feet, and perhaps more.

The body is muscular, more or less compressed in young individuals ; tail prehensile, with a pair of spurs representing rudimentary limbs at its root, which are often hidden beneath the scales. The head is elongate, flat, and covered with many irregular small plates; if any regular plates are present, they never reach further than to between the eyes. The scales are smooth, and the rows they form around the body far more numerous than in any other tribe of Ophidians inhabiting Australia, so that by the large number of scales alone their harmless nature may be ascertained. The pupil is vertical, but dilates at night or in the dark; in fact, all our Pythons are Night Snakes, and when observed in the day-time moving about it is generally because they have been disturbed. The teeth are numerous in botll jaws ; they feed on the smaller mammals, birds, \&c., which they kill by pressure ; they lay eggs, and incubate them.

Pythons are found on the Indian Continent and the islands of the Archipelago, in Africa and Australia. The American Boas form a different family.

The way in which these snakes attack their prey is very simple. Coiled on the branch of a trce, the reptile moves only the head and part of the body, advancing and retreating - in fact, measuring its distance with head and neck bent into the form of a horizontal S. When pretty sure of its aim, the snake darts forward with open jaws, fastens upon the victim, and in an instant brings it within a loop formed by a portion of the body, which gradually tightens till the prey is suffocated. In this position the suake will remain for twenty minutes or half an hour, holding the body of the animal tightly; it then gradually uncoils, and, if inclined to fecd, begins the process of swallowing with the head.

* This species is mentioned erroneously as inhabiting the neighbourhood of Port Jackson. 
The great quantity of saliva discharged by the snake over the body of the quarry preparatory to swallowing it, as described by other writers, has not been noticed in the case of our Rock Snakes-the Diamond and the Carpet Snake. Yet, when a carcass just devoured by one of them is, for some reason or other, disgorged, it is occasionally found covered with mucus evidently applied to it in its passage downwards. These rejected bodies are likewise found to be stretched to an extraordinary degree by the continual workings of the powerful muscles of the snake while engaged in the swallowing process.

Rock Snakes attain a great age, but cease to grow after a certain period. A Python eleven feet long would be about four years old (Vide Bibron's Observations on the young Pythons in the Garden of Plants at Paris), and they grow much quicker in the first period of life than afterwards. The males remain smaller than the females. These facts, stated by authorities like Günther and Bibron, are borne out by observations made on Australian Rock Snakes, which, when born, are less than half the size of young Indian Pythons; and a Diamond or Carpet Snake which measures above 10 feet in length may be more than twenty years old. Though little or no addition to the length of these large snakes is observed, it is most likely that they increase in girth. It has already been mentioned that Rock Snakes lay eggs, which the mother incubates; and, that Australian Rock Snakes are no exception to this rule, is proved by Mr. W. Allan, of Kimbriki, on the Manning River, who a few years ago presented to this Museum a drawing of a heap of eggs of the Diamond or Carpet Snake, neatly piled up in a sort of nest of dry grass which was found in a hollow branch or log. Günther mentions that a pair of Pythons copulated in January and February, the female producing fifteen eggs, the size of goose eggs, in May; and that having collected them in a conical licap, she entirely covered thcm by coiling herself round them spirally till her head rested in the centre on the top of the cone. In this position she remained till the 3rd of July, when eight of the eggs were hatched. Similar facts have been noticed in reference to another species from Africa; and, though Mr. Allan who made the observation did not actually see the snake upon the eggs that he found, it may be fairly concluded that Australian Pythons do not differ in this respect from their congenera in Asia and Africa. 
Dr. Günther observed an increase of tempcrature between the coils of the snakes incubating in the Gardens of the Zoological Society of London; and he draws the conclusion that a higher degree of warmth is necessary for the development of cmbryonic Pythons than for other snakes.

MOREIIA, Gray.

Head shields small, scale-like; frontal plates distinct, three pair's; vertical plate small; rostral shield single, with a pit on cach sidc; three front upper, and the hinder lower labials pitted; nostrils lateral, in a single plate, with a groove bencath; eyes lateral, pupil elliptical, erect; scales, small, smooth; subcaudals two-rowed.

Diamoxd Sxake. Morelia spilotes.

(Plates I and V, figs. 1, 2.)

Morelia spilotes, Gray. Cat. of the Specimens of Snakes in Col. Brit. Arus., p. S5.

Scales in 47 rows.

Abdominals, 270.

Two anal plates.

Subcaudals, 80/80.

Total length, 8 to 10 feet.

Head, 4 inches.

Tail, 15 inches.

One of the characteristics by which harmless Rock Snakes may be at once distinguished from poisonous serpents, is the large number of scales covering their body; at present but one venomous species is known to have as many as twenty-six rows of scales, whilst Pythons or Rock Snakes have double that number.

The Diamond Snake has the body scales in 47 rows, with about 276 to 300 ventral plates, and the scales under the tail divided into $80 / 80$ or $90 / 90$ or more. The subcaudal plates vary in almost erery individual, as the much-used prehensile tail is liable to be injured or broken, and is not in the latter case reproduced like the tail of lizards. The general colour of the Diamond Snake is a kind of bluish-black, very glossy when the skin is fresh, and the epidermis lately shed, but becoming duller after the wear and tear of a few months, and quite opaque just before the skin-shedding process begins. As a rule, Diamond Snakes 
have almost every scale of the body marked with a yellow spot in the centre, and often a somewhat indistinct, and frequently interrupted, yellow streak on each side. The abdominal plates are yellow, more or less blotched with black; and many species occur which have a number of diamond-shaped yellow spots upon the body, formed by a few of the lighter scales, and hence their name has probably arisen.* The head is covered with a number of irregular small scales, which are also more or less marked with yellow, and the last seven scales of the lower jaw forming the line of the month are deeply pitted. By these grooved or hollowed scales the harmless character of the reptile may be at once ascertained, as not one of our venomous species has scales so marked. The line of the mouth-the "gape"-is straight, as in renomous subjects; but the deep indentions which mark the last lower labial scales, the small irregular head shields, the numerous body scales, the prehensile tail, and the rudimentary limbs or spur's near the anus, can leave no doubt on the minds of persons who know these facts as to what kind of reptile they have to deal with should they be wounded by a Diamond Snake.

It must not be overlooked, however, that in Tasmania a highy venomous specics (Hoplocephalus superbus) has also received the name of "Diamond Snake;" and it is often the case that persons who have for some time resided in Tasmania describe "Diamond Snakes" indiscriminately as highly venomous. To make a work of the present kind useful to all, co-operation is necessary ; and as a good sound English name is prefixed to every species, it is to be hoped that such name will, if possible, be retained, and that Tasmanian friends will accept another designation for the renomons "Diamond Snake" of their island, namely,-Broad-scaled Snake (Hoplocephalus superbus).

The range of this reptile (II. spilotes) is restricted to a very limited area of country, it being found in no other part of Australia than from Port Macquarie to Jervis Bay or perhaps Cape Howe, and from the coast to the western slopes of the Bluc Mountains and the Liverpool Range. In the plains watered by the Lachlan, the Murray, and the Murrumbidgee, this species is not found, the Carpet Snake (Morelia variegata) there taking its place.

* A rery fine Diamond Snake, with the yellow spots rery large, ind with numerous regular eross bands, has been receired at the Museum from Brisbane Water; it measures 8 feet 6 inehes in length. 
The Diamond Snake is common in the county of Cumberland, in the Blue Mountains, and in the Illawarra district; though a harmless creature, when it is irritated its bite is severe; and though strictly nocturnal, individuals are sometimes met with during the day-time, either basking in the sun and digesting their food, or in search of a place of shelter when they have been disturbed. Like the other members of the family Pythonida, they prey upon birds and the smaller mammals; young individuals feed upon insects, frogs, or birds' eggs; in January or December the female deposits thirty eggs or more, which she incubates.

Diamond Snakes are found in almost every kind of country that offers them sufficient shelter. They prefer open stony ridges, studded with low trees, and well supplied with water; but frequent the edges of swamps and lagoons, where they find a good supply of Water Rats (Hydromys), besides young ducks, and other water-fowl ; they also often visit the henroosts of the farmer, or surprise the smaller mammals upon the branches of. trees.

The largest specimen captured near Sydney, correctly measured, without being stretched, was 10 feet 3 inches long; individuals of 11 feet or more in length occur no doubt, but they are very rare indeed, and have never been preserved in collections.

In a state of nature they never touch any food except living animals. Once, however, a Diamond Snake, which was kept in a cage, swallowed a rat which had been killed by a Brown-banded snake (Hoplocephalus curtus).

The species under review are greatly infested by various kiuds of intestinal worms, including a tape-worm, clusters of which have frequently been taken from their stomachs.

\section{CaRPet SNake. Morelia variegata.}

(Plate II.)

Morelia variegata, Gray, Cat. of Spec. of Snakes in Col. B. MI., p. S6.

Whether the Carpet Snake is only a variety of the former species, or whether it deserves to be classed as a separate kind, has not been satisfactorily proved; and as both snakes are totally distinct in color, and very restricted in their habitat, it will perhaps be better to speak of them here as two species.

The general structure of the scales of the head and body is precisely alike in both reptiles, but they vary much in coloration. 
We have noticed before, that the Diamond Snake is of a glossy black, with a bright yellow spot in the centre of almost every seale, and with belly-plates of bright yellow, clouded with black.

The Carpet Snake is uniformly greenish-brown, with darker irregular spots, enclosed by a still darker margin of about a scale wide, covering the body from the head to the root of the tail. The belly is pale straw colored, and the plates often spotted or margined with a neutral tint.

There is much variety in the marking of different individuals, but the greater number have a pale, and sometimes interrupted and darker bordered streak on each sidc of the body, running from the neek to the vent.

The ground color in old snakes is muelı darker than in young ones.

Spirit specimens frequently turn quite white, the blotches appearing dark grey, or pale black.

If the Carpet and Diamond Snake are really one and the same species, it is very curious to notice that they have so very defined a habitat. It was mentioned before, that Diamond Snakes were only found in a very limited district on the New South Wales coast, whilst Carpet Snakes occur in every other part of Australia except the said district, and in Southern Victoria.

In their movements, and the way in which they obtain, kill, and devour their food, both species are so precisely similar, that further remarks on these particulars are unnecessary. With regard to their size, there is reason to believe that Carpet Snakes attain even larger growth than Diamond Snakes, and the Museum has lately received from Capt. Harley, of the steamer "Havilah," a very fine specimen measuring 8 feet in length. This snake was taken at Cleveland Bay, and is of the same size as the monster Diamond Snake captured near the Point Piper Road, in the most fashionable suburb of Sydney, by Capt. Stackhouse, R.N., in July, 1868.

It is possible that many larger snakes have been killcd, but they are generally measured by the cye only, and we all know how apt one is to cxaggerate the size of such quarry; there is nothing so good as a tapeline, if truth is to be asccrtained; but people do not generally care to be very particular, and after relating snake stories for years they make the size of the reptile increase as their story grows old. 


\section{A.SPIDIOTES, Freft.}

Crown eovered with broad shields, reaching behind the eyes; the remaining part of the head sealy; labial shields without pits, the front ones high and narrow, the hinder ones lower and broad. Nostrils lateral, in the middle of a plate; two loreals; two anterior and four posterior oculars; superciliaries broad, rather prominent above the eye; nasal shield very large, mueh produeed baekwards, and deeply grooved on its lower edge. Scales smooth, in fifty-two series on the middle of the body; ventral plates rather narrow; subeaudals entire, exeept the last ten or twelve whieh are divided. Tail eonieal, prehensile, ending in a blunt point. Head rather high, of moderate size; teeth not very large (smaller than in Morelia). Body thiek and eompressed.

Black-headed Snake. Aspidiotes melanocephalus.

(Plate III and Plate V, fig. 4.)

Aspidiotes melanocephalus, Krefft. Proc. Zool. Soc., July 28th, 1864.

Scales in 52 rows.

Abdominals, 330 .

One anal plate.

Subeaudals, $511^{\frac{13}{3}}$.

Total length, 8 feet or more.

Head, 3 inches.

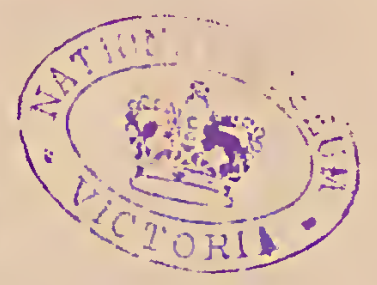

Tail, 12 inches.

Head rather high; body thick and eompressed; tail eonieal, tapering, prehensile, ending in a blunt point; anal spurs small; ten upper labials, the sixth eoming into the orbit; two anterior and four posterior oeular shields; two loreals, the second nearest to the eye very small; one nasal, pierced by the nostril; eye moderate, pupil elliptical, erect. Three pairs of frontal shields, the middle pair longest; vertieal broad, the largest shield of the head, with an obtuse angle in front and an aeute one behind; sides rounded; supereiliaries large, and prominent above the eyes; oeeipitals distinet, but smaller than the rertieal ones, and forked and rounded behind; the first pair of frontals small, and triangular; the seeond pair five-sided, and nearly as large again as the first; the third smaller than the seeond larger than the first, and quadrangular. Of the fourteen lower labial shields, the first seven are narrow and elongate, the rest broad; no groove upon 
the labials. The nasal shield is very broad, with a deep pit, shaped like a bean, and much produced backwards. Head moderate; body thick, compressed; anal spurs small. Color light brown, with a series of darker rings, which become indistinct near the sides; below yellowishwhite here and there, with a few dark blotches; head and neck jet-black above and below. Total length, $7^{\prime} 10^{\prime \prime}$.

This reptile is probably as large, if not larger, than the Rock Snakes of New South Wales, but at present little or nothing is known about it. The first specimen which the Museum received was captured by Mr. Rain. bird, the well-known collector at Port Denison; it was met with subsequently on the Burdekin, at Cleveland Bay, and Cape York.

It may be distinguished at once by the jet-black head and neck. The scales are smaller than those of the Diamond or Carpet Snake, in fifty-two rows, and the belly plates very narrow, more than 300 from neck to vent. Northern settlers will bear in mind that venomous snakes have generally from fifteen to twenty-six rows of scales only, so that by counting the number of scales the harmless nature of some snakes may be ascertained.

\section{IIASIS, Gray.}

Head scaly, with symmetrical shields on the muzzle to between the eyes; vertical plate single; nostrils lateral, in a single shield, with a groove behind; eyes lateral ; pupil oblong, erect ; upper and lower labial shiclds pitted; scales smooth; subcaudal plates two-rowed.

\section{Children's Rock Snake. Liasis childrenii.}

Liasis childrenii, Gray, Cat. of Snakes in Col. B. MI., p. 92.

There are but few Australian snakes not represented in the Sydney Museum, and this species is one of them. It has the first three or four of the upper lip-shields pitted, and four of the plates on the lower jaw (those preceding the last three) indented in the same manner.

In Dr. J. E. Gray's Catalogue of Snakes the color is described as purplish brown; back with a central series of oblong, transverse, dark spots; sides with two series of roundish black spots, beneath white; upper lip with a dark streak to the angle of the mouth. 
The genus Liasis is distributed over some of the islands of the Arafura Sea, as Timor, and the Aru Group; a species also inhabits New Ireland (Liasis amethystinus), which is figured at Plate V, figs. 5 and $5 a$, so as to give some idea of the character of this reptile, there being no Australian species in the Museum collection.*

\section{OLIVE-GREen Rock SNAKE. Liasis olivacea.}

Liasis olivacea, Gray, Cat. of Snakes in Col. B. II., p. 92.

A second Rock Snake of the genus Liasis occurs near Port Essington, and on Sir Charles Hardy's Island, of which Dr. Gray gives the following brief description :-

"One preocular and three postocular shields; rostral not pitted; the first pair of upper labials with a small pit on the outer upper edge; the four or five hinder pair of the lower, preceding the three last, pitted. Pale olive-green (in spirits); upper lip and beneath pale yellowish; occiput scaly, with one pair of larger shields."

\section{INARDOA, Gray.}

Head scaly ; muzzle regularly shielded to between the eyes; nostrils lateral, in a single plate; eyes lateral; pupil elliptical, erect; upper labial shields flat; hinder lower labials pitted; scales smooth; subcaudal plates two-rowed.

GLubert's Rock SNake. Nardoa gilbertii.

(Plate V, figs. 3, 3a.)

Nardoa gilbertii, Gray, Cat. of Spec. of Snakes in Col. B. ML., p. 93.

Scales, 52 rows.

Abdominal plates, 330 .

One anal plate.

Subcaudals, $51^{\frac{13}{13}}$.

Total length, 42 inches.

IIead, $1 \frac{1}{4}$ inch.

Tail, 4 inches.

* The Trustees are since indebted to Capt. M'Gregor, of the yacht "Chance," for a splendid collection of New Ireland Reptiles, among which is a large Liasis amethystinus. 
"Pale (in spirits). Back with five longitudinal series of dark olire spots, which are more or less confluent, forming cross bands, closer together on the hinder part of the body, appearing olive with irregular whitish lines; head with a black streak above the lip, through the eye, to the side of the neck; head-shields brown, with a black spot; loreal shield square; anterior ocular large; posterior oculars 3, small; interloreal scales 2 , small. The front of the body has a narrow longitudinal streak on each side, between the spots."-Gray's Description of the Brit. Mus. Specimens.

The few specimens in the Museum collection are the gift of William Macleay, Esq., F.L.S., who obtained them from Port Denison. The general form is shorter and thicker than the Rock Snakes treated of before, and in all probability the size of old individuals does not exceed 5 or 6 feet. The ground color is a pale olive or brown, with five rows of irregular brown or black spots from the head to the tip of the tail, beneath it is pale straw yellow. The head is regularly shielded to between the eyes, and three of the hinder shields and the lower lip are pitted. The tail is very short, the plates and the under side of it forming partly two rows, with a dark central streak from the vent to the tip. Head-shields with a few black spots and margins; eye of moderate size, with elliptical and erect pupil; a dark streak runs from behind the eye to the nostril. About the habitat of this reptile little is known, beyond the donor's statement that it was obtained at Port Denison.**

* Captain Edwards, of the schooncr "Mrelania" (who has always been a liberal donor to the Minseum), obtained a species of Nardoa on Sweer's Island in the Gulf of Carpentaria. This snake differs from N. gilbertii in having a shorter and thicker head, a more elongate rertical shield, and the last pair of frontals largest; the color is a dull olive-brown, the dark spots very indistinct, and not conflucnt posteriorly; no black marks can be traced on the head, exeept the temporal streak behind the cye.

Captain Edwards has promised to supply the Trustees with more specimens, when the question whether this snake is new or not will be decided. 


\section{SECOND SUBORDER.}

\section{VENOMOUS COLUBRINE SNAKES.}

(OPHIDII COLUBRIFORMES VENENOSI.)

Snakes with an erect immovable grooved or perforated fang in front of the maxillary.

Two families inhabit Australia-

1. Etapid $\operatorname{lllll} \quad \ldots \quad \ldots \quad \ldots \quad$ Tail conical, tapering.

2. HYDROPHID玉... $\quad \ldots \quad \ldots \quad \ldots$ Tail strongly compressed, paddle-shaped.

\section{FAMILY OF ELAPIDES-ELAPID}

Body cylindrical or subcylindrical, tail rather short, tapering; head with the normal number of shields above; no loreal, except in one species; eye not very large, pupil rounded or elliptical. The venom fang shows a distinct groove along its front, and the interior canal terminates in a slit at the extremity.

The snakes of this family inhabit all the tropical regions, but principally Australia, the island of Tasmania being their most southern limit.

Some of these reptiles, such as the deadly Brown-banded Snake (Hoplocephalus curtus), the Broad-scaled Snake (Hoplocephalus superbus), and the Black Snake (Pseudechis porphyriacus), have the power to dilate the skin in the neck, and are related to the Cobras of India; others, such as the Black-and-white-ringed Snake (Vermicella occipitalis), are allied to South American genera. We shall not attempt to make any subdivision, but enumerate the various species according to Günther's Catalogue of Snakes in the Britisl Museum, including the Death Adder in this family. 


\section{DIFMEIN IA,* Gray.}

Body and tail moderate or slender, rounded; head high, quadrangular, with rather short rounded muzzle; rostral moderate, vertical, narrow; no loreal, which is replaced by the conjunction of posterior frontal (bent down on the sides), of anterior ocular, of second (triangular) upper labial, and of posterior nasal ; one anterior, two posterior oculars; two nasals, nostrils between; scales smooth, not much imbricated, in fifteen or seventeen rows; anal bifid; subcaudals two-rowed; groored fang in front, a series of smaller equal teeth behind.

\section{Schlegel's SNake. Diemenia psammophis.}

Elaps psammophis, Schlegel, Ess. II, p. 45, and Abbild., t. 46, fig. 14. Pseudoëlaps psammophidius, Dum. \& Bibr., p. 1234. Diemansia (Diemenia) psammophis, Gnthr., Cat. of Colubr. Snakes in Col. Brit. Alus., p. 212.

Scales in 15 rows.

Two anal plates.

Abdominals, 223.

Subcaudals, 97/97.

Total length, 6 feet 7 inches.

Head, 1 $\frac{1}{2}$ inch.

Tail, 16 inches.

Body elongate and slender; head shields very elongate, vertical broad anteriorly, becoming narrow towards behind; eye large, pupil rounded; preocular shield deeply grooved, also a groove on the lower edge of the rostral shield, six upper and lower labials with a large temporal shield between the two last of the upper series. General colour brown above; sides and abdominal plates of the anterior half of the body bluish grey, the abdominals somewhat lighter in the centre; all the upper scales on this part red-edged; the posterior part much lighter in colour, and the scales dimly margined with bluish grey, the marking appearing very prominent wherever a portion of the epidermis has been remored; the abdominal plates assume a yellow hue, are at first powdered or clouded with black, and become clearer towards the tail, which from the rent to the tip is pale straw yellow. Dr. Gray's short description is as follows:" Elabit very slender; forehead very convex. Above nearly greenish olive; rostral shield without cross streak."

* This is the correct spelling of the word, which evidently has been derived from Van Diemen ('s Land). Originally written Demansia by Dr. Gray, it has since been altered into Dicmansia by myself (Colubr. Suakes, p. 254), and into Diemennia by the Editor of the Proceedings of the Zoological Socicty (1863). (Günther.) 
The figure referred to in Schlegel's Abbildungen, t. 46, f. 14, represents the head of the snake generally known as Diemenia reticulata (Plate XII, fig. 10). In the British Museum Catalogue the habitat of this snake (H. psammophis) is given as Port Essington and North Australia. Our Museum specimens were collected at Port Denison.

Spotted-meaded Snake. Diemenia olivacea.

(Plate VI, figs. 9 and 9a.)

Demansia olivacea, Gray, Zool. Mis., p. 51, Demansia (Diemenia) olivacea, Gnthr., Cat. of Colubr. Snakes in Col. Brit. Mrus., p. 212.

Dr. Gray's description is condensed thus:- "Habit moderate; olive green, skin between the scales black; scales of the sides with two white streaks at the base; a dark streak from the back edge of the eye to the angle of the mouth."

The reptile figured, which is in all probability identical with Gray's typical specimen, may be described as follows:-

Scales in 15 rows.

Two anal plates.

Abdominal plates, 180.

Subcaudal plates, 85/85.

Total length, 44 inches.

Head, $1 \frac{1}{4}$ inch.

Tail, 10 inches.

The general colour above is a dark olive green, or rather a rich brown with a greenish tinge, much darker posteriorly, the tail in particular, which towards the tip is salmon-coloured. The two white streaks at the base of each scale, which Gray mentions, are best seen when the epidermis is removed, or perhaps in living specimens when the skin is stretched, which is otherwise black between the scales. There are black spots on the hinder upper labials, which, in some specimens, may form a streak; in young and half-grown subjects the inner margin of the ocular shields is yellow; the anterior ocular being (as is usual in the members of this genus), deeply indented. The head-shields are more or less black-spotted, but not always very regular' chin and neck pale yellow below, the first 8 or 10 abdominal plates sometimes with a sharply defined black margin, which gradually becomes interrupted in the centre, and about the middle of the body is altogether obsolete. In some examples the abdominal plates are 
uniformly dark (rather bluish) grey, and much lighter anteriorly; in others all the plates are clouded with bluish black, occasionally formed into blotches, and leaving irregular yellowish portions in the middle of each plate. The body scales on back and sides are dark throughout, those only on the anterior half of the body shewing a margin with a black dot at the tip of each scale. The few specimens in the Museum eollection present a variation in color, sufficiently great to have warranted the creation of a new species, but after all they are probably the same snakes which Dr. Gray had under consideration when describing $D$. olivacea.

The British Museum examples are from Nortli-east Australia and Port Essington; those in the Australian Museum, from Port Denison.

\section{Grey Srake. Diemenia reticulata.}

(Plate XII, fig. 10.)

Diemenia reticulata, Gray, Zool. AFisc., p. 54. Gntler., Cat. of Colubr. Snakes in Col. B. $M I .$, p. 212.

Elaps psammophis, Schlegel, Ess. II, p. 455, and Abbildg., t. 46, f. 14.

Scales in 15 rows.

Two anal plates.

Abdominals, 177.

Subcaudals, 85/85.

Total length, 30 inches.

Head, $\frac{1}{2}$ inch.

Tail, 6 inches.

The coloration is uniformly grey above and greenish below, the central part of the ventrals being conspicuously marked with green; tips of scales and skin between them black; end of tail, salmon-colored, a yellowish dark-edged streak crossing the rostral shield. The eye is encircled first by a black and then by a yellowish line, both ending in a point below the orbit.

This species occurs in nearly every part of Australia, the extreme north and south excepted. It has been taken on the Murray and Darling, and specimens have come to liand from Brisbane, Port Curtis, and Rockhampton. All these snakes differ no more from those of Sydney than they do from each other. Much dependence cannot be placed on coloration as a distinguishing characteristic between snakes. No two of them vary so much from each other as does the same snake before and aftcr shedding its skin. The species under consideration is the most common in New 
South Wales. It frequents sandy localities, feeds on insects, small frogs, lizards, \&c, and its bite causes no more irritation than the sting of a bee. From 15 to 20 eggs are deposited by it once a year, under stones exposed to the sun generally in the beginning of December, or perhaps earlier, as on more than one occasion young snakes were taken at the end of that month and in the beginning of January. This reptile is generally found from two to thrce feet in length. During the cold season the Grey Snake retires beneath flat stones exposed to the sun; it very seldom, if ever, goes into the ground; it is very sensitive to cold, and the least frost will destroy it. Some times five and more of them have been found under the same stone during the cold season.

\section{Müller's SraKe. Diemenia müllleri.}

Elaps mülleri, Schleg. Ess., pl. 16, f. 16, 17 ; IFüll., Z. Ind. Arch., t. 9.

Pseudoelaps mülleri, Dum. \& Bibr., p. 1233.

This species, which is described as "olive, with two yellow or rosecolored streaks along the sides of head and neck," is probably a young or half-grown $D$. reticulata, which frequently exhibit rose-colored streaks on head and neck.

\section{Brown Srake. Diemenia superciliosa.}

(Plate VII, adult ; plate XI, figs. 10 and 10a, young.)

Pseudoelaps superciliosus, Fischer, Abhandlg. im Geb. der Natur. III, part 107, taf. 2, fig. 3.

Pseudoelaps sordellii, Jan, Rev. et IIag. Zool., pl. C.

Pseudoelaps kubinyi, Jan, i.e.

Diemenia anmulata, Gthr., Cat. of Colub. Snakes, p. 213.

Furina textilis, Krefft, Proc. Zool. Soc., 1862, p. 149.

Scales in 15 rows.

Two anal plates.

Abdominal plates, 228 .

Subcaudals, $73 / 73$, or more.

Total length, 5 to 6 feet.

Head, $1 \frac{1}{4}$ inch.

Tail, 10 inches.

Body elongate and rounded; head not very distinct from neck, high and quadrangular; superciliaries larger than the vertical; occipitals widely forked, rounded, broad; rostral high, reaching to the surface of crown; one nasal, one anterior, two posterior oculars ; superciliaries prominent above the eye; anterior ocular grooved near the top; posterior frontals 
much larger than the anterior ones, bent down on the sides, and with nasal, anterior ocular, and second and third upper labial replacing the loreal; belly flat. Dark brown above, a lighter band just crossing behind the occipitals ; side of face and chin much lighter than the other parts of the body; belly yellowish; sides of ventrals and lower edge clouded with purple grey, forming a series of irregular blotches; each ventral with a distinct darkish streak on its lower edge. Half-grown and sometimes adult individuals shew traces of from seventy to seventy-five black rings, which in the young snakes are very distinct. The following description is applicable to young specimens up to three years old :-Muzzle light brown; a black triangular spot covering the region between the eyes and the occiput, as far as the hinder margin of the occipitals-this streak is bent down on the sides of the face, and behind this dark spot is a white narrow streak and another broad dark band reaching down to the edge of the labial shields; then follows again a white streak and a second black band, but much smaller than the previous one, and so alternately a broader brownish and a narrow black band to within an inch of the apical half of the tail; the black bands are occasionally interrupted, leaving a blank on the other side of the body; including these interrupted streaks, from serenty to eighty may be counted upon body and tail-seventy-five is the usual number. The belly, in young and half-grown individuals, is covered with ycllowish spots, which, at a more mature age, form into the black blotches mentioned in the description of the adult. The young found on the Lachlan and in other localities to the westward of Sydney are not banded. Specimens from Adelaide are also without bands, colored with black patches upon head and neck. In a few years these bands and black spots disappear, more or less, and the adult snake is generally uniformly brown; there are some individuals on the coast, however, in which the bands may be traced when full grown. Specimens taken on the Murray had no bands or black marks. South Australian and other western examples are very dark when adult, sometimes almost black, and the abdominal plates covered with dark blotches much morc intense in color than in the N. S. Wales specimens.

The synonymy given above may be relied on. All the snakes of this species which Jan and others describe are referable to D. superciliosa; and a fine series of this snake, in all stages, from the egg upwards, will prove this to Museum visitors. 
The geographical range of this species extends over almost every part of Australia, and the collection embraces spccimens from Cape York, Adelaide, the Murray, and other localities. When full grown, this snake is dangerous to man; it is diurnal, and inhabits rocky localities; young individuals are frequently found under stones during the cold season, while those of a more mature age retire into the ground.

\section{Percy Island Snake. Diemenia torquata.}

(Plate XII, figs. 11 and 11a.)

Diemenia torquata. Gnthr., Ann., and IIag. of Nat. Hist., Ser. 3, vol. IX. p. 130.

Scales in 15 rows.

Abdominal plates, 206.

Two anal plates.

Subcaudals, $84 / 84$.

Total length, 22 inches 7 lines.

Head, 7 lines.

Tail, 6 inches.

The following description is given by Dr. Günther:-

Scales in fifteen rows, smooth. Brownish olive, each scale with a short white line at the basal portion of its outer margin; skin between the scales black; a brownish-black streak, edged with yellow, across the rostral shield and the loreal region, extending to the orbit. Posterior oculars yellow; a yellow streak edged with black from the eye to the angle of the mouth, continued into another similar band across the neck; another yellowish cross-band at some distance behind the former; the space between the two cross-bands dark brown, the whole forming a collar. Chin yellowish, marbled with grey; belly shining grey, a blackish band along the middle of the anterior half of the belly; tail reddish olive posteriorly.

Head flat; loreal replaced by the conjunction of four shields, as in the typical species; six upper labials, the third and fourth entering the orbit; two anterior temporals, the upper in contact with the lower postocular, the lower intercalated between the fifth and sixth labials. Scales without groove at the apex.

This snake is from Percy Island, which lies off the nortll-east coast of Australia, near Broad Sound. 
PSEUDONAJA, Günther.

Body and tail moderate; belly flat; head high, quadrangular, not very distinct from neck, with moderate rounded muzzle; rostral large, much produced backwards; anterior frontals smaller than posterior ones; vertical moderate; no loreal-replaced by the conjunction of posterior frontal, anterior ocular, second upper labial and posterior nasal; one anterior, two posterior oculars ; two nasals, nostril between; scales smooth, not much imbricate, in seventeen rows on the back; anal bifid; subcaudals two-rowed; anterior ribs not longer than following, rather more slender; grooved fang in front, a series of smaller equal teeth behind.

\section{North Australian Banded Snake. Pseudonaja muchalis.}

(Plate XII, fig. 13.)

Pseudonaja nuchalis, Günther, Cat. of Colubr. Snakes in Col. Brit. Mus., p. 227.

Scales in 17 rows; on neck, in 19 or 21 rows. Two anal plates.

Abdominals?

Subcaudals in two series.

Head (cleft of mouth), 1 inch.

Tail, 12 inches.

Total length, 64 inches.

Front side of the vertical shield shorter than the longest of the other edges; anterior frontals with a convex edge behind, and a rather obtuse angle in front; brownish olive, with very broad dark cross-bands, darkest on the neck; cross-bands sometimes obsolete, except that on the neck; body and tail modcrate, belly flat; head moderate, quadrangular, hardly distinct from neck, not depressed, with flat crown, and obtuse, rounded muzzle of moderate length; eye rather small; rostral shield much longer than broad, five-sided, so much produced backwards, as nearly to cover cntire front of muzzle, and extend between the anterior frontals, with a right angle bchind; anterior frontals rather small, with four sides, the hinder of which is convex; posterior frontals moderate, bent on the sides; vertical moderate, five-sided, with convergent outer edges, and a right 
angle behind; occipitals rounded behind, forked; superciliaries modcrate, prominent above the eye, two posterior oculars; one anterior (in one specimen two), deeply grooved before the cye, raised above the surface of the crown, but not reaching the vertical; two nasals (nostral between), anterior one largest, bent on the front of snout; six upper labials, third and fourth forming the lower edge of orbit, sixth largest, one larger, rhomboid, temporal shield in contact with lower postorbital, some others behind scale-like; six lower labials, and a very small scale-like shield behind; first pair lower labials very long, forming a long suture behind the medial one; the second small, narrow, and only one-fourth of the third; the fourth pair very large, in one specimen six-sided, in contact with the fifth, and with two chin-scales behind; scales rather elongate, rhomboidal, smooth, in seventeen rows, on the neck in nineteen or twentyone rows; anal bifid; all subcaudals two-rowed; upper jaw with one fang in front, separated from the following by an interval; an elongate series of five to six teeth behind, which are not grooved; palatine teeth equal; anterior teeth of lower jaw longest; brownish olive, or blackish olive; back of trunk, and tail, with ten to twelve very broad brown or black cross bands, the first on the neck being darkest; adult specimens exhibit the bands more or less obsolete, so as to become nearly uniform, the neck being always blackish brown, or ornamented with an angular brown spot; belly uniformly yellowish, in young individuals black-spotted. Length of cleft of mouth $1^{\prime \prime}$; length of tail $1^{\prime}$; total length $5^{\prime} 4^{\prime \prime}$.

The above is Dr. Günther's original description. The habitat of this snake is given as North-west Australia and Port Essington.

\section{PSEUDECHIS, Wagler.}

Body rather elongate and rounded; tail moderate, not distinct from trunk, tapering; head not distinct from neck, moderate, quadrangular, with moderate rounded muzzle; shields of crown moderate; two nasals, nostril between; no loreal; one anterior, two posterior oculars; scales smooth, imbricate, in seventeen rows; anal bifid ; first subcaudals entire, hinder ones two-rowed (exceptionally all entire). Grooved fang in front; some smaller, ones not grooved behind. 
Black Snake. Pseudechis porphyriacus.

(Plate VIII and plate XI, fig. 8.)

Coluber porphyriacus, Shaw, Zool. of N.H., p. 27, pl. 10; and Shaw, General Zool., III, p. 423 , pl. 110.

Pseudechis porphyriacus, Wagler, Syst. Amph., p. 171, and Günther, Cat. of Col. Snakes in Col. B. M., p. 218.

Naja porphyriaca, Schleg., Ess., pl. 17, figs. 10, 11.

Naja australis, Gray, Zool. Misc., p. 55.

Seales in 17 rows.

Two anal plates.

Abdominals, 180 to 200.

Subeaudals variable, from 50 to 60 , sometimes all divided or all entire, generally the first 10 to 20 entire, and the remainder divided.

Total length of adult, 5 to 6 feet.

Hlead, 1 inel.

Tail, 6 inehes.

Body elongate and rounded; tail moderate, not distinct from trunk; head rather small, quadrangular, with rounded muzzle; shields of crown regular; two nasals, no loreal; one anterior and two posterior oculars; seales smooth, imbrieate, in seventeen rows; anal bifid; first subcaudals entire, hinder ones two-rowed; in some individuals all the subcaudals are entire. Blaek above, eaeh seale of the outer series red at the base and blaek at the tip; ventral shields with black posterior margins; muzzle light brown.

The Blaek Snake is the most common of all our venomous snakes; it frequents low marshy plaees, is fond of water, dives and swims well, and subsists principally upon frogs, lizards, insects, and the smaller mammalia, in partieular the young of the Water-1at, Hydromys leucogaster. On one oeeasion sixteen young of this rodent were taken out of a specimen, so that the reptile must have plundered four nests.

When irritated, the Black Snake raises about two feet of its body off the ground, flattens out the neek like a Cobra, and then darts at its prey or cnemy. The bite of this snake is highly venomous, killing good-sized dogs or goats within an hour.

The number of young brought forth in Mareh generally amounts to 15 or 20 . During the winter the reptile retires into the ground. 
'There was a rumour at one time that the sexes were different in coloration, but this is not the case, as the large series of specimens in the collection of the Australian Museum sufficiently proves. It inlabits nearly every part of Australia, but is not found in Tasmania; the reptile known under the name of "Black Snake" in that island is a dark variety of the Hoplocephalus curtus or Brown-banded Snake, and identical with Hoplocephahus fuscus (Steindachner), lately described by that well-known Austrian naturalist as a ncw specics.

The present reptile grows to a considerable size, but seldom, if ever, exceeds six feet in length.

Orange-Bellied Brown SNaKe. Pseudechis australis.

(Plate VI, figs. 11 and 11a.)

Naja australis, Gray, Zool. Misc., p. 55.

Pseudechis australis, Günther, Ann. and Mag. of Nat. Hist., 3rd Series, vol. XII, p. 362.

Scales in 17 rows.

Two anal plates.

Abdominals, 199.

Subcaudals, $31_{28^{26}}^{26}$.

Head, $1 \frac{1}{2}$ inch.

Tail, 10 inches.

Total length, about 3 feet 6 inches.

This species is considered to be a variety of the Black Snake, and for such it has generally been taken by the few observers who have seen it in a state of nature. Dr. Gray's description of "light brown above and yellowish below" answers perfectly to preserved specimens, but when alive the colors differ more or less.

The back and sides are of a bright copper color, the outer row of scales having a rich orange spot in the centre of each scale; the abdominal plates are of deep yellow or orange, each plate having a darker margin, and its sides red or orange spotted. The general structure of the scales, shape of the head, and distribution of colors, is exactly as in the Black Snake. The nine principal head-shields cover a slightly larger space than those of the Psendechis porphyriacus, and the vertical shield has a different shape, the anterior margin being broader than the posterior one, which is the reverse in the Black Snake. Comparing the heads of both species, we find that of $P$. australis flatter and larger. 
The geographical distribution of this species appears to be restricted to the eastern districts; specimens were obtained in 1857 on the Murray River, and the single example in the Museum collection is a present from Wm. Macleay, Esq., F.L.S., who received it from Port Denison.

\section{BRACHYSOMA Günther.}

Body and tail moderate, rounded; head depressed, with flat crown and broad muzzle, obtuse in front; posterior frontal replacing the loreal, in contact with two labials; one anterior, two posterior oculars; one or two nasals. Scales smooth, short, large, in fifteen or seventeen rows; anal bifid; subcaudals two-rowed. Grooved fang in front; a series of smaller equal teeth behind.

\section{Scarlet-SPOTted Snake. Brachysoma diadema.}

(Plate XII, fig. 12.)

Calamaria diadema, Schleg. Ess., II, p. 35.

Elaps ornata, Gray, Zool. AIisc., p. 55.

Brachysoma diadema, Fitz., Syst. Rept., p. 25.

Furina diadema, Dum. \& Bibr., p. 1239.

Rabdion occipitale, Girard, U.S., Explor. Exp. Rept., p. 120.

Glyphodon ornatus, Gnthr., Colubr. Snakes, p. 210.

Brachysoma diadema, Gnthr., Ann. and IIag. Nat. Hist., vol. 11, 3rd series, p. 23.

Dr. Günther remarks :- “I have formerly confounded this snake with Furinu bimaculata, D. \& B. The genus which has been characterized by myself with the name of Glyphodon is valid, but must bear the name of Brachysoma; whilst for Brachysoma, Gnthr., the name of Furina, D. \& B., may be substituted." The following description is given by Dr. Günther :-

Scales in 15 rows.

Two anal plates.

Abdominals, 188 to 198.

Subcaudals, 46/46.

Length of cleft of mouth, $\frac{5}{12}$ inch.

Tail, $3 \frac{1}{4}$ inches.

Total length, 24 inches. 
Body and tail moderate, rounded, tapering bchind; head not very distinct from neck, depressed, with flat crown and broad muzzle, obtuse in front. Rostral shield broad, narrow, rounded behind, not much raised above surface of crown; anterior frontals broad, short; posterior ones much larger, bent down on the sides, replacing the loreal, in contact with second and third labials; vertical five-sided, with such obtuse lateral angles as ncarly to be three-sided, elongate, and with a very acute angle behind; occipitals moderate, rounded and forked behind; superciliary moderate; two posterior oculars; anterior ocular forming only the upper lialf of anterior edge of eye, the lower one being formed by the third labial; no loreal, one nasal, pierced by the nostril; seren upper labials, third and fourth coming into the orbit; one larger temporal shield in contact with both ocular's, five smaller ones behind, scale-like. Scales smooth, short, large, with rounded apcx, in fifteen rows; anal bifid; subcaudals two-rowed. Eye small, pupil elliptical, erect. Upper jaw with a grooved fang in front, separated from the other teeth by an interval; an elongate series of six to seven teeth behind; palatine teeth equal in length; anterior teeth of lower jaw longest. Above brown, each scale with a yellow spot in the centre; spots in younger individuals occupying nearly the whole scale, so as to give the appearance of the scales being yellow, brown-edged; crown of head and neck black, separated by a broad white collar, very conspicuous in younger individuals, gradually becoming obsolete; belly uniformly yellowish. The oviduct of one specimen contained eight mature eggs, but without embryo. Length of egg $\frac{7}{8}$; breadth of $\operatorname{egg} \frac{1}{3}{ }^{\prime \prime} . \quad$ (Günther.)

There is nothing to add to the present description, except that "the broad white collar" is bright scarlet in living specimens, and that the anterior part of the under lip is always black; the head is very distinct from the trunk; and the largest example which was ever obtained for the Museum collection is but 14 inches long. Our figure is considerably enlarged.

Specimens of this very handsome little snake lave been received from almost every part of Australia north of the Murray River. The Muscum examples are all from the east coast-the most northerm oncs fron Clercland Bay. 


\section{MacGiluIvray's Snake. Brachysoma triste.}

Glyphodon tristis, Gthr., Colubr. Snakes, p. 211.

Brachysoma triste, Gthr., Ann. \& Mag. Nat. Hist., 3rd Series, vol. XI, p. 24.

Scales in 17 rows.

Two anal plates.

Abdominals?

Subcaudals ?

Total length, $32^{\prime \prime}$.

Above uniformly blackish brown, scales of the sides obscurely lighter-edged; scales in seventeen rows; vertical broad, six-sided, with an obtuse angle in front, and a right one behind; outer edges much convergent; two nasals, nostril between ; first temporal shield not much larger than hinder ones, and in contact with both oculars; scales smooth, rhomboidal, in seventeen rows; anal bifid; above uniformly black; with a broad, brownish collar; scales on the sides lighter-edged; beneath uniformly dull yellowish; the dark coloration of the sides extending on to the outer edge of each rentral plate.

Length of cleft of mouth, $\frac{3}{4}{ }^{\prime \prime}$; length of tail, $4 \frac{1}{2}$; ; total length, $32^{\prime \prime}$.

\section{FURINA, Dum. \& Bibr.}

Body cylindric, rather elongate; tail rather distinct from trurk, short, tapering, ending in an obtuse, conical scale; head not distinct from neck, moderate, rather depressed, rounded; rostral shield very large, protruding, rounded, extending between the anterior frontals; frontals nearly equal in size; vertical very broad, reaching the anterior ocular; no loreal, replaced by the conjunction of nasal, posterior frontal, and ocular; one nasal, pierced by the small rostral; one anterior, two posterior oculars. Scales smooth, not much imbricated, in not very oblique rows, short, with rather rounded apex, in fifteen rows; anal bifid; subcaudals, tworowed. Grooved tooth in front, a series of smooth teeth behind.

\section{Spotred SNAKe. Furina calonotos.}

Furina calonotos, Dum. \& Bibr., p. 1241, pl. 75 bis.

Brachysoma calonotos, Gnthr., Colubr. Snakes, p. 229.

The description in the British Museum Catalogue is- "Pale brown above; back black, punctated with white; head and neck black, with a white cross band before the eyes and a white collar. Tasmania." 
Duméril and Bibron state that this species inhabits Tasmania, where M. Verreaux discovered it in 1844. Many naturalists are resident in that island, and collectors pay frequent visits to it, but all have failed to obtain another specimen during four and twenty years. Dr. Günther mentions that the British Muscum received this snake from Baranquilla, at the mouth of the River Magdalena, in New Granada; but when the American genus Brachyurophis was discovered in Australia, Gïnther concluded that his collcctor deccired him, by purchasing the specimens of Furina calonotos in England. So much is certain, however,-- that this species does not inhabit Tasmania, and is not found in Southern Victoria or New South Wales.

It will be as well to state here that the Furina textilis of D. \& B. (though differing in the number of ocular shields) is in all probability a young specimen of Diemenia superciliosa with the oculars accidentally divided. There is a specimen with three posterior oculars in the Museum Collection.

\section{Verreaux's SNake. Furina bimaculata.}

Furina binaculata, Dum. \& Bibr., p. 1240. Brachysoma bimaculatum, Gnthr., Colubr. Snakes, p. 229.

"Pale brown above, head and neck black above, with white muzzle and white collar." Discovered in $\mathbf{1 8 4 4}$ in Tasmania, by M. Verreaux, no other specimen lias since been found.

An example of this snake has been purchased by the British Museum, the rendor giving West Australia as its habitat, which is a more likely locality than Tasmania.

\section{BRACHYUROPHIS, Günther.}

Body rounded; head short, not distinct from neck; tail short; rostral shield large, with a sharp anterior edge, but not recurved; two pairs of frontals; one nasal, no loreal, it being replaced by the hinder portion of the nasal. Scales smooth, rhombic, without groove, in seventeen rows; anal bifid, subcaudals two-rowed. Eye small, with circular pupil; the anterior maxillary tooth longest, grooved. 


\section{Austrautax Shont-Tatled SNake. Brachyurophis australis.}

(Plate YI, figs. 3, 3a, 3b, 3c, 3d.)

Simotes australis, Krefft, Proc. Zool. Soc., 1864, p. 180.

Brachyurophis australis, Gthr., Ann. and Mag. Nat. Hist., 3rd Series, vol. XV, p. 97.

Scales in 17 rows.

Abdominal plates, 160 to 163.

Two anal plates.

Subcaudals, in two series, 18/18.

Total length, $11 \frac{1}{2}$ inches.

Head, 4 lines.

Tail, $1 \frac{1}{8}$ inch.

Body cylindrical, rounded; head short, conical, not distinct from neck ; tail short, ending in a blunt point. Rostral shield much produced, flat in front, pointed behind, reaching backwards to between the anterior frontals, and slightly grooved at its base. One nasal, one anterior, and two posterior oculars; two temporals (in one specimen a third smaller one behind). Eye small ; pupil subelliptical, erect; no loreal-replaced by the nasal and anterior ocular; six upper labials, the third and fourth coming into the orbit; occipitals short, not much rounded behind, and but slightly forked. The general color is red, very bright on the posterior part of the body and tail; all the scales are slightly margined-some, much darker than others, have a whitish (in spirits) spot in the middle, and form into a series of half rings, of which there are about fifty-six upon the body and tail. The head is covered by a black band across the occiput, leaving the snout free, commencing from below the eye, and marking the fourth and fifth upper labials, the vertical, and nearly the whole of the occipitals; this black band is divided from a second band corering the neck by a whitish space.

The first specimen of this snake was discovered on the Clarence River; since then another example has becn received from the Burdekin River in Queensland. The northern one is darker in colour, has six upper and lower labials and one nasal shield. The Clarence River specimen is somewhat injured, and there appear to be two nasal shields instead of one; the upper labials are five in number, and the lower six. 
HOPLOCFPHALUS, Cuvier.

Body and tail moderate, sometimes stout; head quadrangular, somctimes ratler depressed, and not distinct from neck; with flat crown, and moderate rounded muzzle. Rostral moderate, no loreal-replaced by the conjunction of postcrior frontal, of anterior ocular, and of second upper labial and nasal ; one anterior, and two posterior oculars ; one nasal, pierced by the nostril. Scales smooth, and not mucl imbricated, in fifteen to twenty-one rows. Anal and subcaudals entire. Grooved fang in front; a series of smaller equal teeth behind. (Viviparous.)

Brown-Banded SNake. Hoplocephalus curtus.

(Plate IX and plate XI, fig. 6.)

Naja curta, Schlegel, Ess. II, p. 486, and Abbild., t. 48, f. 19, 20. Günther, Cat. Colub. Snakes in Coll. Brit. Alus., p. 216.

Scales in 18 rows anteriorly, and in 19 rows posteriorly.

Abdominal plates, 170 or more.

One anal plate.

Subcaudals in a single scries, 40 to 50 .

Total length, from 5 to 6 feet.

Head, $1 \frac{1}{2}$ incl.

Tail, 7 inches.

Body moderately elongate; tail moderate, not distinct from trunk; head large and broad, crown flat, and muzzle rounded. The middle plate of the head (the rertical shield) is almost square-a distinguishing characteristic between this snake and the Hoplocephalus superbus.

The body scales are elongate, of equal size, and do not overlap each other much; there is a considerable picce of black skin between them, which shews very distinctly when stretched, or when the reptile, being angry, flattens its body. In this species the color varies considerably, from grey to almost black, with distinct or indistinct bands, and straw yellow or bright orange abdominal plates. In West Australian specimens the bands are rery dark and distinct, but like marking occurs in N. S. Wales species also. The younger the snakes, the clearer the bands are defined, and living subjects are g'enerally copper-colored.

The posterior abdominal plates and the subcaudals are darker and more clouded with grey or black than the anterior ones. Tasmanian specimens differ; they are either black, witl a ycllow, more or less spotted 
or clouded belly, or greyish above, and of a similar color below, with here and there a few black spots upon the back, indicating the position of the obliterated bands. When black and only half-grown, the Tasmanian snakcs shew the bands very distinctly. This species inhabits almost every part of Australia, from the south to the Gulf of Carpentaria; it is the most dangerous of all our reptiles, and a fair bite from it will kill animals the size of a goat in about an hour. Upon its own body, or that of another highly venomous species, the bite has no effect.

Thirty or more young are produced, every season, varying in color quite as much as old individuals do. They retire into the ground in winter, and make their appearance, according to the temperature, in August or the beginning of September-in southern districts much later. When attacked, and seeing no means of escape, this snake raises the fore part of the body off the ground, not unlike a Cobra, to which it is closely allied, and flattens the neck, though not to such an extent as the Indian Naja tripudians.

LARGE-SCALED SNake. Hoplocephalus superbus.

(Plate XI, fig. 9.)

Holocephalus superbus, Günther, Cat. of Colubr. Snakes in Coll. Brit. MIus., p. 217.

Scales in 15 rows.

Abdominal plates, 150 to 160 .

One anal plate.

Subcaudals in one series, 50 or more.

Total length of adult, 5 to 6 feet.

Head, 1 inch.

Tail, 6 to 7 inches.

Shields of the head smaller than in $H$. curtus, the middle or vertical plate about as long again as broad; head high, rather distinct from neck, somewhat pointed; body stout, with very large ventral plates, all clouded towards the tail, clear, and of a bright yellow on the anterior part of the body; general color, a dark copper brown, the two outer rows of scales on each side with a pink or red spot in the middle, those near the neck often

- somewhat lighter; close to the tail the spots are less bright, and sometimes obliterated. Western individuals occur with darker heads, and without the pinkish outer row of scales. It is probable that there are as many variations in this as in other prolific species, so that it is difficult to give a description that will be applicable to cvery individual snake. 
The scales of the body are always arranged in 15 rows, and are consequently larger than those of $H$. curlus, which has from 17 to 19 rows; no bands are formed, and though the neck is rather rounded, the reptile appears to have the power of dilating it at will.

A single individual from Port Lincoln shows a very dark crown, a much distended neck, with two darker streaks resembling the marks on the neck of the Indian Naja. In this variety the scales are also in $\mathbf{1 5}$ rows, but smaller and rather more triangular than in the Tasmanian species. The range of this snake has been considered to be limited to Tasmania, where it is known as the "Diamond Snake," but during the last few years specimens from other parts of Australia have come to hand. The reptile inhabits Tasmania, Victoria, South and West Australia, and probably the western counties of New South Wales, though it has not yet been found on the east coast. Its habits are probably similar to those of $H$. curtus, which is fond of the water, and frequents extensive swamps and reed beds, or the banks of rivers or creeks. Frogs, lizards, young water rats, \&c., appear to be the principal food of this snake. The female is said to produce a large number of young, whicl, in Tasmania, are brought forth about the end of December. The strength of its poison has not been tested with certainty, as the snake is confounded, in Victoria in particular, with the Tiger or Brown-banded Snake (H. curtus), which species is generally alluded to when experiments have been made. From the examination of its teeth, one would conclude that it is of a highly venomous nature. Young specimens, if not more than two years old, have a very distinct vertebral line, a scale wide from a little below the head to the end of the tail ; the head is also lighter in color than in adults.

\section{Flinders' Sxake. Hoplocephalus ater.}

(Plate XI, fig. 11.)

Hoplocephalus ater, Krefft, Pioc. Zool. Soc., June 26th, 1866.

Scales in 17 rows.

Abdominal plates, 162.

One anal plate.

Subcaudals, 47 .

Total length, about 30 inches.

Head, $\frac{3}{4}$ inch.

Tail, 5 inches. 
General color, black, chin-shields whitish on outer margin; beneath bluish black, clouded with a somewhat lighter tint on the posterior part.

Head scarcely distinct from trunk, high, quadrangular, and obtuse in front; anterior frontals as large again as the posterior ones, vertical fivesided, just as long as broad; occipitals very large, and widely forked; six upper labials, the fifth largest, and leaving but one narrow temporal shield above it; behind this there are two more temporals, of which the upper is the largest. The occipitals do not come into contact with more than three scales on cach side, whilst one scale is wedged in between the fork, making seven scales in all. There are seven lower labials, one nasal, one anterior, and two postoculars; the pupil is rounded.

Habitat, Flinders' Range, South Australia. Discovered by Mr. George Masters, who found but one specimen.

\section{Broad-HeAded STAKE. Hoplocephalus variegatus.}

(Plate VI, figs. 6, 6a, 6b.)

Alecto variegata, Dum. \& Bibr., p. 1254.

Najæ bungaroides, Sshleg., Ess. II, p. 577.

Najæ bungaroides, Boie., Isis, 1828, p. 1034.

Naja bungaroides, Schlegel, Ess. II, p. 477, and Abbild., t. 48, f. 17, 18.

Alecto bungaroides, Dum. \& Bibr., p. 1257.

Hoplocephalus bungaroides, Günther, Cat. Colubr. Snakes in Cat. Brit. MLus., p. 213.

Hoplocephalus variegatus, Günther, ibid., p. 214.

Scales in 21 rows.

Abdominal plates, 210 or more.

One anal plate.

Subcaudals in a single series, from 40 to 50 or more. Total length of adult, 3 feet.

Head, 1 inch.

Tail, 4 inclies.

Body and tail of moderate sizc; head flat, broad behind, and very distinct from the neck; two outer rows of scales of bright yellow, and a spot of the same color in the corner of each ventral plate. The yellow markings become indistinct towards the tail, and are sometimes quite obliterated, though onc of the outer rows shows the spots generally as far as where 
the tail eommences; a series of irregular loop-like bands a seale wide whieh differ considerably in shape in each reptile cover the baek. The belly is of a shining dark lead color, much resembling that of the black-lead used for polishing grates or stoves. Plates and seales of the head, and the side of the faee, yellow-spotted. In spirit, all the yellow marks turn white.

The Broad-headed Snalic is very local, and has never been found in any part of Australia except on the soutll-east eoast. All the speeimens in the MIusenm, and many hundreds distributed among kindred institutions, were obtained in the immediate neighlbourhood of Sydney.

During the summer months they are very scarce, perhaps on account of their noeturnal habits, bnt as thcy hibernate under flat stones in sunny localities, it is not difficult to eollect a good many during the cold season; they are, however, not so numerous as they were six or eight years ago, their haunts having been invaded by the builder and the gardener. Broad-headed Snakes frequent open scrubby eountry; and the roeky coast-line from the entrance of Port Jackson to Botany Bay is still mueh frequented by them. On the shores of Middle Harbour, and of the Lame Cove and Parramatta inlets, many speeimens oecur. Few persons have ever seen this speeies, as it is not often met with in the day-time.

The bite of this snake is not suffieiently strong to endanger the life of man or of the larger animals; and experiments with goats and other quadrupeds, such as dogs, ant-eaters (Echidna), \&c., have never proved fatal. The greater number observed seldom exceeded eighteen inches in lengthindividuals of thirty-six inehes are perhaps the largest ever obtained. If a person be bitten by one of them, the simple act of sueking the wound is sufficient to avert any unpleasant sensation; but should nothing be done, a violent headache, a eertain stiffness in the spine, and some local swelling, is generally the consequenee. It takes from thirty minutes to an hour before these symptoms set in.

The snake whieh $\mathrm{Mr}$. Schlegel describes as Naja bungaroides, in his Abbildungen, tab. 18; figs. 17 and 18, is one of the many varieties of the present species. 
Stephens' Banded Snake. Hoplocephalus stephensii.

(Plate VI, fig. 7.)

Hoplocephalus stephensii, spec. nov.

Scales in 21 rows.

Abdominal plates, 239.

One anal plate.

Subcaudals, 60 .

Head, $1 \frac{1}{8}$ inch.

Tail, $4 \frac{1}{2}$ inches.

Total length, 30 inches.

Body rather elongate, with flat quadrangular belly ; a kind of sharp fold, almost amounting to a keel (similar to that in the genus Dendrophis), runs from the neck to the vent on each side, defining the middle portion of the abdominal scales, and leaving a part the size of a scale on the sides of the body.

The head is not so broad and distinct from the trunk as in H. variegatus, but it is rather large, and has its scales similarly arranged; the occipitals are more elongatc, and the vertical broader, with a sharp angle behind, cutting-in between them even more than is shown in our figure.

Thirty-eight black bands, or rather half-bands, cover the back from the head to the vent, and seven or eight the tail, those of the hinder part of the body being occasionally interrupted and irregular. Thirty-seven dirty white bands, half the size of the black ones, divide them, and both reach down to the ventral fold or keel, giving color to that part of the ventrals accordingly (either black or white). The chin shields, and the first twenty or thirty ventrals are spotted with yellow, the abdominal scales then assume a light lead color, becoming darker towards the tail. The head is less dark than that of H. variegatus, not so much spotted, and the stripe or loop, a scale wide, reaching from the eye to the occiput on each side, is very regular.

The principal difference between the two snakes is the sharp edge on each side of the ventrals, ${ }^{*}$ the distinct and clearly defined bands upon the back, and the variation of color in the outer row of scales and the corners of

* The ventral plates are deeply cut out on each side. 
the ventrals, which in hundreds of specimens of $H$. variegatus are always yellow throughout. An indication of the abdominal edge or kecl may be traced in $H$. variegatus, but it is not so defined as that of the prescnt specics. The snake was named in honor of W. J. Stephens, Esq., M.A., Oxon, and its habitat is Port Macquarie, on the Hastings River; it occurs probably also on the Manning River.

\section{Pale-Headed Shake. Hoplocephalus pallidiceps.}

(Plate XI, fig. 1.)

Hoplocephalus pallidiceps, Grünther, Cat. of Colubr. Snakes in Coll. Brit. Ilus., p. 214.

Scales in 15 rows.

Abdominal plates, 227.

One anal plate.

Subcaudals in one series, $\mathbf{5 5}$ or more.

Total length of adult, 30 inches.

Head, 1 inch.

Tail, 4 inches.

Dr. Günther's original description is as follows:-Scales in fiftecn rows; second and third upper labial shields truncated above. Blackish olive; head lighter; scales of the outer rows with yellowish apex. Body rather elongate, rounded; tail rather short, not very distinct from trunk, tapcring; head somewhat similar to that of Glyphodon unicolor, rather depressed, with broad, flat crown, hardly distinct from neck; muzzle rather short, broad, rounded in front; eye small, pupil subclliptical; rostral moderate, reaching the surface of head; anterior frontals moderate, broader than long, rounded in front; posterior frontals rather large, fivesided, each with two linder edges, forming together a right angle; vertical six-sided, longer than broad, with parallel outer edges, an obtuse angle in front, and an acute one behind; occipitals moderate, sometimes rather elongate, sometimes obtuse and rounded behind; superciliary.moderate; two postcrior oculars, and one anterior, just reaching the surface of the crown. This specics differs somewhat from the other Hoplocephali, in the shields replacing the loreal; the second and third upper labials, being truncated above, do not participatc in replacing it. Nasal rathcr clongatc, sharply 
pointed behind, pierced by the nostril; six upper labials. Scales moderate, rhomboidal, in fifteen rows ; anal entire. Grooved longer tooth in front, a series of smaller ones behind. Above uniformly blackish olive, beneath uniformly yellowish; centre of each subcaudal with an obsolete dark spot; scales of the outer rows with yellowish apex; head uniform light brownish olive.

This species is viviparous. In the oviduct of the specimen whose measurements here are stated, two perfectly developed embryos were observed. Length of cleft of mouth, $\frac{7}{12}$; length of tail, $3^{\prime \prime}$; total length, 24 ".

H. pallidiceps is allied to $H$. variegatus and stephensii, and has a broad head and keeled ventrals; it is one of the smaller species, which seldom exceed thirty inches in length, and whose bite would not be dangerous to man. This snake is rather rare, and does not occur near Sydney. The Australian Museum contains specimens from the Lachlan, the Clarence, and the Richmond River, and from many parts of Queensland. The most northern specimens were obtained at Port Denison.

GoulD's SNaKe. Hoplocephalus gouldii.

(Plate XII, fig. 2.)

Elaps gouldii, Gray, in Capt. Grey's Australia, p. 444, p1. 5, fig. 1 ; Günther, Cat. of Colubr. Snakes in Col. B. MI., p. 215.

Scales in 15 rows.

Abdominal plates, 159.

One anal plate.

Subcaudals, 28.

Total length, 17 inches.

Head, $\frac{3}{4}$ incli.

Tail, 2 inches.

Pale yellowish; the scales of the back small, six-sided, with a dark anterior margin, giving the back a netted appearance. Top of the hear and nape black, with a yellow spot on the rostral scale on each side just before the eyes. Head small, the occipital plates large, elongate; the nasal plate triangular; one moderate anterior, and two subequal posterior ocular shields; six upper and lower labial shields, the fourth under the eyes; 
eyes small, pupil round. There is an indistinct small yellow spot behind the upper part of the eye; but this may be an accidental variety, as the spots on the two sides are not equally defined.

A single specimen in the Museum collection, probably from South Australia. Capt. (now Sir George) Grey discovered the species on the West Coast.

Pont Lincoln Snake. Hoplocephalus spectabilis.

(Plate XII, fig. 4.)

Hoplocephalus gouldii, var. Krefft, Proc. Zool. Soc., 26 June, 1866.

Scales in 15 rows.

Abdominal plates, 148 or more.

One anal plate.

Total length, 12 inches.

Head, $\frac{5}{8}$ inch.

Tail, $1 \frac{3}{4}$ inch.

This species has been considered to be a variety of Hoplocephalus gouldii; this is not so, however, as the following description will show :-

Head depressed, scarcely distinct from trunk; vertical five-sided, with acute angle behind; occipitals large, not much forked; anterior frontals triangular; posterior frontals quadrangular, somewhat larger than the former. Six upper and six lower labial scales, smooth, rather short, six-sided, lighter on the outer margin.

Greyish brown above, yellowish white below; the marks upon the head vary in different individuals ; rostral, nasal, and anterior part of first pair of frontals marked with black; remaining portion of anterior frontals and whole of posterior ones reddish, after which another black patch covers the vertical, superciliaries and part of the occipitals; pupil subelliptical, erect; a third black spot covers the nape of the neck, about four scales wide, but not reaching to the sides. In some of the specimens the second black patch is continuous, leaving only the tips of the occipitals and the scale between them reddish.

Habitat, Port Lincoln, South Australia. Discovered by $\mathrm{Mr}$. G. Masters. 
Crowned Snake. Hoplocephalus coronatus.

(Plate VI, fig. 3.)

Elaps coronatus, Sehleg. Ess. II, p. 454, and Abbild., t. 46, figs. 12, 13. Gray, in Capt. Grey's Australia, pl. 5, f. 2.

Alecto coronata, Dum. \& Bibr., p. 1255, pl. 76, 6, f. 2.

Hoplocephalus coronatus, Günther, Cat. of Cotub. Shakes in Col. Brit. Mrus.

Scales in 15 rows.

Abdominal plates, 138 or more.

One anal plate.

Subcaudal plates, 46 or more.

Total length, 18 inches.

Head, $\frac{7}{8}$ inch.

Tail, $3 \frac{1}{2}$ inches.

Body short and stout; head flat, distinct from neck; tail short, tapering, distinct from trunk; back olive-green, lighter on the sides; head bluish olive above, on each side (crossing the rostral shield) a black beneath a white-edged streak, both joined by a broad black collar at the back of the head; under part of upper and lower labials and chin-shields dotted with black; ventral plates reddish or salmon-colored (in spirits), more or less black-edged; subcaudals more indistinctly marked; scales hexagonal, skin between them black; eye moderate, pupil rounded.

This, like the preceding species, inhabits Western Australia, and is as common in the neighbourhood of King George's Sound as Diemenia reticulata is near Sydney. Like most Hoplocephali, it frequents the sunny side of stony hills, brings forth from ten to fifteen young annually, and is diurnal in its habits. Specimens hare been captured in the western part of South Australia, and its range is supposed to extend beyond the Swan River. This species is not found in New South Wales.

Tasmanian Snake. Hoplocephahts coronoides.

(Plate XII, figs. 1, la.)

Hoplocephalus coronoides. Günther, Cat. of Colub. Snakes in Coll. Brit. Mlus., p. 215.

Scales in 15 rows.

Abdominal plates, 150 or more. $^{\circ}$

One anal plate.

Subcaudals, 46 to 50 .

Total length, 15 inches,

Head, $\frac{1}{2}$ inch.

Tail, $2 \frac{1}{2}$ inches. 
Body elongate and rounded; head and tail not distinct from trunk; scales rather elongate, and not much imbricated; shields of the head regular, vertical nearly twice as long as broad, and not larger than the superciliaries; rostral very low, scarcely reaching to the top of the snout; posterior frontals much larger than the anterior ones; nostrils in the middle of a single nasal shicld; one pre and two post oculars; temporals $2+2$; uniform dark olive brown above, bluish powdered with black below; tail salmon-colored towards the tip; a dark-edged white streak from below the nostril through the labials to the side of the neck; eye of moderate size, with a bright brown spot above the pupil.

The present species is peculiar to Tasmania, and allied to Hoplocephalus Mastersii and H. signatus; it differs from H. Mastersii in not having a collar, and from $H$. signatus in having only one white streak on each side of the head, as also in its more elongate vertical, and the much smaller size.

Mas'ters' Sxake. Hoplocephalus mastersii.

(Plate XII, fig. 6.)

\author{
Hoplocephalus mastersii, Krefft, Proc. Zool. Soc., 26 June, 1866. \\ Scales in 15 rows. \\ Abdominal plates, 136. \\ One anal plate. \\ Subcaudal plates, 40 or more. \\ Total length, 14 inches. \\ Head, $\frac{1}{2}$ inch. \\ Tail, 2 inches.
}

Head triangular, distinct from trunk, and pointed in front; vertical three times as long as broad; all the scales of the head much elongate; six upper and seven lower labials, and one anterior and two postoculars, the anterior one grooved.

Dark olive-green above and below, with the exception of a yellowish-white elongate patch in the middle of each ventral scale; all the scales are very finely striated or keeled (which is not discernible with the 
naked eye), and more or less finely black-dotted. Head darker than the body, a whitish band crossing the nape; a second white band, spotted with black beneath the eye, from the rostral to the last upper labial.

In young specimens the ventral scales in the middle of body are red.

Habitat, Flinders' Range, South Australia. Collected by Mr. George Masters, who found seven specimens.

\section{Black-beluted Snake. Hoplocephatus signatus.}

Hoplocephalus signatus, Jan.

(Plate XII, fig. 5.)

Scales in 17 rows.

Abdominal plates, 157.

Two anal plates.

Subcaudals in a single series, 51 or more.

Total length of adult, 24 to 30 inches.

Head, $\frac{3}{4}$ inch.

Tail, 4 inches.

Body rather elongate and rounded, head and tail slightly distinct from trunk, head shields regular, the vertical differing considerably in shape in various specimens, six-sided, about as long again as broad, with sharp angles in front and behind; nostril reaching to the top of the snout, with a groove on the lower edge ; six upper (and lower) labials, the third and fourth coming into the orbit; eye moderate, pupil rounded, with a bright brown spot above it. First and second row of scales rather brown; skim between the scales black, above uniform dark olive green or brown, beneath deep bluish black; the head is generally lightcr in color, particularly towards the snout; a white streak from behind the eye to the side of the neck, another from the nasal to the last uppcr labial; lower lip, chin, and part of neck (below) whitish. The ventral plates vary much; the general color is bluish black, the outer edges sometimes dotted with grey; in one specimen received from Mr. William Bell, M.R.C.S., the ventrals are salmon-colored in the middle.

This species has a wide distribution ; it is mentioned from the neighbourhood of Melbourne, occurs frequently in thc southern districts of New South Wales, and has been taken in Queensland, near Ipswich, by $\mathrm{Mr}$. Masters. The femalc produces from fifteen to twenty young. The bite of this snake is not dangerous. 


\section{Temporal Desert Snake. Hoplocephalus iemporalis.}

(Plate VI, figs. 5, 5ณ.)

Hoplocephalus temporalis, Günther, Ann. and IIag. Nat. Hist., Series 3, vol. IX, p. 130 , pl. IX, fig. 11.

Scales in 19 rows.

Abdominal plates, 129 to 132.

One anal plate.

Subcaudal plates in a single series, 35 to 37 .

Total length, 20 inches.

Head, $\frac{3}{4}$ incll.

Tail, $2 \frac{3}{4}$ inches.

Scales in nineteen rows; six upper labials, the second of which is pointed above, the third truncated; temporal shields small, numerous, in three series; two temporals are in contact with the postorbitals, and a third below is intercalated between the two posterior labials.

Body stout, thick; tail rather short; head short and broad, distinct from neck; eye small, pupil subelliptical. Rostral shield triangular, nearly as high as broad, rounded above; anterior frontals small, broader than long, posterior frontals of moderate size, rounded posteriorly; vertical five-sided, much longer than broad, with parallel outer edges, and a pointed posterior angle; occipitals of moderate size; two posterior oculars, one anterior just reaching to the upper surface of the head. The postfrontal, nasal, ante-orbital and second upper labial, meet at a point and replace the loreal. Six upper labials; the first is lower than the following, the thind and fourth enter the orbit. The chief character by which the species may be readily distinguished is, the increased number of temporal shields, as stated above. Scales round the neck small. Chin-shields of nearly equal size; several scales between the hinder chin-shields and the first rentral; 129-132 ventrals, 1 anal, 35-37 subcaudals ; a series of four teeth behind the grooved front tooth. Uniform olive-brown or chestnut-brown above, uniform yellowish below.

The five specimens in the British Museum are from South Australia (locality unknown); the longest (adult female) is 20 inches, the head being $\frac{3}{4}$ inch and the tail $2 \frac{3}{4}$ inches long. It feeds on frogs. The Australian Museum is in possession of specimens from King George's Sound, collected by Mr. George Masters, who states that the largest snakes observed did not exceed 24 inches in length. The description given is by Dr. Günther. 
Rausay's SnaKe. Hoplocephalus ramsayi.

(Plate XI, fig. 2.)

Hoplocephalus ramsayi, Krefft, Proc. Zool. Soc., 1864, p. 181.

Scales in 15 rows.

Abdominal plates, 164 .

Two anal plates.

Subcaudal plates in a single series, 51 .

Total length, $10 \frac{1}{2}$ inches.

Tail, 2 inches.

Body rather elongate and rounded; head scarcely distinct from neck, rather high and elongate, with obtuse muzzle; rostral just reaching to the surface of crown; anterior frontals moderate, rounded in front; posterior ones lar'ger, bent down on the sides; one anterior, two posterior oculars, the lower forming about one-fourth of the orbit; vertical narrow, six-sided, much longer than broad; superciliaries nearly the same size as the vertical; occipitals moderate, not forked behind; six upper labials, the third and fourth forming the lower part of the orbit; no loreal, replaced by the elongate nasal, second and third upper labial, anterior ocular, and bent down anterior frontal; one nasal, pierced by the nostril; scales moderate, rhomboidal, in fifteen rows; tail rather short, scarcely distinct from trunk, tapering ; eye moderate, pupil rounded; grooved fang in front, some smaller smooth teetl behind.

Dark olive-green above, each scale tipped with reddish, in particular those on the sides; crown and a narrow vertebral line, one scale wide, somewhat darker than the other parts; this line extends to the root of the tail; upper labials and chin-shields whitish, marked with olive-brown in the upper corners. Beneath yellow, each ventral scale with a blackish margin; subcaudals nearly black.

Mr. E. P. Ramsay discovered this new snake in the neighbourhood of Braidwood, N. S. Wales; it is apparently a young specimen, its total length not exceeding $10 \frac{1}{2}$ inches. 


\section{Desert Snake. Hoplocephalus minor.}

(Plate VI, fig. 8.)

Hoplocephalus minor, Günther, Ann. and Magaz. of Nat. Hist., 3rd Series, vol. XII, p. 362.

Scales in 15 rows.

Abdominal plates, 125 to 128.

One anal plate.

Subcaudal plates, 54 to 59 .

Total length, from 18 to 24 inches.

The following is Dr. Günther's original description :-

Scales in fifteen rows; vertical shield not quite twice as long as broad; temporals $2+2+2$. Uniform olive-brown above, ycllowish below.

This species is similar to $\pi$. superbus, but it remains much smaller. The head is rather small, of moderate length and width, not depressed. The lower of the two anterior temporals is small, smaller than the last labial. The chin-shields of the postcrior pair are separated from each other by scalcs. Ventral shields, 125-128 (H. superbus, 148-153); subcaudals fifty-nine in the male, fifty-four in the female. All the lower parts arc yellowish, each ventral shicld having a blackish base.

An adult (pregnant) female is $17 \frac{1}{2}$ inches long, the tail measuring 4 inches. All other British Museum specimens are still smaller, although mature. This species inhabits S. W. Australia, whilst $H$. superbus proves to be a Tasmanian species.

With regard to the coloration of this snake, it will perhaps be better to describe one of the specimens in the Australian Museum collection, as they are probably better preserved than those in the British Museum. The vertical is about the same size and form as in a young H. super'bus, but the scales are more imbricated, the outer rows not so large, and the chin-shields much inorc elongatc. The head of an adult H. minor is much smaller than that of a young $H$. superbus of the same size, and there is a distinct half collar, just behind the head, which is vcry plain in young specimens; in old suljects this mark takes the form of two light spots behind the termination of the moutl. The ventrals are black-edged, and the marks much broader in the middlc. The Muscum specimens werc obtained by Mr. George Mastcrs, at King Gcorge's Sound. 
BLACK-NAPED SNaKe. Hoplocephalus nigriceps.

(Plate XI, fig. 7.)

Hoplocephalus nigriceps, Günther, Annal. and Magaz. of Nat. Hist., 3rd Series, vol. XII, p. 362.

Scales in 15 rows.

Abdominal plates, 154 .

One anal plate.

Subcaudals in a single series, 29.

Total length, 16 inches.

Head, $6 \frac{1}{2}$ lines.

Tail, 2 inches.

Dr. Günther's description is as follows :-

Scales in fifteen rows; upper parts of the head and nape of the neck uniformly black. Body of moderate length; head rather depressed; tail short; eye small, with vertical pupil; snout broad. Vertical shield five-sided, two-thirds as broad as long; two postoculars; six upper labials, the third and fourth of which enter the orbit; temporals $2+2+3$; only the upper of the two anterior temporals is in contact with the postoculars, the lower being intercalated between the fifth and sixth labials. The anterior pair of lower labials are large, as large as the front chin-shield. Ventrals, 154; subcaudals, 29. Uniformly brownish olive above, each scale being lighter at the tip. Upper parts of the head and nape uniformly black; lower parts whitish, immaculate.

There is a specimen of this snake in the Museum collection, that was obtained in the Western Districts of New South Wales. This proves the species to be Australian, as Dr. Güntlier first suspected ; it is allied to Moplocephalus gouldii.

BlaCk-BaCked SNake. Hoploceplalus nigrescens.

(Plate VI, figs. 4, 4a.) p. 131.

Hoplocephalus nigrescens, Günther, Ann. and Mlagaz. of Nat. Hist., vol. IX, 3rd Series,

Scales in 15 rows.

Abdominal plates, 170 to 200 .

One anal plate.

Subcaudals, 30 to 46 .

Total length, 32 inches.

Head, 1 inch.

Tail, $3 \frac{1}{2}$ inches. 
Scales in 15 rows, 6 upper labials, the second of which is pointed above, the third truncated. Uniform bluish grey or purple black above; ventral shiclds whitish, blackish on the sides. Body rather elongate, rounded; tail somewliat short, not distinct from trunk; head oblong, depressed, not distinct from neck; eye small, pupil sub-elliptical. Rostral shield very broad and low, and very obtuse superiorly; anterior frontals moderate, broader than long, rounded in front; posterior frontals rather large, five-sided, each with two linder edges, forming together a right angle ; vertical six-sided, about as broad as long, with parallel outer edges, and obtuse angle in front, and a pointed one behind; occipitals oblong, obtusely rounded behind; superciliaries small; two posterior oculars, one anterior just reaching to the upper surface of the head; the postfrontal, nasal, anteorbital, and sccond upper labial, meet at a point and replace the loreals; six upper labials; the first is very low, situated bclow the nasal, the third and fourth enter the orbit; front series of temporals formed by two shields, one of which is in contact with the postorbitals. Chin-shields of nearly equal size; sereral scales between the hinder chin-shields and the first ventral; the median line of the upper part of the tail is occupied by a series of hexagonal scales; a series of small teeth behind the grooved front tooth.

The present species is subject to a considerable variation of color during the course of the year; somctimes before changing its skin the back and head are of a leaden hue, and the ventral plates uniformly whitish; after the old skin has becn cast off, the upper coat assumes a shining deep purple or bluish-black; the ventral plates are at this time rose-colored, which tint is invariably lost in spirits. The rentrals of many subjects examined were found clouded on the sides; sometimes the greater part of the scales, in particular those near the rent, are blackish, and the subcaudals entirely so. It is probably the only snake of the genus Hoplocephalus in which the tongue is white.

The rocky neighbourhood of Middle Harbour (Port Jackson) is the locality where this new species was first discovered, but since then specimens have been obtained from Port Macquaric and the Clarence River, which do not differ in color from those inhabiting the neighbourhood of Sydney; it is highly probable that the geographical distribution of this species extends still further to the northward. Mr. George Masters obtained a very large specimen, thirty-two inches in length, at Wide Bay in Queensland. 
The present species is perhaps the nearest ally of the Ringed Snake (Vermicella occipitalis), and, like that serpent, it permits itself to be handled without attempting to bite; there is a peculiar polish on the closely adhercnt scales, just as in the Vermicella; the tail is very short, the eye diminutive, and the tongue white; the body scales are broad and rounded, and in all its characteristics this snake differs so much from other Hoplocephali that a separate genus will probably be formed for it.

BLACK-STRIPED SraKe. Hoplocephalus nigro-striatus.

$$
\text { (Plate XII, fig. 3.) }
$$

Hoplocephalus nigro-striatus. Krefft, Proc. Zool. Soc., 1864, p. 181.

Scales in 15 rows.

Abdominal plates, 150.

One anal plate.

Subcaudal plates in a single series, 62.

Total length, 11 inches.

Tail, $2 \frac{1}{2}$ inches.

Body and tail as in $H$. nigrescens; belly flat; tail moderate, not distinct from trunk; liead not distinct from neck, depressed, rounded; rostral moderate; anterior frontals broad, hinder edges just touching the nostril ; posterior frontals much larger, rounded behind; rertical moderate, six-sided, very broad; occipitals rather narrow, elongate, mucl forked and pointed behind; one anterior, two posterior oculars; superciliaries and eycs small; pupil elliptical, erect; six upper. labials, third and fourth touching the eye. Upper part of posterior half of tail covered with large hexagonal scales; sides and beneatl yellowish white; crown, and a vertebral line running from the neck to the tip of the tail, black.

A very fine specimen of this snake has been received from Cleveland Bay, by Captain Harley, of the steamer "Havilal." Mr. George Salting discovered the first specimen near Rockhampton. 
TROPIDECHIS, Günther.

Tropidechis, Günther, Ann. and MIagaz. of Nat. Hist., 3rd Series, vol. XII, p. 363.

This genus differs from Hoploceplaalus in having the scales keeled.

\section{Clarence River Snake. Tropidechis carinata.}

Hoplocephalus carinatus, Krefft, Proc. Zool. Soc., 1863, p. 86.

Scales in 23 rows.

Abdominal plates, 165 .

One anal plate.

Subcaudal plates, 54 .

Total length, 38 inches.

Head, $1 \frac{1}{4}$ inch.

Tail, 6 inches.

Body elongate and rounded; tail rather short, not distinct from the trunk, tapering, ending in a conical spine. Head broad, quadrangular, distinct from the neck; muzzle short and broad; eye moderate, pupil rounded; rostral broad, just reaching the surface of crown, with a groove along the lower edge; anterior frontals moderate; posterior frontals mucl larger, five-sided, rounded behind; vertical moderate, five-sided, with an acute angle behind ; superciliaries large, raised above the eye; occipitals moderate; one anterior ocular, slightly grooved; two posterior ones; one large temporal shield, two smaller ones behind; no loreal, this being replaced by the nasal ; the second upper labial, anterior ocular, and posterior frontal, bend down on the sides. Six upper labials, the third and fourth touching the orbit. Scales rather narrow and elongate, in twentythree rows anteriorly, somewhat broader, and in nineteen rows posteriorly, strongly keeled, forming fourteen raised lines upon the back and sides; brownish olive above, with some irregular interrupted blackish rings, which become more and more indistinct towards the tail ; skin between and upon the underside of the scales black; bclly whitish, clouded with purplish grey on the sides, much darker towards the tail, which is of a uniform purplish color below.

The present species was first discovered by Mr. James F. Wilcox, of South Grafton, on the Clarence River, a naturalist to whom the Museum is much indebted for many valuable additions to its stores. Mr. Wilcox captured two specimens only. Since then, another has come to hand from Port Nacquarie, on the Hastings River. 
The species is, no doubt, highly venomous, but not having received living examples no experiments could be made. In this as in other very dangerous snakes, a temporal shield is inserted betweeen the two last upper labials; this shield and a scale at the end of the line of mouth have been counted as labial shields in the original description, but they are not, and six labials above and below is the correct number.

\section{PFTRODYMON, Krefft.}

Petrodymon, Krefft, Transactions of the Philosophical Society of N. S. Wales for 1865.

Body rather elongate, rounded; head depressed, flat, not very distinct from neck; eye small, pupil elliptical; subcaudals in two series; tail short, distinct from trunk, ending in a conical spine or nail.

\section{Red-Bellied Snake. Petrodymon cucullatum.}

\section{(Plate VI, figs. 10 and 10a.)}

Diemansia cucullata, Günther, Ann. and Mrag. N. Hist., Ser. 3, vol. 9, p. 129.

Petrodymon cucullatum, Krefft, Transact. of the Phit. Soc. of N. S. Wales, for 1865.

Scales in 15 rows.

Abdominal plates, 187.

Two anal plates.

Subcaudal plates, 4:1/41.

Total length, 19 inches.

Head, $\frac{3}{4}$ inch.

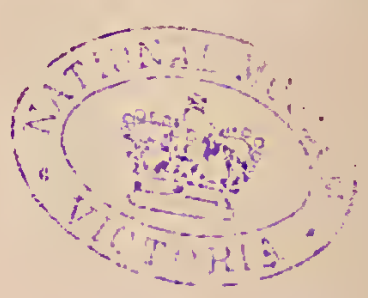

Tail, $2 \frac{1}{2}$ inches.

Purplish brown above, with a series of darker longitudinal lines along the upper part of the body, leaving a light elongate mark in the middle of each scale; beneath yellow, bright red in adult specimens, each ventral plate clouded on the upper edge with purplish brown much inter. rupted on the posterior part of the body. Divisional line of subcaudal plates marked in a similar manner, leaving the outer edges of the plates yellowish. Upper part of head purplish brown as far as the middle of posterior frontals, covering the vertical part of superciliaries, and reaching beyond the occipitals; this elliptical spot is joined to the back by a narrow band of the same color running along the median line of the neck. A light greyish band encircles the dark brown mark, divided by the narrow line 
which joins this mark to the back. Upper and lower labials dotted with brown spots. Body rounded; head rather flat, depressed; tail short, distinct from trunk, ending in a conical spine about a quarter of an inch long. Six upper labials, the third and forrth forming the lower edge of the orbit, the second labial not in contact with the posterior frontal; rostral broad, low, very obtuse superiorly ; shields of the head regular, all more or less rounded posteriorly, and slightly imbricated, vertical twice as long as broad*; one anterior and two posterior oculars, one temporal in contact with both oculars, four or five scale-like temporals behind; eve very small, pupil elliptical, and erect.

About nine years ago-in 1860 - a single individual of this species was captured; since then, owing to the exertions of correspondents in the country, specimens from Ash Island, on the Hunter River, Port Macquarie, the Clarence River, and other localities, have been received, so that its geographical range has been ascertained for many hundred miles along the east coast. This snake is strictly nocturnal in its habits, sluggish, and of gentle disposition, never offers to bite when handled, and though venomous, it is so in a very slight degree only, as has been proved by experiments ; its length seldom, if ever, exceeds thirty inches. Rocky and desolate places are frequented by it, and in such localities it is occasionally found under flat stones during the cold season.

Mr. G. Masters obtained this species last year at Wide Bay, in Queensland; but the finest specimens in the collection are those presented to the Museum by A. W. Scott, Esq., M.A.; they were captured at Ash Island, some of them have bright red abdominal plates, but the color has now faded in the spirit specimens.

CACOPHIS, Günther.

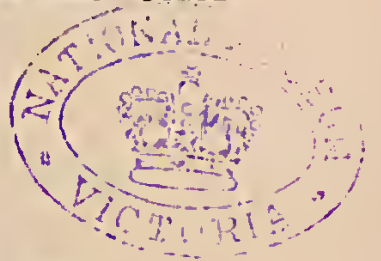

Cacophis, Günther, Annals and ILag. of Nat. Hist., 3rd Series, vol. XII, p. 361.

Body rather short, head small or of moderate size, not distinct from trunk; eye small, pupil elliptical ; tail moderate, rather thick, ending in a blunt spine; nostrils in a single nasal.

* This is not a constant character. 
Kreft's Dwarf SNaKe. Cacophis krefftii.

(Plate XI, figs. 5, 5a.)

Cacophis, krefftii, Günther, Annals and Alag. Nat. Hist., 3rd Series, vol. XII, p. 361.

Scales in 15 rows.

Abdominal plates, 156.

Two anal plates.

Subcaudals in two series, $28 / 28$ to $36 / 36$.

Total length, 12 inches.

Head, $\frac{3}{8}$ inch.

Tail, $1 \frac{1}{3}$ inch.

Scales smooth, in 15 rows; head rather depressed, of moderate width and length; rostral shield nearly twice as broad as high, scarcely reaching the upper surface of the head; anterior frontals not much smaller than posterior ; vertical rather longer than broad, six-sided, with an obtuse angle in front, and with a somewhat acute one behind; occipitals rounded behind, nearly as long as the vertical and posterior frontals together. Nasal elongate, simple, pierced by the nostril in the middle, in contact witl the single preocular (there is a small shield intercalated between the posterior frontal and the hind portion of the nasal). Two postoculars. Upper labials, 6 ; temporals, $1+2$. Three pairs of small chin-shields, subequal in size. Eye rather small, with the pupil round. Body rounded, of moderate length; tail rather short; ventrals, 156; anal bifid; subcaudals, 28.

Upper parts black, each scale of the outer series with an indistinct dark violet streak. A yellowish band commences on the snout, and passes through the eye and round the nape, where it is pure yellow, whilst its anterior and lateral portions are dotted with black; it is also longitudinally divided by a black line running from the eye for some distance backwards. Lower jaw brownish, marbled with yellowish. Each ventral shield yellow, with a black outer and hinder margin; a black band along the middle of the subcaudals.

Our figures are considerably enlarged. The lubitat of this species appears to be the N. E. Coast of Australia. Mr. James F. Wilcox sent the first specimens, and $M r$. George Masters obtained more examples north of the Clarence at Ipswich and Wide Bay in Queensland. No specimens are on record from the western portions of this continent. 
Forde's Dwarf Smake. Cacophis fordei.

(Plate XII, figs. 8, 8a.)

Cacophis fordei, Krefft, Proc. Zool. Soc., 1869.

Scales in 15 rows.

Abdominal plates, 167 to 172.

Subcaudals in two series, $36 / 36$.

Two anal plates.

Total length, 13 inches.

Head, $\frac{1}{2}$ inch.

Tail, $1_{4}^{\frac{3}{4}}$ inch.

Body elongate and rounded, head rather small, not distinct from trunk, flat, regularly shielded; vertical moderate, with a very sharp angle behind; superciliaries much smaller; occipitals slightly larger than the vertical; rostral rather depressed, with a groove on its lower edge; one anterior, two posterior oculars; one large and elongate temporal shield with two others behind, the upper one being nearly as large as the first temporal. Six upper labials, the third and fourth coming into the orbit; these shields increase from the first to the last, which is the largest. The lower labials are also six in number; the eye is small, with rounded pupil.

Scales hexagonal, about as broad as they are long, except the upper rows on the back, which are more elongate. The head is scarcely distinguishable from the body, and for one-fourth of the snake's whole length there is no increase in size; the body then gradually enlarges, being much stouter posteriorly, with a short and very distinct tail. In young and half-grown individuals, these characters are not so clearly defined, the tail is nearly of the same size as in the adult, rather stout, but distinct from the body. The general color is a kind of sepia brown above in adults, much lighter anteriorly, a white or yellowish collar dividing the head from the neck. This collar commences at the last labial shield, covers five scales in length, by one or (at the angle) two scales wide; it then crosses the neck, the width of a scale or less, and joins the opposite angle. The shields on the side of the face are all more or less spotted with white, including the outer edges of the superciliaries, the rostral, and the first pair of frontals. The general color of the body which covers the outer margins of every abdominal plate, is rather jagged and irregular in the middle, but sharply defined on the sides, particularly in young individuals; the imner margins of the tworowed subcaudals are marked in the same way to the tip. The abdominal 
plates are otherwise of a clear straw yellow, brighter in young subjects. The outer margin of each scale of the back is darkly shaded, with a light elongate spot in the middle, giving the body a keeled appearance.

Mr. George Masters discovered this handsome little snake at the Pine Mountain near Ipswich, Queensland, and he states that it could be freely handled without its offering to bite.

Our figures of it are much enlarged.

HarRTET'S SNake. Cacophis harrietta.

(Plate XI, fig. 13.)

Cacophis harriettx, Krefft, Proc. Zool. Soc., 1869.

Scales in 15 rows.

Abdominal plates, 193.

Two anal plates.

Subcaudals, 35-35, or more.

Total length, 12 inches.

Head, $\frac{1}{2}$ inch.

Tail, $1 \frac{1}{2}$ inch.

Body rather elongate and rounded; head scarcely distinct from trunk, quadrangular, not much depressed; tail rather short and stout, distinct from the body.

The vertical is rounded off behind, about as large again as the superciliaries; the occipitals are rather small and narrow, not much larger than the vertical (too large in our figure). The plates on the side of the face are similar to those of C.fordei; the third and fourth upper labials come under the eye, and the sixth and last is the largest; the temporal shields are, one large one, and two others of unequal size behind. The general color is a kind of purplish brown above, each scale with a white central streak (except the outcr row on each side), forming 13 thin lines from nape to base of tail ; head and neck white above, with a central spot (the color of the body) covering part of posterior frontals, vertical, superciliaries, occipitals, and one row of scales surrounding the occipitals. 
The shields on the side of the face, the lower labials, and chinshields, are dark spotted and blotched; eye small, pupil rounded. Abdominal plates uniform purplish brown, with a light outer edge; subcaudals with similar markings.

Habitat, Warro, Port Curtis, Queensland. Discovered by F. A. Blackman, Esq., of Warro.

Blackman's Snake. Cacophis blackmanii.

(Platé XII, fig. 9.)

Cacophis blackmanï, Krefft., Proc. Zool. Soc., 1869.

Scales in 15 lows.

Abdominal plates, 197.

Two anal plates.

Subcaudals, $43-43$, or more.

Total length, 16 inches.

Head, $\frac{5}{8}$ inch.

Tail, $2 \frac{1}{4}$ inches.

Body elongate and rounded, head distinct from neck, ratler depressed, with obtuse muzzle. The vertical, without the sharp angle behind, would form a square. The superciliaries are very small, slightly larger than the anterior ocular; occipitals also of small size, and not as large again as the vertical; the hind part of the head rather thick; the vertical and occipitals depressed.

Six upper labials, the two last of about equal size, with a large temporal shield wedged in between them; seven lower labials.

Purplish brown above, lighter on the sides; all scales with a slightly transparent outer margin, but without any markings; ventrals straw-yellow, with darker spots in the corners; head, from the muzzle to the occipitals, dark brown above; the upper margin of the upper labials tinted with the same color; the rest and the lower labials yellowish; mental shield dark brown. The upper part of the head behind the occipitals light brown; a clear small spot in the corner of each superciliary plate yellow.

Habitat, the Pine Mountain, Queensland. Discovered by Mr. George Master's. 


\title{
VFRMICFILA, Gray.
}

Body elongate, rounded; tail very short; head similar to Elaps; one nasal, pierced by the nostril; no loreal—replaced by anterior ocular and nasal; one anterior, two posterior oculars. Scales smooth, not much imbricated, in fifteen rows; those of the vertebral line not larger; anal and subcaudals bifid. Grooved minute fang in front; no other tooth behind.

This genus shews the remarkable fact, that the Australian Conocerci, without smooth teeth behind the fang, are more closely allied to the American Elaps than to the East Indian ones. (Giinther.)

\section{Black and white Ringed SNake. Vermicella anmulata.}

\section{(Plate XI, figs. 12 and 12a.)}

Vermicella annulata, Gray, ILSS. Brit. ILus., \& Günther, Cat. of Colubr. Snakes in Coll. Brit. Alus., p. 236.

\author{
Scales in 15 rows. \\ Abdominal plates, 225. \\ Two anal plates. \\ Subcaudals, 18/18. \\ Total length, 28 inches. \\ Head, $\frac{1}{2}$ inch. \\ Tail, $1 \frac{1}{2}$ inch.
}

The following is Dr. Günther's description:- "Body elongate, rounded, slightly compressed bchind; tail very short; lead moderate, not distinct from neck; rostral shield very large, rounded, raised above the surface of snout; occipitals rather narrow; two posterior oculars; anterior large, replacing the loreal together with the nasal; nasal shield single, pierced in the centre by the small nostril; six upper labials, third and fourth coming into the orbit; one large temporal shield in contact with the upper posterior ocular, two smaller ones behind. Scales smooth, large, rather rounded behind, in fifteen rows. Anal and subcaudals bifid. Tail ending in an obtuse conical scale. Two small fangs in front of upper jaw, no other teeth behind; palatine and mandibulary teeth equal in length. Crown of head and muzzle black; a yellowish (in fresh specimens white) band across the posterior frontals, a second on the neck; body and tail encircled by alternate black and white rings. Length of cleft of mouth, $\frac{11}{2}$; length of tail, $1 \frac{1}{2}{ }^{\prime \prime}$; total, $28^{\prime \prime} . "$ 
The geographical range of this species is very extensive; it inlabits almost every part of Australia, except the southern districts. The markings vary considerably in different individuals, but in all, complete rings are formed, the black bands being generally as large again as the white ones. Examples occur in which the black marks narrow very much on the belly, and others which have the head-shields rather irregular ; still it is difficult to find sufficient corresponding characters to warrant the establishment of a separate species. Since writing this, a very young Vermicella has been received from the Upper Burdekin, collected by Mr. Rainbird, for which we propose the specific name of lumulata, provided that older specimens, when discovered, will present the same markings. Our figures are somewhat enlarged.

Hatf-RtNGged SNake. Vermicella lumulata.

(Plate XII, figs. 14, 14a.)

Scales in 15 rows.

Abdominal plates, 220 or more.

Two anal plates.

Subcaudals, $26 / 26$ or more.

Total length, $8 \frac{1}{2}$ inches.

Head, less than $\frac{1}{4}$ inch.

Tail, $\frac{1}{2}$ inch.

Head very flat; rostral not quite so high as in $V$. annulata, vertical and occipitals more elongate ; head, body, and tail, covered by 59 elliptical spots, which, only in a few instances near the tail, join beneath, but very faint, and scarcely a line in width. On the middle of the back these spots are about $\frac{1}{8}$ inch wide.

Habitat, the Upper Burdekin. A single specimen in the Museum collection.

\section{AOANTHOPHIS, Daudin.}

Head depressed, shielded, prominent over the eyes; nostrils between two shields ; pupil erect, elliptical ; tail ending in a rccurved spine ; subcaudal plates one-rowed. Loreal shield absent; eyes surrounded beneath with a series of shields; labial shields large; middle rows of scales keeled. 
Death Adder. Acanthoplis antarctica.

(Plate $\mathrm{X}$ and plate XI, fig. 7.)

Acanthophis antarctica, Wagler, Syst., 172, Gray, Zool., MIisc., and Cat. of Specimens of Snakes in Coll. Brit. Muss., p. 34.

Scales in 21 rows.

Abdominal plates, 130 or more.

One anal plate.

Subcaudals, $18_{20}^{20}$ or more.

Total length, 32 inches.

Head, $2 \frac{1}{4}$ inches long, $1 \frac{5}{8}$ inch broad.

Tail, 4 inches.

Girth round body, 9 inches. collection.

The measurements are from the largest specimen in the Museum

Body short, stout, and rounded, covered with scales of various shapes, those near the neck being lanceolate, and the upper nine or ten rows strongly keeled. About the middle of the body the keels disippear, or become very faint; in specimens not more than a year old, the keels can scarcely be traced. On the posterior half of the body the scales are larger, rounded, and very thin. The head is broad, prominent above the eyes, and one-third of the occiput covered with regular shields, which are, however, very rugged and indented, and, like the common body scales, much imbricated. There is one anterior and two posterior oculars, and two or three smaller scales between the eye and the third and fourth upper labial; the whole labial series above numbers six plates, the last two being the largest, with a very large temporal shield between them; the lower labials are seven, sometimes eight. The eye is very small, the pupil elliptical and erect, the scale above it is very prominent, and the anterior ocular has a strong groove on its lower edge. The vertical and the superciliaries are about equal in size, the occipitals short and broad, with rugged irregular outer edges; nearly all the ordinary scales of the hcad are keeled. The Death Adder differs from the true Vipers in having permanently erect fangs, which are perforated, not grooved, and, in this respect, the reptile resembles the Viperine Snakes. The short tail is much compressed near the tip, and the last nine or ten series of scales surrounding it become, in old subjects, very rigid and hard; the last scale of all is generally curved, and resembles a poison fang, but in old age only this spine hardens; young and halfgrown specimens lave it more or less soft and pliable. This spine, which is so much dreaded by many persons, is neither a weapon of attack or defence. 
The larger number of Death Adders are of a uniform grey color above, with forty or more darker rings from the neck to the tip of the tail; in very aged specimens these rings disappear or become very indistinct. There are many other varieties, some very pale grey or red, and some quite brick red, always more or less spotted or mottled with a darker color. The lower labial and chin shields are black-spotted in the ccntre, as also are frequently the scales of the first or outer row on cach side; pink spots also occur on these scales occasionally-in fact, all the grey Death Adders show them distinctly; but in spirits these pink spots disappear. The ventral plates, in all varieties, are clouded with black; the subcaudals show the same color, and the tip of the tail is yellow or orange.

The habitat of this species extends orer the whole of Australia, except Tasmania, South Victoria, and perhaps. South and South-west Australia. Dr. Gray records specimens from Port Essington, and from N.W. Australia. Our own specimens were collected in almost every district in New South Wales, and in parts of Queensland, extending as far even as Cape York.

That enterprising naturalist, Mr. Wallace, observed Death Adders on some of the Islands of the Arafura Sea.

From ten to fifteen young are produced annually, which, as soon as they have broken the covering, and are scarcely dry, begin to snap right and left when touched. There is one comfort, however, in the undoubted fact that this snake is not so venomous as has been represented. A few days ago experiments were made with a Lizard (Cyclodus gigas), a young specimen about 7 inches long, and though a large Acanthophis was applied to its body, the Lizard lived for twelve hours afterwards. A Green or Golden Tree Frog (Hyla aurea) bitten by the same snake, survived about as long. Former experiments have been made with similar results.*

* 'The popular name of "Adder" is applied to snakes and lizards; the Slecping Lizard is known as an "Adder," and eonsidered highly venomous by many persons. Not long ago, the death of a boy from the bite of an "Adder," was reeorded in the daily papers; it was stated that the brave little fellow tried to rescue his two dogs, both of which were bitten and died, and that the "Adder" jumped at him and wounded him in the leg; the Death Adder being rather sluggish in its habits, it is more than probable that the attacking reptile was a Brown-banded snake, Hoplocephalus curtus. 
The liabits of this species are tolerably well known; it frequents sandy localities, fecds on frogs, lizards, small mammals, \&c., and retires under ground from April or May to September. When disturbed it flattens out its whole body, and darts right and left as quick as thought, but it does not jump, and certainly never jumps backwards; it raises its head in the act of striking, and then slightly only; this must be mentioned, as our figure was taken from a preserved specimen. The head, plate XI, fig. 7, is that of the red variety.

DENISONIA, Kreff.

Head high and quadrangular, distinct from trunk, regularly shielded, but with a large loreal which is absent in all other Australian venomous snakes. Body not very elongate and rounded, tail distinct, cnding in a large conical spine. Scales in 17 rows; subcaudals entire.

\section{Ornamented Snake. Denisonia ornata.}

(Plate XI, fig. 4.)

Scales in 17 rows.

Abdominal plates, 136.

One anal plate.

Subcaudals, 29.

Total length, 6 inches.

Head, $\frac{1}{2}$ inch.

Tail, $\frac{3}{4}$ incll.

This species is a very peculiar form, on account of the loreal shield, which, in our venomous Colubrine Snakes is always absent. The head is rather thick, distinct from trunk, high, and quadrangular, with shelving snout, and, in this respect, resembling the genus Acanthophis. The markings of the upper and lower labials, the chin-shields, and the first 10 or 15 abdominal plates, are almost idcntical with those of young Death Adders of the first ycar. The occiput is black from the posterial frontals to the commencement of the neck, lcaving a mottled spot on the inner margin of the superciliarics, and another very small one at the posterior part of the vertical. The tips of the two occipitals and the scale between 
them are also light colored, and below these is another whitish spot, formed by the inner portions of eight scales with a darker centre. The occipitals are slightly raised above the eye, and rescmble, in this respect, the scales in the genus Acanthophis. The frontals shelve downwards, and the rostral is so low, as not to be visible from above if the head be put in a horizontal position. Body and tail above lead colored, beneath whitish; the abdominals liave brown spots in the corner of each plate, which become faint towards the tail.

Mr. Thomas Nobbs, a liberal donor to the Museum, discovered this new snake near Rockhampton, in Queensland.

\section{FAMILY OF SEA SNAKES-HYDROPHIDAE.*}

Body subcylindrical anteriorly, more or less compressed posteriorly ; tail strongly compressed, elevated, paddlc-shaped. Head shields generally abnormal ; loreal, none. Nostrils situated on the upper side of the head, except in Platurus. Eye small, with round pupil. The venom fang small, grooved in front, and with a canal in its interior terminating in a short slit.

"The Sea Snakes are inhabitants of the tropical parts of the Indian and Pacific Oceans, extending from the coast of Madagascar to the Isthmus of Panama; they are most numcrous in the East Indian Archipelago, and in the seas between Southern China and North Australia, being represented on the outskirts of the geographical range we have mentioned by only one species, and that the most common, viz., Pelamis bicolor. They pass their whole life in the water (with the exception perhaps of the Platurus), and soon die when brought on shore.

"The most striking fcature in the organization of the Sea Snakes is their elevated and compressed tail, the processes of the caudal vertebræ being much prolonged and styliform. The hind part of the body, and sometimes forwards to beyond the middle of its length, is also compressed, and the belly forms a more or less sharp ridge. The ventral shields would

\footnotetext{
* The remarks on the Sea Snakes are by Dr. A. Günther, F.R.S., originally published in the Reptiles of British India.
} 
be of no use to snakes moving through a fluid, and not over a rough hard surface, and therefore they are either only rudimentary or entirely absent. The genus Platurus, however, is a most remarkable exception, in having ordinary ventral shields; and this circumstance, together with the lateral position of its nostrils, induce me to believe that these serpents frequently go on shore, sporting or hunting over marshy ground. In many Sea Snakes the hind part of the body is curred and prehensile, so that they are enabled to secure a hold by twisting this part of the body round corals, seaweeds, or any other projecting object. Their tail answers all the purposes of the same organ in a fish, and their motions in the water are almost as rapid as they are uncertain and awkward when removed out of their proper element. Their nostrils are placed quite at the top of the snout, as in Crocodiles and in Fresh Water Snakes, so that they are enabled to breathe whilst the entire body and the greater part of the head are immersed in water. These openings are small and subcrescentic, and provided with a valve interiorly, which is opened during respiration, and closed when the animal dives. They have very capacious lungs, extending backwards to the anus, and consequently all their ribs are employed in performing the respiratory function; by retaining a portion of the air in these extensive lungs, they are enabled to float on the surface of the water witlout the slightest effort.

"The 'scales' of the Sea Snakes are frequently very different from those of other snakes; they overlap one another in only a few species (Platurus, Hydrophis stokesii, and belcheri); in others they are but little imbricate and rounded behind, and, again, in others they are of a subquadrangular or liexagonal form, placed side by side, like little shields; the less imbricate they are, the more they have lost the polished surface which we find in other snakes, and are soft, tubercular, sometimes porous. 'The form and the arrangement of the scales afford good specific characters, but it is necessary to observe that they generally differ in size, arrangement, and form, in the different parts of the body. In my descriptions I have always comnted the series of scales on the neck-that is, at a distance from the head abont equal to its length, having found that the numbers at that place are least subject to variation in diffcrent individuals; whilst I have taken the characters of the form or arrangement of the scales from those in or behind the middle of the body, the scales on the reck being narrow and more or less imbricated in almost all the species. 
"The shields of the head differ so much in their arrangement from those of other snakes, that a snake may be recognized as a marine species by an inspection of the head only. The large nasal shields occupy the upper anterior part of the snout, and are generally contiguous, replacing the anterior frontals, which are absent; the single pair of small frontals are homologous with the posterior frontals of other snakes. There is a vertical, a pair of superciliaries, and another of occipitals, one ocular, and one or two postocular's; the number of the latter is rather constant in the same species. Loreal, none. The labials are somewhat irregularly arranged, frequently subdivided, especially the posterior; in most of the species, small pieces, nearest to the labial margin, are detached from the lower labials. There is a triangular mental shield in front of the lower jaw, bchind which the first pair of lower labials form a suture together' one or two pairs of chin-shields follow. Sereral Sea Snakes are distinguished by having some or all of the head-shields broken up into smaller irregular pieces, whilst Platurus differs from all others in an arrangement of the shields which is extremely similar to that in the Elapide. The Sea Snakes shed their skin vcry frequently, and the skin peels off in pieces as in the Lizards, and not as in the Fresh-water Serpents, in which the integuments come off entire.

"Several species are remarkable for the extremely slender and prolonged anterior part of the body, for which we use the term 'neck,' and which terminates in a very small head. These snakes can hardly form a scparate genus, as we find a most complete transition from then to the forms with thick and short body. The extreme forms must differ considerably in their habits, but no observations on this point are on record.

"The eye is small, with round pupil, which is so much contracted by the light when the snake is taken out of the water, that the animal becomes blinded, and is unable to hit any object it wants to strike. The tongue is short, and the sheath in which it lies concealed opens near to the front margin of the lower jaw; scarcely more than the two terminating points are exserted from the mouth when the animal is in the water. The mouth shuts in a somewhat different way from that in other snakes, the middle of the rostral shield being prodnced downwards into a small lobule, which prevents the water from entering the mouth; this lobe is most 
devcloped in Enhydrina. There is generally a small notch on each side of the lobule, for the passage of the two points of the tongue. Cantor says that wlicn the snake is out of the water and blinded by the light, it freely makes use of its tongue as a feeler.

"The food of tlie Sea Snakes consists entirely of small fish; I have found all kinds of fish in their stomach-among them species with very strong spines (Apogon, Siluroids). As all these animals are killed by the poison of the snake before they are swallowed, and as their muscles are perfectly relaxed, their armature is harmless to the snake, which commences to swallow its prey from the head, and depresses the spine as deglutition proceeds.

"There cannot be the slightest doubt that the Sea Snakes belong to the most poisonous species of the whole order. Russell and Cantor hare ascertained it by direct observation ; tortoises, other snakes, and fish, died from their bite in less than an hour, and a man succumbed after four hours. Accidents are rarely caused by them, because they are extremely shy, and swim away on the least alarm; but when surprised in the submarine cavities forming their natural retreats, they will, like any other poisonous tcrestrial snake, dart at a pole ; or, when out of the water, they attempt to bite every object ncar them, even turning round to wound their own bodies. (Cantor.) They cannot endure captivity, dying in the course of two or thrce days, even when kept in capacious tanks.

"The males may be easily distinguished from the females by a distinct swelling on each side of the tail extending from the root to, or beyond, the middle of its length; sometimes the whole tail is thickened, and such specimens may be taken for distinct species. All the species are viviparous, bringing forth, without leaving the sea, from four to nine young ones. The young are more brightly colored than the adult, the faint cross bands of the latter being complete black rings in the former; the tail also of the young is comparatircly thicker, and less compressed than in the adult. That they live to a grcat age I infer from the circumstance that we find relatively very large examples of almost every species, but that such examples are very scarce. Now as they have very formidable and very numerous enemies in the sea cagles (Haliaëlus), in the sharks, and other raptatorial fishes, it appears to me to be a just conclusion that, if 
Sea Snakes of large dimensions were more numerous than they are, they would, in spite of their enemies, arrive at that size in a shorter period than that which we assume as necessary for their growth. The greatest size, however, to which some species attain, according to positive observation, is about twelve feet, and therefore, far short of the statements as to the length of the so-called 'Sea Serpents.' The largest example I have seen measured only eight feet.

" There is no other group of reptiles the species of which are so little known, and the synonymy of which is so confused, as that of the Sea Serpents. All the preceding authors, with the exception of Gray, have worked at them with the idea that the species were less numerous than they in reality are; thus confounding forms which had been previously distinguished, though imperfectly characterized. Having had the great advantage of examining and comparing, first a portion of Russell's typical specimens captured in the same seas as those from which Russell received his examples, and secondly, the types of Shaw and Gray, I find the results of my examinations so much at variance with those of others, that it is necessary to treat on all the species of this family, and not to confine myself to those alone which are supposed to be found in the Indian Seas, Moreover, our present knowledge of the geographical distribution of most of the species is extremely vague, and I have reason to believe that, as in other families of snakes, so in the Sea Snakes numerous species are very local, whilst others extend over an enormous area." (Giunther.)

The above lucid remarks on the Sea Snakes, and Dr. Günther's subsequent descriptions of the known genera and species, have enabled the author to classify all the Museum specimens, and to distinguish two new species, which differ so much from all other forms that it was considered necessary to establish a new genus for them. These species are allied to Aipysurus, and will be arranged between that genus and Disteira. All the known genera are therefore enumerated in the catalogue, though only those species have been selected from Dr. Günther's Work which are supposed to inlabit the Australian seas. 


\section{Synopsis of the Genera.}

A. Ventral shields well developed, flat.

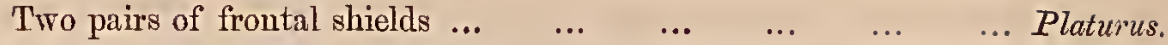

B. Tentral shields well developed, with a median ridge.

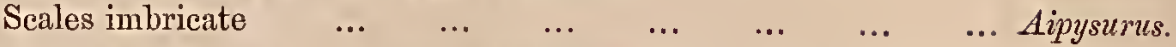

C. Ventral shields lasge, with a very slight median ridge.

Labial shields reduced to three above and below; scales imbricate,

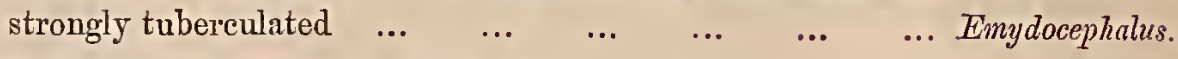

D. Ventral shields narrow, or rudimentary, or absent.

* Nasals separated by frontal shields.

Ventral shields distinct to the vent ... $\quad \ldots \quad \ldots \quad \ldots \quad \ldots \quad \ldots$ Disteir $\alpha$.

**Nasals contiguous.

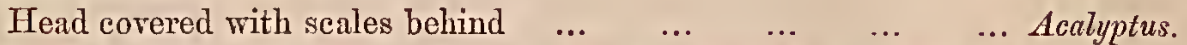

Head short or of moderate length, entirely shielded; lower jaw without noteh in front $\begin{array}{lllllll}. . & \ldots & \ldots & \ldots & \ldots & \ldots & \text { Hydrophis. }\end{array}$

Head of moderate length, entirely shielded; lower jaw deeply

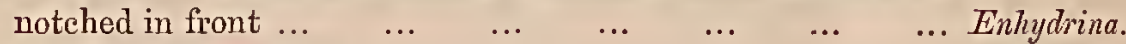

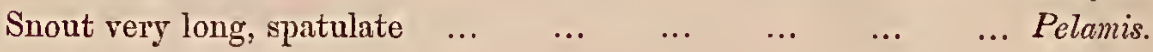

\section{PIATURUS, Latr.}

Body subeylindrical, of moderate length. Shields of the head subnormal in number and arrangement; nostrils lateral, in a single nasal shicld, both nasals being separated from each other by a pair of anterior frontals. Seales imbrieate, smooth; ventral shields well developed. tail with two series of subeaudals.

This genus approaches the Land Snakes in several eharaeters. The shields of the head are very regularly disposed; there are two pairs of frontals, frequently with an azygos shield between the hind pair. The nostril is lateral, piereing a narrow nasal shield; loreal absent. One pre and two post oculars. Seven upper labials, the third and fourth of whieh enter the orbit; temporals seale-like $1+2+3$. The throat is eovered by two pairs of ehin-shields anteriorly and by seales posteriorly, the rentrals eommeneing at some distanee behind the liead. The seales are regularly imbrieate, smooth, sliort, slightly rounded behind; the number of longitudinal series on the body varies mueh, from nineteen to twenty-five, in different individuals, without affording a character for specifie distinetion; it is more constant on the front part of the trunk. The rentral shields 
are broad, and somctimes show a lateral keel. Anal bifid. The tail is longer and thicker in males than in females, and covercd with high short shield-like scales, the two lower series of which may be considered as subcaudals.

The poison-fang is short, and not followed by a series of other simple teeth, as in Fydrophis. A vcry small single tooth is implanted at some distance behind the poison-fang, and is frequently lost.

These snakes have quite the pliysiognomy of an Elaps, and the cleft of the mouth is not turned upwards behind, as in other Sea Snakes; the eye is rather small. Neither the tail or the hind part of the body is prehensile; and although we have not received positive information concerning their habits, it becomes evident from their whole organization that they must differ considerably from the other types of the family in this respect. (Gïnther.)

This is one of the two genera of Sca Snakes which occur occasionally on the coast of New South Wales.

\section{Ringed Sea Srake. Platurus scutatus.}

Platurus scutatus, Gïnther, Reptiles of Brit. India, p. 356.

Generally an azygos shield between the posterior frontals; scales of the front part of the trunk in twenty-one or twenty-three longitudinal series; rentral shields from 213 to 241 . Body surrounded by from twentyfive to fifty black rings. Crown of the head black; the first and second black mark of the head and neck are joined below by a black longitudinal band, commencing from the chin; snout and side of the head yellow, with a black band running through the eye.

After having examined nearly fifty examples of this species, I have come to the conclusion that the number and width of the black cross bands do not constitute specific characters in these snakes. The length of the tail also varies with the sex. It is a common species, extending from the Bay of Bengal to the Chinese Seas, and to the coasts of $\mathrm{New}$ Zcaland. The largest example I have seen is exactly 5 feet long. (Gïnther.)

Specimens of this smakc are often washed ashore at Bondi after heavy gales. 
Fischers' Sea Snake. Platurus fischeri.

Platurus fischeri. Jan., Iconogr. Descript. in Rev. et Mrag. Zool., 1859. Günther, Rept. of Brit. India, p. 356.

Scales in 19 rows.

Ventrals, 232 to 241.

Total length, 30 inches.

No azygos shield between the posterior frontals; scales of the front part of the trunk in nineteen longitudinal series; ventral shields 232-241. Trunk surrounded by from thirty-three to thirty-six black rings, which are broader than the interspaces. A black band crosses the occiput, and extends forward over the vertical plate, and over the left jaw, but generally, it is not confluent with the next following ring. Upper part of the snout yellow, upper labials black.

Habitat, Australian Seas, near New Guinea, the New Hebrides, \&c.

\section{AIPYSURUS, Lacép.}

Body not much compressed, with trenchant belly, of moderate length. Shields of the head generally divided into more or less numerous smaller pieces; normally only one pair of frontals; nostrils superior, each in a single nasal, the nasals being contiguous to each other. Scales of moderate size, imbricate, smooth or slightly tubercular; ventral shields well developed, with a longitudinal median ridge. Subcaudals broad, entire.

The species of this genus appear rather to belong to the fauna of Polynesia and Australia than to that of British India; no instance of a specimen captured in the seas of the latter countries being on record. (Giinther.)

Eel-Like Sea SNake. Aipysurus anguilliformis.

Thalassopis anguilliformis, Schmidt, Abhandl. Natırw. Hamb. II, p. 76, taf. 1.

Aipysurus anguilliformis, Günther, Rept. of Brit. India, p. 357.

Scales in 17 rows.

Abdominal, 142.

Total length, 24 inches. 
Scales on the highest part of the body in seventeen series, perfectly smooth; ventral shields, 142 . Tail covered laterally with scales similar to those of the trunk, and terminating in a large shield-like scale; shields of the head not, or but little, subdivided; upper parts brownish, with cross bands of yellow black-edged scales; head uniformly blackish. An older example (described by Schmidt) is yellowisl, with numerous rhombic, rather irregular, conflucnt brown spots on the back.

Habitat, Coast of Java and Australian Seas?

Brown Sea Sxake. Aipysurus fuscus.

Aipysurus fuscus, Fischer, Abhandl. Naturw., Hamb. III, p. 33. Günther, Rept. of Brit. India, p. 358.

Scales in 19 rows.

Abdominals, 157 to 166 .

Total length, 39 inches.

Scales on the highest part of the body in nineteen rows; those of the outer series and the ventral shields with small tubercles, which are more distinct in old individuals than in young ones ; ventral shields, 157165-166; scales on the side of the tail larger than those on the body ; shields of the head much subdivided in old cxamples; either uniformly brown, or each scale and ventral shield with a large brownish-black spot near the hind margin.

This species belongs to the fauna of the Australian seas. (Giinther.)

Jukes's Sea Sxake. Aipysurus lavis.

Aipysurus lævis, Lacép. Ann. Alus. IV, pp. 197, 210, pl. 56, fig. 3. Günther, Rept. of Brit. India, p. 358 .

Scales in 21 rows.

Abdominals, 151 to 154 .

Total length, 60 inches.

Scales on the highest part of the body in twenty-one rows, perfectly smooth; ventral shields, 151-(152)-154; scales on the side of the tail elevated, band-like; terminal scale of the tail very large; shiclds of the hcad much subdivided in old examples, which arc uniform brown.

Habitat, Coast of New Caledonia, New Guinea, \&c. 
FMYDOCEPHALUS, Krefft.

Emydocephalus, Krefft, Proc. Zool. Soc., 1869.

Anterior half of the trunk rounded, posterior part compressed, ventral plates well developed; head shielded, gape of mouth short, three upper and three lower labials, the middle one largest, covering nearly the whole upper and lower lip; (scales large and much imbricated, in 16 rows). Occipitals not much larger than the superciliaries, very irregular, with sometimes a plate between them, and much broader than long. Tail much compressed, ending in a large flat scale with two or three denticulations, and a strong keel on each side.

Scales in 16 or 17 rows, hexagonal, much imbricated, and covered with from 5 to 10 or more tubercles, ventral plates much tuberculated, in particular those near the tail.

\section{Tortolse-headed Ringed Sea Snake. Enydocephalus annulatus.}

Emydocephalus annulatus, Krefft, Proc. Zool. Soc., 1869.

Scales in 16 or 17 rows.

Abdominals, 144 .

One anal plate.

Subcaudals, 36 (ending in a broad spine).

Total length, 30 inches.

Head, $\frac{3}{4}$ incli.

Tail, $4 \frac{1}{2}$ inches.

Scales large and imbricated; head small, about as long as broad, covered with rounded plates, which are more or less raised in the middle, and much tuberculated; one or two elongate shields wedged in between the superciliaries; the number of upper and lower labials reduced to three, a middle one of extraordinary size between two small scale-like shields; each scale and plate covered with many small tubercles, and the body encircled by thirty-five black and as many white rings; the white scales upon the back and sides more or less black, and some of the black rings white spotterl.

Habitat, probably the Australian Seas. Two specimens in the Museum collection. 


\section{Tortoise-headed Brown Sea SNake. Emydocephalus tuberculatus.}

Emydocephalus tuberculatus, Krefft, Proc. Zool. Soc., 1869.

Scales in 17 rows.

Abdominal plates, 135 .

One anal plate.

Subcaudal plates, 30.

Total length, 32 inches.

Head, 1 inch.

Tail, $5 \frac{1}{2}$ inches.

Girth, 4 inches.

Head short, but longer than in the previous species; neck rounded; all the other parts of the body compressed, very stout, with strongly compressed tail, ending in a large flat scale or spine divided into three segments, scales very large, hexagonal, the greater portion fully one quarter of an inch wide, much imbricated and tuberculated. Abdominal plates large, with a fold or ridge in the middle, but not keeled; each plate covered with several elongated tubercles. Head shielded, the sutures of the frontals and nasals forming right angles; vertical nearly rounded; superciliaries large, five-sided; occipitals short, much broader than long. Three uppcr and lower labials, the middle one very large, covering nearly the whole gape ; the middle lower labial shield very irregular in form, with one or two indentions. One anterior and two posterior oculars; eye of moderate size. General color uniformly purplish brown; some of the scales on the side mottled with lighter brown spots.

Habitat, probably the Australian Seas; a single specimen in the Museum collection.

\section{- disteira, Lacép.}

Body compressed, of moderate length; head shielded above; a pair of anterior frontals between the nasals which are small. Scales imbricate; ventral shields distinct, but small. 
Dumerm's Sea Snake. Disteira doliata.

Disteira doliata, Lacép. Ann. IIus. IV., p. 199, pl. 57, fig. 2. Dum. \& Bibr., Erpètol. gen. VII, p. 1331.

D. dumerillii, Jan. Iconogr., Descript. in Rev. et MTag. Zool., 1859.

D. doliata, Günther, Reptiles of Brit. India, p. 359.

Scales in 39 or 41 rows.

Abdominals, 234 .

Total length, 33 inches.

One postocular; scales with a short central keel; ventrals bicarnate. Back with broad brownish cross bands, the interspaces of the light ground colour being again divided by narrow brownish transverse streaks, at least on the anterior part of the trunk.

Only the typical specimen of this species is known; no record of the locality where it was obtained has been preserved.

ACALYPTUS, Dum. $\oint$ Bibr.

Posterior half of the trunk compressed, of moderate length. Head covered with scales above, the snout and superciliary region only being shielded. Scales imbricate; ventral shields none.

Bibron's Sea Snake. Acalyptus superciliosus.

Acalyptus superciliosus, Dum. \& Bibr. VII, p. 1340, Günther, Rept. of Brit. India, p. 359.

Scales in 23 rows.

Abdominals?

Total length, 26 inches.

Head small, scarcely longer than broad; body of moderate length, with the anterior portion rather slender. Two labials below the orbit; two postoculars. Nasals forming a suture together; a pair of frontals as large as the nasals; the nostrils are between the nasals and frontals; twentythree series of scales round the neck; scales slightly imbricate, each with a more or less prominent short keel. Trunk with twenty-two black cross bands, tapering on the belly, and about half as broad as the interspaces; each interspace with a faint greyish cross band. Belly with narrow blackish transverse bands, alternating with those descending from the back.

Habitat, South Western Pacific. 
Hydrophis, sp. Daud.

HYDROPHIS.

Posterior part of the body strongly compressed; head short, or of moderate lcngth, shiclded above; only one pair of frontals; nostrils superior, in a single nasal shield, both nasals being contiguous to each other; scales imbricate or not without polish, generally with a tubercle or with a keel; ventral shields very narrow, or quite rudimentary, or entirely absent; lower jaw without notch in front.

Stokes' Sea Snake. Hydrophis stokesii.

(Plate XII, fig. 17.)

Hydrus stokesii, Gray in Stokes' Australia, I, p. 502, tab. 3.

Hydrophis stokesii, Günther, Rept. of Brit. India, p. 363.

Total length, 61 inches.

$4 \frac{1}{2}$ inches high.

10 inches in circumference.

Head rather short and broad; body stout. Two or three labial shields below the eye; two postoculars; chin covered with scales, with no other shields but the mental and labials. Forty-three to forty-seven series of scales round the neck. Scales rather small, much imbricated, keeled, each keel being interrupted in the middle. The ventral shields are replaced by two series of smooth scales, not larger than the scales of the adjoining series, the scales of the two ventral series being arranged opposite to each other. Young specimens and adult males have broad black cross bands, either extending over the back only or entirely surrounding the body. The interspaces between them are generally again divided by a narrow transverse black streak or serics of black spots. Old females are almost entirely uniformly greyish above and whitish below.

Habitat, Northern Coast of Australia.

\section{Belcher's Sea SNake. Hydrophis belcheri.}

Aturia belcheri, Gray, Viper. Snakes, B. MI., p. 46.

Hydrophis belcheri, Günther, Rept. Brit. India, p. 364.

Scales in 25 rows (near neck).

Abdominals, 317.

Total length, 34 inches.

Head, $\frac{1}{2}$ inch.

Tail, $3 \frac{1}{4}$ inches. 
Head of moderate width and size; ncck not very slender, body of moderate length. Rostral shield nearly as broad as long; only the fourth upper labial forms the lower part of the orbit; two postoculars ; three temporal shields on the sidc of each occipital. Two pairs of chin-shields, which are in contact with one another. Twenty-five series of scales round the neck, scales but little imbricated, subtruncated behind, and those on the highest part of the body, as broad as long, each with a short keel. Ventrals, 317 in number, more than twice as broad as the scales of the adjoining series, without keel or tubercle. Four large anal shields. The tail terminates in a very larged forked scale. Back brownish olive, with blackish cross bands, separated by yellowish transverse streaks anteriorly ; these bands become very indistinct towards the middle of the length of the animal. Head and throat blackish; a horse-shoe-like yellowish mark on the crown of the head, resting with its convex anterior portion on the frontal shields. Sides and belly yellowish.

Habitat, coast of New Guinea.

\section{Elegant Sea Snake. Hydrophis elegans.}

\section{(Plate XII, figs. 16, 16a, 16b.)}

Hydrophis doliata, Gray, Zool, MLisc., p. 62, and Viper Snakes, p. 51.

Aturia elegans, Gray, Zool. Misc., p. 61.

Hydrophis elegans, Günther, Rept. Brit. India, p. 369.

Scales in 28 rows.

Abdominals, 330 to 415 .

Anal plates, 6.

Total length, 50 inches.

Head, 7 lines.

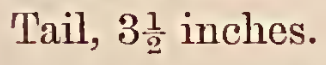

Head rather small and narrow; neck slender, less than one-third of the total length; body elongate. Rostral shield as high as, or higher than, broad; the labial below the eyc is split into two or three pieces; two postoculars. Two pairs of chin shields, the anterior of which are in contact with each other. Twenty-cight series of scales round the ncck. Scales imbricate, kcelcd, rhombic, those on the highest part of the body about as high as long. Ventrals twice or thrice as broad as the scales of the adjoining series, bitubercular, and from 330-415 in number. Six anal shields. Trunk with from forty-two to forty-cight black or blackish olive cross 
bands, rounded laterally, extending downwards to the middle of the sides, and rather broader than the interspaces of the ground-color; belly with a blaek longitudinal band. Hcad entirely black, separated from the first cross band by a narrow white ring. The young specimen has a transverse series of small black spots in the middle of each interspace betwcen the black eross bands; and an irregular series of small round black spots runs along cach side of the belly.

Habitat, coast of New South Wales and Qucensland.

Ered Sea Sxake. Hydropliis ocellata.

(Plate XII, figs. 15, 15a.)

Hydrophis ocellata, Gray, Viper. Snates, p. 53, and Günther, Rept. Birt. India, p. 378, pi. XXV, figs. P, P.

Scales in 35 to 41 rows.

Abdominals, 296 to 334 .

Total length, 44 inches.

Head (cleft of mouth), $\frac{7}{8}$ inch.

Tail, 5 inches.

Head rather short and broad; anterior and posterior parts of the body moderately stout; two pairs of chin shields, the anterior of which are in contact with each other; two postoculars, thirty-five to forty-onc series of scales round the neck; ventral shields distinct, but not twice as broad as the scales of the adjoining series, 296-334 in number; six præanal shields, the outer of which are the largest; scalcs of the young smooth-of the adult with a short tubercular keel; back with from thirtytwo to thirty-four blackish cross bands, the anterior of which are quadrangular, and separated by straight, very narrow, transverse, whitish-lines; the middle and posterior are rounded elliptical, each with lighter centre; a smaller, transverse, blackish spot behind each large elliptical cross band; a series of ovate blackish ocelli, each with lighter centre, runs along the side of the back, the ocelli being alternate with the dorsal bands; two other series of small, round, altermate spots along the lower side; belly with numerous blackish dots; head uniformly brownish olive; tail with two rows of blackish cross bars, the one ascending from the lower sidc, the other descending from the upper; the bars of both sicles altcrnate with eaeh other.

Habitat; the Australian Scas. 
ENHYDRINA. Gray.

Differing from Hydrophis only by having a deep, longitudinal notch in front of the lower jaw.

Only one species is known.

Bengat Sea Snake. Enhydrina bengalensis. p. 381.

Enhydrina bengalensis, Gray, Viper. Snakes, p. 48, and Günther, Rept. Brit. India,

Scales in 48 rows.

Abdominals, 284 to 314 .

Total length, 48 inches.

New-born young snake, $10 \frac{1}{2}$ inches.

Habitat, from the Sea of Bengal to the Coast of New Guinea.

Pelamis, sp. Daud.

PEIAIMIS.

Head flat, with very long, spatulate snout; neck rather stout; body of moderate length. Nasal shields contiguous, longer than broad, pierced by the nostril posteriorly; only one pair of frontals. Scales not imbricate, not polished, tubercular or concave. Ventral shields none, or very narrow. Lower jaw without notch in front.

Yelilow-belited Sea SNake. Pelamis bicolor.

Russell, Ind. Serp., I, p. 47, pl. 41.

(Plate XII, fig. 19.)

Hydrus bicolor, Schneid, Hist. Amph., p. 242. Cantor, Mal. Rept., p. 135.

Pelamis bicolor, Daud., Rept., VII, p. 366. Gray, Viper. Snakes, p. 41. Fischer, Abhandl. Naturw. Hamb., 1856, p. 61. Günther, Rept. Brit. India, p. 382.

Hydrophis variegata, Schleg. Faun. Jap., tab. 8.

- pelamis, Schleg. Phys. Serp., II, p. 508, pl. 18, figs. 13-15.

Pelamis ornata, Gray, Tiper. Suakes, p. 43.

Scales in 45 to 51 rows.

Abdominals (or scales from mouth to vent longitudinally), 378 to 440 .

Total length, 36 inches.

Two or three postorbitals. Neck surrounded by from forty-five to fifty-one longitudinal series of scales. From 378 to 440 scales in a lateral longitudinal series, between the angle of the mouth and the vent. Coloration variable. 
Var. a. The upper part of the head and the back are uniformly black, the sides and belly uniformly brownish olive; both color's are sharply defined, and sometimes separated by a yellow band. Tail with large black spots.

Var. $\beta$. The black of the back and the brown of the sides are separated by a yellow band, as in Var. a, but there is another black latera band below the yellow one, broken up posteriorly into a series of large round black spots.

Var. $\gamma$. The black band of the back is rather narrow, becomes sinuous on or behind the middle of the length of the body, and is broken up posteriorly into a dorsal series of rhombic, and more or less confluent spots, extending downwards on the sides. Sides and belly with rather irregular series of rounded black or brown spots. This variety is intermediate between Var. $\beta$ and Var. $\delta$, and has been named sinuata.

Var. s. Yellow, with about fifty brown black-edged cross-bands, extending ncarly to the belly, which again is crossed by narrow vertical brownish-black streaks, alternating with the dorsal bands. Some of the dorsal bands are confluent, forming a zigzag band. Head yellow, variegated with black: H. variegata, Schleg.; $P$. ornata, Gray; varietas alternans, Fischer.

This species is one of the most common Sea Snakes, and has the widest geographical range of all the species of this family ; it appears to be found throughout the tropical and subtropical parts of the Indian and Pacific Occans. We have received specimens captured off the coast of Madagascar, in the sea between Australia and New Zealand; and the Sea Snakes seen off the coast of Panama appear to belong to this species. Fischer $(l, c$.$) mentions specimens preserved in the Berlin Museum, and$ marked "West Coast of Mexico," and the British Nuseum has received a specimen said to be from Panama. None of the specimens we have examined exceed a length of three feet. (Gïnther.)

The present species occurs more frequently on the Australian Coast than any other Sea Snake; several gravid females were captured in Botany Bay which contained from four to six young of considerable size. During heavy gales many specimens are thrown ashore along the coast; they have also been taken in the harbour of Port Jackson. 


\section{A P P ENDIX.}

The following five new species are enumerated by Dr. Günther, in his valuable "Record of Zoological Literature":-

\section{. TYPHLOPS.**}

Trphlops aüntheri. (Peters.)

Monatsher. Akad. Wiss. Berlin, 1865, p. 259, fig. 1. From Cape York.

Trphlops WIEdII. (Peters.)

L.e., 1867, p. 24. From Brisbane.

TrpHlops (Onychocephalus) uvguirostris. (Peters.)

L.e., 1867, p. 708, fig. 3. From Queensland.

\section{PSEUDFCHIS.}

Pseudechis scuteluatus. (Peters.)

Monatsber, 1S67, p. 710. From Rockhampton.

\section{HOPIOCEPHALUS}

Hoplocephatus Maculatus. (Steind.)

Novara, Rept., p. 81, tab. 3.

\section{HYDROPHIS.}

\section{HrDROPHIS STOKESII ? (Gray.)}

Capt. Edwards has presented a very large Sea Snake, of a uniform black color, which is fully as large as the specimen measured by Dr. Günther, viz., about 5 feet long, 5 inches high, and 11 inches in circumference. The specimen was captured on the North Coast.

\footnotetext{
* Professor Peters considers-

Typhlops australis (Gray), and

preissi (Jan), as identical ; and also,

nigrescens (Griy),

polygrammicus (Schleg),

rtipellii $(J a m)$

temminckii (Jan), as one and the same species.
} 


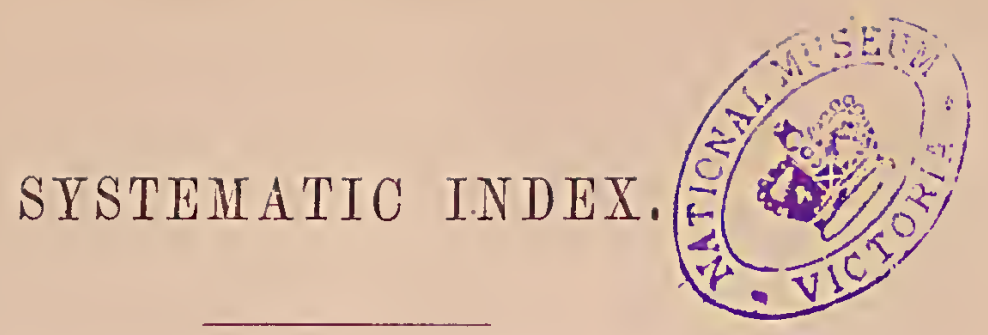

The names of the authors are marked who first gave the specifie denomination. The species which are desiderata to the Museum collection are marked with a *

FAM. TYPILOPIDA.

Trphlops. Dum. and Bibr.

Page.

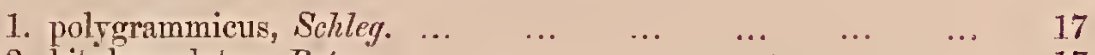

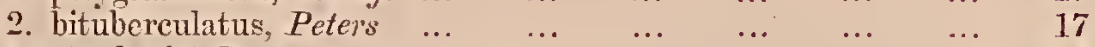

$\begin{array}{llllllll}\text { 3. güntheri, }{ }^{*} \text { Peters ... } & \ldots & \ldots & \ldots & \ldots & \ldots & \ldots & 17 \\ \end{array}$

4. nigresceus, Gray $\ldots \begin{array}{llllllll}\ldots & \ldots & \ldots & \ldots & \ldots & \ldots & \ldots & 18\end{array}$

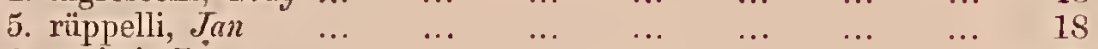

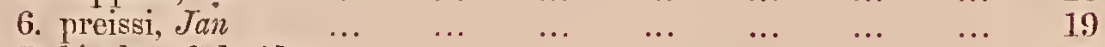

$\begin{array}{lllllllll}\text { 7. bicolor, Schmidt } & \ldots & \ldots & \ldots & \ldots & \ldots & \ldots & \ldots & 19\end{array}$

$\begin{array}{lllllllll}\text { 8. australis, Gray } & \ldots & \ldots & \ldots & \ldots & \ldots & \ldots & \ldots & 18\end{array}$

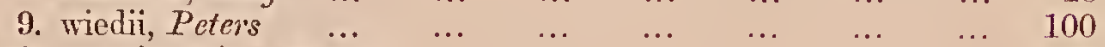

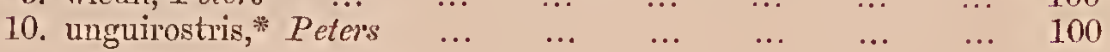

FAM. COLUBRID AN.

Coroyeuta. Laur.

$\begin{array}{llllllllll}\text { 1. australis, } \text { * Gthr. } & \ldots & \ldots & \ldots & \ldots & \ldots & \ldots & \ldots & 20\end{array}$

FAM. NATRICIDAE.

Tromidonotus. Kuhl.

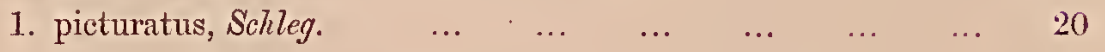

FAI. HOIIALOPSIDAE.

Cerberus. Cuvier.

$\begin{array}{lllllllll}\text { 1. australis, * Gray } & \ldots & \ldots & \ldots & \ldots & \ldots & \ldots & \ldots & 22\end{array}$

Mrrox. Gray.

$\begin{array}{llllllll}\text { 1. richardsonii*, Gray } & \ldots & \ldots & \ldots & \ldots & \ldots & \ldots & 23\end{array}$

FAM. DENDROPHIDA.

Dexprophis. Boie.

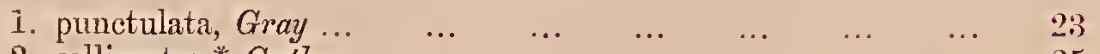

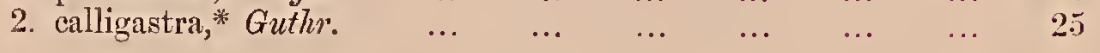


FAM. DIPSADIDAE.

Page.

DiPsas. Auct.

1. fusca, Gray

26

FAM. PYTHONID 2 .

Morelia. Gray.

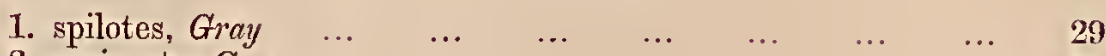

2. variegata, Gray $\begin{array}{llllllll}\ldots & \ldots & \ldots & \ldots & \ldots & \ldots & \ldots & 29 \\ & & & & & & & \end{array}$

Aspidiotes. Kreflt.

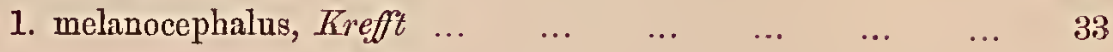

Liasis. Gray.

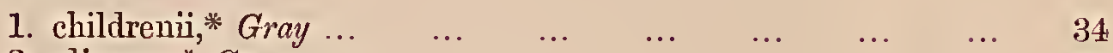

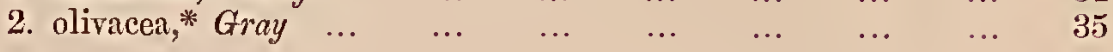

Nardoa. Gray.

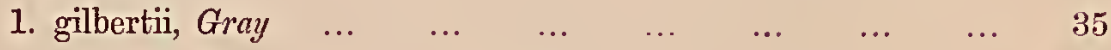

FAM. ELAPIDAE.

Diemenia. Gray.

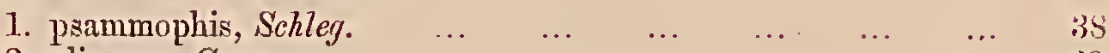

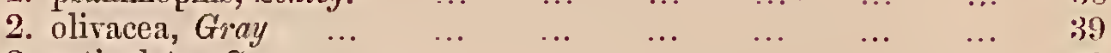

$\begin{array}{llllllllll}\text { 3. reticulata, Gray } & \ldots & \ldots & \ldots & \ldots & \ldots & \ldots & \ldots & \ldots & 40\end{array}$

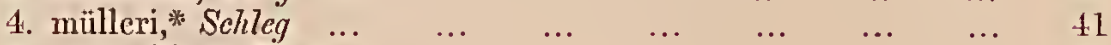

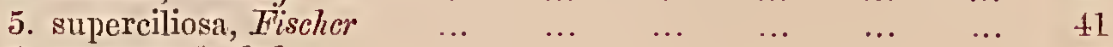

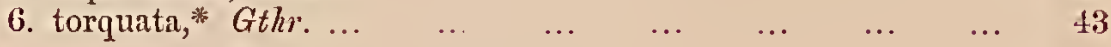

Pseudonaja. Gthr.

1. muchalis, ${ }^{*}$ Gthr.

Pseudechis. Wagler.

$\begin{array}{lllllllll}\text { 1. porphyriacus, Shaw } & \ldots & \ldots & \ldots & \ldots & \ldots & \ldots & \text { t6 }\end{array}$

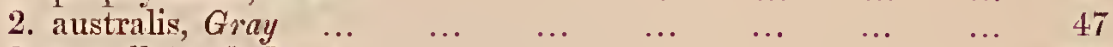

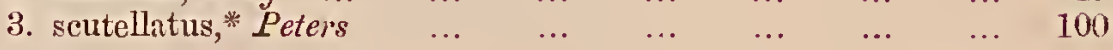

Brachisoma. Gthr.

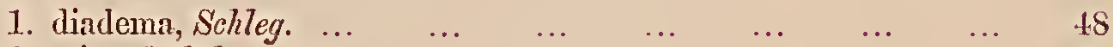

$\begin{array}{lllllllll}\text { 2. } \text { triste, }^{*} \text { Gthr. } & \ldots & \ldots & \ldots & \ldots & \ldots & \ldots & \ldots & 50\end{array}$

Furisa. Dum. and Bibr.

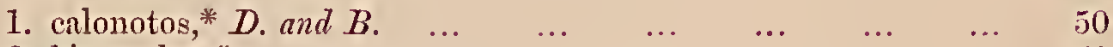

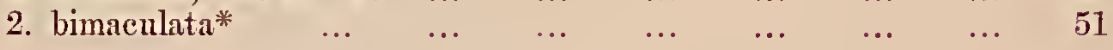

BRACHYUROPHIS. Gthe.

$\begin{array}{llllllllll}\text { 1. australis, Krefft } & \ldots & \ldots & \ldots & \ldots & \ldots & \ldots & \ldots & 52\end{array}$ 
Hoplocephalus. Cuvier.

Page.

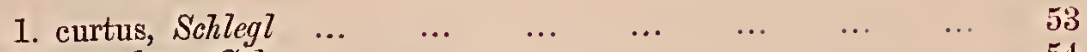

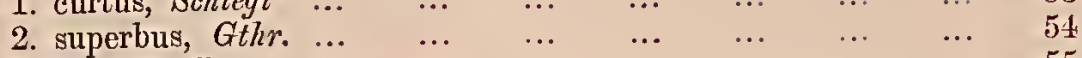

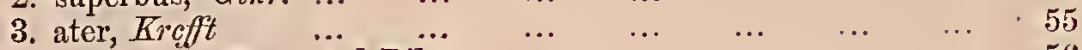

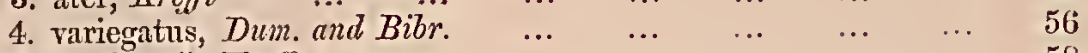

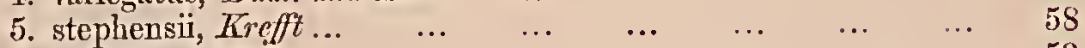

$\begin{array}{llllllll}\text { 6. pallidiceps, Githr. } & \ldots & \ldots & \ldots & \ldots & \ldots & \ldots & 59\end{array}$

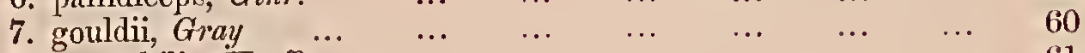

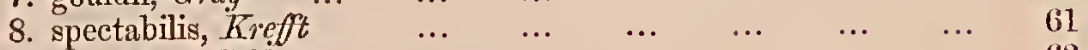

$\begin{array}{llllllll}\text { 9. coronatus, Schleg. } & \ldots & \ldots & \ldots & \ldots & \ldots & \ldots & 61\end{array}$

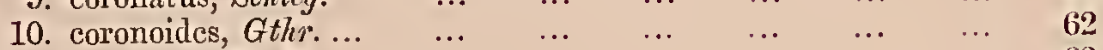

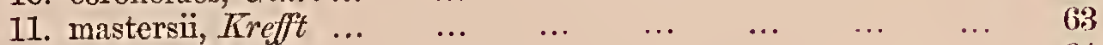

$\begin{array}{lllllllll}\text { 12. signatus, } \operatorname{Jan} & \ldots & \ldots & \ldots & \ldots & \ldots & \ldots & \ldots & 64\end{array}$

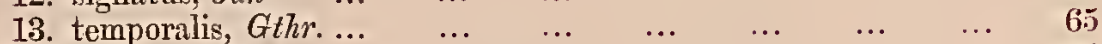

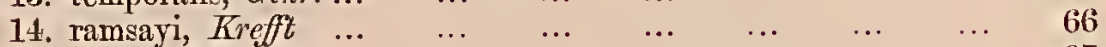

$\begin{array}{lllllllll}\text { 15. minor, Gthr. } & \ldots & \ldots & \ldots & \ldots & \ldots & \ldots & \ldots & 67\end{array}$

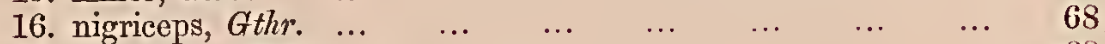

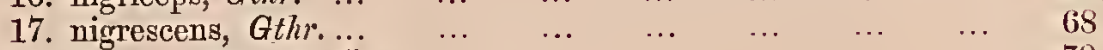

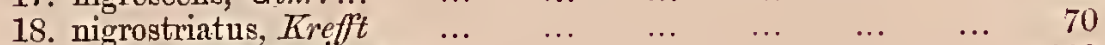

$\begin{array}{lllllll}\text { 19. maculatus, }{ }^{*} \text { Steindachner... } & \ldots & \ldots & \ldots & \ldots & \ldots & 100\end{array}$

TrOPIDECHIS. Gthr.

$\begin{array}{lllllllll}\text { 1. } \text { carinata, } \text { Krefft } & \ldots & \ldots & \ldots & \ldots & \ldots & \ldots & \ldots & 71\end{array}$

Petrodicion. Krefft.

$\begin{array}{lllllllll}\text { 1. cucullatum, Gthr. } & \ldots & \ldots & \ldots & \ldots & \ldots & \ldots & 72\end{array}$

Cacophis. Gthr.

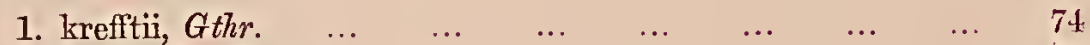

$\begin{array}{lllllllll}\text { 2. fordei, Krefft } & \ldots & \ldots & \ldots & \ldots & \ldots & \ldots & \ldots & 74 \\ \end{array}$

$\begin{array}{lllllllll}\text { 3. harriettæ, Krefft } & \ldots & \ldots & \ldots & \ldots & \ldots & \ldots & \ldots & 76\end{array}$

$\begin{array}{llllllll}\text { 4. blackmanii, Krefft } & \ldots & \ldots & \ldots & \ldots & \ldots & \ldots & 77\end{array}$

Vermicelll. Gray.

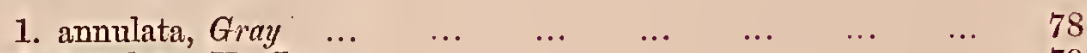

$\begin{array}{lllllllll}\text { 2. lunulata, Krefft } & \ldots & \ldots & \ldots & \ldots & \ldots & \ldots & \ldots & 78 \\ & & \ldots & \ldots & \ldots & \ldots & \ldots & \ldots & 79\end{array}$

ACANThophis. Daud.

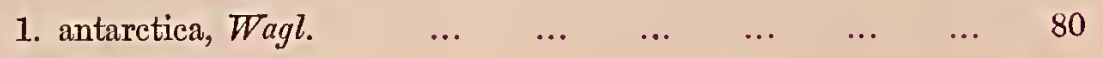

Denisonia. Krefft.

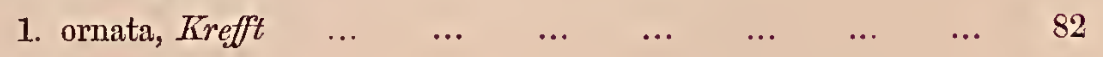

FAM. HYDROPHID XE.

Platurus. Latr.

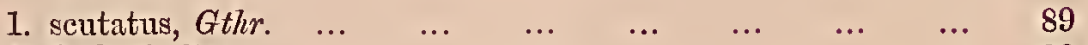

$\begin{array}{lllllllll}\text { 2. fischeri, } \operatorname{Jan} & \ldots & \ldots & \ldots & \ldots & \ldots & \ldots & \ldots & 90\end{array}$ 
Arprsunus. Tacép.

Page.

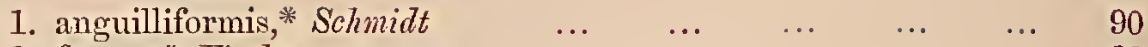

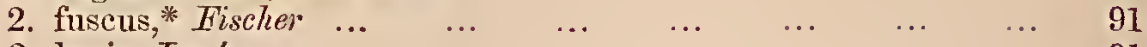

$\begin{array}{lllllllll}\text { 3. lævis, Lacép } & \ldots & \ldots & \ldots & \ldots & \ldots & \ldots & \ldots & 91\end{array}$

Emroocepitalus. Trefft.

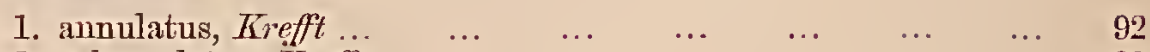

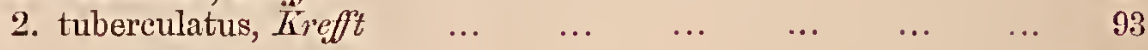

Disteiri. Lacép.

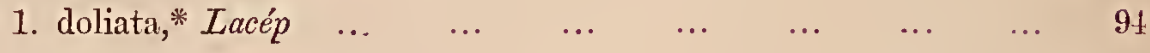

Acaltrpuses Dum. and Bibr.

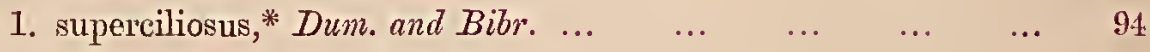

Hronopiess. Dand.

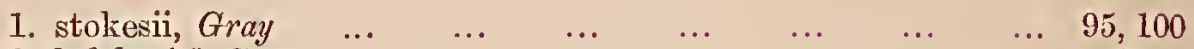

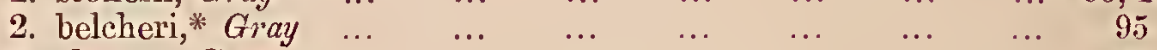

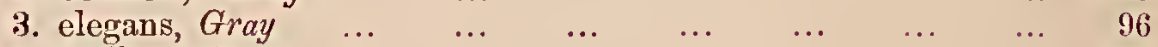

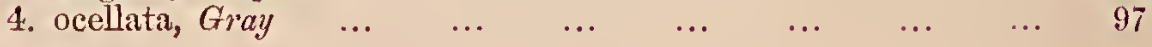

ENHYDRIYA. Gray.

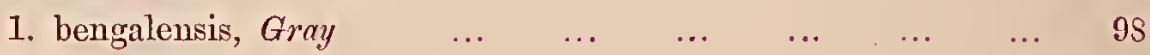

Pelajirs. Daud.

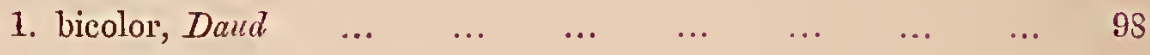




\section{GEOGRAPHICAL INDEX.}

\section{NEW SOUTH WALES.}

\section{ININOCUOUS SNAIKES.}

Schlegel's Buixd Stike.

$\begin{array}{lllllllll}\text { Typhlops polygrammicus } & \ldots & \ldots & \ldots & \ldots & \ldots & \ldots & 17\end{array}$

Grar's Butid Sxike.

$\begin{array}{llllllllll}\text { Typhlops nigrescens } & \ldots & \ldots & \ldots & \ldots & \ldots & \ldots & \ldots & 18\end{array}$

R̈̈PPELL'S BLIND SYAKE.

$\begin{array}{llllllllll}\text { Typhlops rüppelli } & \ldots & \ldots & \ldots & \ldots & \ldots & \ldots & \ldots & 18\end{array}$

Preiss' Blisto Srake.

$\begin{array}{lllllllllll}\text { Typhlops preissi } \ldots & \ldots & \ldots & \ldots & \ldots & \ldots & \ldots & \ldots & 19\end{array}$

Scinmot's Brind Srake.

$\begin{array}{lllllllll}\text { Typhlops bicolor } \ldots & \ldots & \ldots & \ldots & \ldots & \ldots & \ldots & \ldots & 19\end{array}$

dustraliay Tropidorotus.

$\begin{array}{lllllllll}\text { Tropidonotus picturatus... } & \ldots & \ldots & \ldots & \ldots & \ldots & \ldots & 20\end{array}$

Grfex Tree Srake.

$\begin{array}{llllllllll}\text { Dendrophis punctulata } \ldots & \ldots & \ldots & \ldots & \ldots & \ldots & \ldots & 23\end{array}$

Brow Tree Sxake,

$\begin{array}{llllllllll}\text { Dipsas fusca } & \ldots & \ldots & \ldots & \ldots & \ldots & \ldots & \ldots & \ldots & 26\end{array}$

DIAMOND STAKE.

$\begin{array}{llllllllll}\text { Morelia spilotes } & \ldots & \ldots & \ldots & \ldots & \ldots & \ldots & \ldots & \ldots & 29\end{array}$

Carpet Srake.

$\begin{array}{lllllllll}\text { Morelia variegata } & \ldots & \ldots & \ldots & \ldots & \ldots & \ldots & \ldots & 31\end{array}$

VENOIMOUS SNAIKES.

Grey Srake.

$\begin{array}{lllllllll}\text { Diemenia reticulata } & \ldots & \ldots & \ldots & \ldots & \ldots & \ldots & \ldots & 40\end{array}$

Brown Srake.

$\begin{array}{lllllllll}\text { Diemenia superciliosa } & \ldots & \ldots & \ldots & \ldots & \ldots & \ldots & \ldots & \text { H }\end{array}$

MÜLLER'S STAKE.

$\begin{array}{lllllllll}\text { Diemenia mülleri }(?) & \ldots & \ldots & \ldots & \ldots & \ldots & \ldots & \ldots & 41\end{array}$ 
Buack SNAKe.

Page.

$\begin{array}{lllllllll}\text { Pseudechis porphyriacus } & \ldots & \ldots & \ldots & \ldots & \ldots & \ldots & 46\end{array}$

ScarteT-SPOTIED SNAKE.

$\begin{array}{llllllllll}\text { Brachysoma diadema } & \ldots & \ldots & \ldots & \ldots & \ldots & \ldots & \ldots & 48\end{array}$

Austratmat Short-tareed Swake.

$\begin{array}{lllllllll}\text { Brachyurophis australis } & \ldots & \ldots & \ldots & \ldots & \ldots & \ldots & 52\end{array}$

BROWN-BANDED SYaKe.

$\begin{array}{llllllllll}\text { Hoplocephalus curtus } & \ldots & \ldots & \ldots & \ldots & \ldots & \ldots & \ldots & 53\end{array}$

LARGE-SCATED SFAKE.

$\begin{array}{lllllllll}\text { Hoplocephalus superbus... } & \ldots & \ldots & \ldots & \ldots & \ldots & \ldots & 54\end{array}$

Broad-meaded Srake.

$\begin{array}{lllllllll}\text { Hoplocephalus variegatus } & \ldots & \ldots & \ldots & \ldots & \ldots & \ldots & 56\end{array}$

Stephens' Banded Srake.

$\begin{array}{lllllllll}\text { Hoplocephalus stephensii } & \ldots & \ldots & \ldots & \ldots & \ldots & \ldots & 58\end{array}$

Pale-meaded Srate.

$\begin{array}{lllllllll}\text { Hoplocephalus pallidiceps } & \ldots & \ldots & \ldots & \ldots & \ldots & \ldots & 59\end{array}$

Gould's Srake.

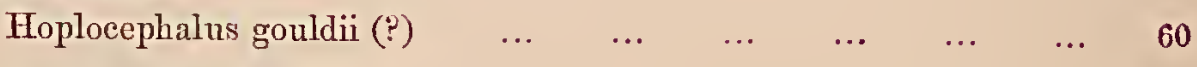

BLACK-Beltied SNake.

$\begin{array}{lllllllll}\text { Hoplocephalus signatus ... } & \ldots & \ldots & \ldots & \ldots & \ldots & \ldots & 64\end{array}$

RAMSAX's STAKE.

$\begin{array}{llllllllll}\text { Hoplocephalus ramsayi } & \ldots & \ldots & \ldots & \ldots & \ldots & \ldots & \ldots & 66\end{array}$

BLACK-YAPED SNAKE.

$\begin{array}{llllllllll}\text { Hoplocephalus nigriceps... } & \ldots & \ldots & \ldots & \ldots & \ldots & \ldots & 68\end{array}$

BuACK-BACKed STAKE.

$\begin{array}{lllllllll}\text { Hoplocephalus nigrescens } & \ldots & \ldots & \ldots & \ldots & \ldots & \ldots & 68\end{array}$

Chateive River Srake.

$\begin{array}{llllllllll}\text { Tropidechis carinata } & \ldots & \ldots & \ldots & \ldots & \ldots & \ldots & \ldots & 71\end{array}$

ReD-Bextied Srake.

$\begin{array}{llllllllll}\text { Petrodymon cuculatum } & \ldots & \ldots & \ldots & \ldots & \ldots & \ldots & \ldots & 72\end{array}$

KREFF's SNake.

$\begin{array}{llllllllll}\text { Cacophis krefitii } \ldots & \ldots & \ldots & \ldots & \ldots & \ldots & \ldots & \ldots & 74\end{array}$

Black and White Rivged Srake.

$\begin{array}{llllllllll}\text { Vermicella annulata } & \ldots & \ldots & \ldots & \ldots & \ldots & \ldots & \ldots & 78\end{array}$

Death Adder.

$\begin{array}{llllllllll}\text { Acanthophis antarctica } & \ldots & \ldots & \ldots & \ldots & \ldots & \ldots & \ldots & 80\end{array}$ 


\section{VICTORIA.}

\section{INNOCUOUS SNAKES.}

Preiss' Butind Stake.

$\begin{array}{lllllllll}\text { Typhlops preissii ... } & \ldots & \ldots & \ldots & \ldots & \ldots & \ldots & \ldots & 19\end{array}$

Schimts's Butxo Srake.

$\begin{array}{llllllllll}\text { Typhlops bicolor } \ldots & \ldots & \ldots & \ldots & \ldots & \ldots & \ldots & \ldots & 19\end{array}$

Greex Tree Srake.

$\begin{array}{llllllllll}\text { Dendrophis punctulata } & \ldots & \ldots & \ldots & \ldots & \ldots & \ldots & \ldots & 23\end{array}$

Carpet Srake.

$\begin{array}{llllllllll}\text { Morelia variegata... } & \ldots & \ldots & \ldots & \ldots & \ldots & \ldots & \ldots & 31\end{array}$

\section{VENOMOUS SNAKES.}

Grey Srake.

$\begin{array}{lllllllll}\text { Diemenia reticulata } & \ldots & \ldots & \ldots & \ldots & \ldots & \ldots & \ldots & 40\end{array}$

Browx Sxake.

$\begin{array}{lllllllll}\text { Diemenia supercilios: } & \ldots & \ldots & \ldots & \ldots & \ldots & \ldots & \ldots & 41\end{array}$

BLACK SNIKE.

$\begin{array}{llllllll}\text { Pseudechis porphyriacus... } & \ldots & \ldots & \ldots & \ldots & \ldots & \ldots & 46\end{array}$

Browi-Baxded or Tiger Siake.

$\begin{array}{lllllllll}\text { Hoplocephalus curtus } & \ldots & \ldots & \ldots & \ldots & \ldots & \ldots & \ldots & 53\end{array}$

BROAD-SCALED STAKE.

$\begin{array}{lllllllll}\text { Hoplocephalus superbus... } & \ldots & \ldots & \ldots & \ldots & \ldots & \ldots & 54\end{array}$

Brack-Beldted Srake.

$\begin{array}{lllllllll}\text { Hoplocephalus signatus } & \ldots & \ldots & \ldots & \ldots & \ldots & \ldots & \ldots & 64\end{array}$

Black axd White Rivged Srake.

$\begin{array}{lllllllll}\text { Vermicella annulata } & \ldots & \ldots & \ldots & \ldots & \ldots & \ldots & \ldots & 78\end{array}$

Death AdDer.

$\begin{array}{lllllllll}\text { Acanthophis antaretical } & \ldots & \ldots & \ldots & \ldots & \ldots & \ldots & \ldots & s 0\end{array}$

\section{SOUTH AUS'IRALIA.}

INNOCUOUS SNAKES.

Peters' Buñi Srinke.

$\begin{array}{llllllllll}\text { Typhlops bituberculatus... } & \ldots & \ldots & \ldots & \ldots & \ldots & \ldots & 17\end{array}$

Carpet Sxakf.

$\begin{array}{llllllllll}\text { Morelia variegata } & \ldots & \ldots & \ldots & \ldots & \ldots & \ldots & \ldots & 31\end{array}$ 


\section{VENOMOUS SNAKES.}

Grex SNake.

Page.

$\begin{array}{llllllllll}\text { Diemenia reticulata } & \ldots & \ldots & \ldots & \ldots & \ldots & \ldots & \ldots & 40\end{array}$

Brows Srake.

$\begin{array}{llllllllll}\text { Diemenia superciliosa } & \ldots & \ldots & \ldots & \ldots & \ldots & \ldots & \ldots & 41\end{array}$

Btack Stake.

$\begin{array}{lllllllll}\text { Pseudechis porphyriacus } & \ldots & \ldots & \ldots & \ldots & \ldots & \ldots & 46\end{array}$

Brown-barded SNaKe.

$\begin{array}{llllllllll}\text { Hoplocephalus curtus } & \ldots & \ldots & \ldots & \ldots & \ldots & \ldots & \ldots & 53\end{array}$

LARGE-sCALED SFAKE.

$\begin{array}{lllllllll}\text { Hoplocephalus superbus } & \ldots & \ldots & \ldots & \ldots & \ldots & \ldots & 51\end{array}$

FuINDERs' STAKe.

$\begin{array}{llllllllll}\text { Hoplocephalus ater } & \ldots & \ldots & \ldots & \ldots & \ldots & \ldots & \ldots & 55\end{array}$

GouLd's STake.

$\begin{array}{llllllllll}\text { Hoplocephalus gouldii } & \ldots & \ldots & \ldots & \ldots & \ldots & \ldots & \ldots & 60\end{array}$

Port Lincolis SNake.

$\begin{array}{lllllllll}\text { Hoplocephalus spectabilis } & \ldots & \ldots & \ldots & \ldots & \ldots & \ldots & 61\end{array}$

Crowred Srake.

$\begin{array}{lllllllll}\text { Hoplocephalus coronatus } & \ldots & \ldots & \ldots & \ldots & \ldots & \ldots & 62\end{array}$

Misters' Srake.

$\begin{array}{llllllllll}\text { Hoplocephalus mastersii... } & \ldots & \ldots & \ldots & \ldots & \ldots & \ldots & 63\end{array}$

Temporal Desert Srake.

$\begin{array}{lllllllll}\text { Hoplocephalus temporalis } & \ldots & \ldots & \ldots & \ldots & \ldots & \ldots & 65\end{array}$

Desert Srake.

$\begin{array}{llllllllll}\text { Hoplocephalus minor } & \ldots & \ldots & \ldots & \ldots & \ldots & \ldots & \ldots & 67\end{array}$

Black axd White RLiged Srake.

$\begin{array}{llllllllll}\text { Termicella annulata } & \ldots & \ldots & \ldots & \ldots & \ldots & \ldots & \ldots & 78\end{array}$

\section{WEST AUSTRALIA.}

\section{ININOCUOUS SNAKES.}

West Austriliay Buivd Syake.

$\begin{array}{llllllllll}\text { Typhlops australis } & \ldots & \ldots & \ldots & \ldots & \ldots & \ldots & \ldots & 18\end{array}$

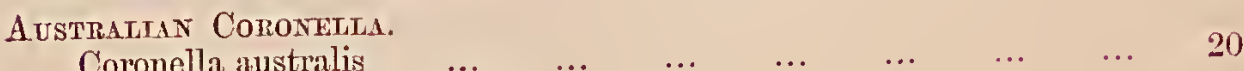

Richardson's Water SNake.

$\begin{array}{llllllllll}\text { Mfyron lichardsonii } & \ldots & \ldots & \ldots & \ldots & \ldots & \ldots & \ldots & 23\end{array}$

Carpet Srate.

$\begin{array}{llllllllll}\text { Morelia variegatal } & \ldots & \ldots & \ldots & \ldots & \ldots & \ldots & \ldots & 31\end{array}$ 


\section{VENOMOUS SNAKHS.}

Brown Srake.

Page.

$\begin{array}{llllllllll}\text { Diemenia superciliosa } & \ldots & \ldots & \ldots & \ldots & \ldots & \ldots & \ldots & \$ 1\end{array}$

North Australiax Baxded Snake.

$\begin{array}{llllllllll}\text { - Pseudonaja muchalis } & \ldots & \ldots & \ldots & \ldots & \ldots & \ldots & \ldots & 44\end{array}$

ScarteT-SPOTTEd SNake.

$\begin{array}{llllllllll}\text { Brachysoma diadema } & \ldots & \ldots & \ldots & \ldots & \ldots & \ldots & \ldots & 48\end{array}$

Verresux's Furnis.

$\begin{array}{llllllllll}\text { Furina bimaculata } & \ldots & \ldots & \ldots & \ldots & \ldots & \ldots & \ldots & 51\end{array}$

Brown-BaTded SraKe.

$\begin{array}{llllllllll}\text { Hoplocephalus curtus } & \ldots & \ldots & \ldots & \ldots & \ldots & \ldots & \ldots & 53\end{array}$

LARGE-SCALED SNAKE.

$\begin{array}{lllllllll}\text { Hoplocephalus superbus... } & \ldots & \ldots & \ldots & \ldots & \ldots & \ldots & 54\end{array}$

GouLD's Srake.

$\begin{array}{llllllllll}\text { Hoplocephalus gouldii } & \ldots & \ldots & \ldots & \ldots & \ldots & \ldots & \ldots & 60\end{array}$

Crowsed Srake.

$\begin{array}{lllllllll}\text { Hoplocephalus coromatus } & \ldots & \ldots & \ldots & \ldots & \ldots & \ldots & 62\end{array}$

Temporal Deshat SNike.

$\begin{array}{lllllllll}\text { Hoplocephalus temporalis } & \ldots & \ldots & \ldots & \ldots & \ldots & \ldots & 65\end{array}$

Desert Srake.

$\begin{array}{lllllllll}\text { Hoplocephalus minor } & \ldots & \ldots & \ldots & \ldots & \ldots & \ldots & \ldots & 67\end{array}$

RINGED SNAKE.

$\begin{array}{llllllllll}\text { Vermicella ammulata } & \ldots & \ldots & \ldots & \ldots & \ldots & \ldots & \ldots & 78\end{array}$

\section{QUEENSLAND.}

ININOCUOUS . SINAKEIS.

Schlegel's Bhind Shake.

$\begin{array}{lllllllll}\text { Typhlops polygrammicus } & \ldots & \ldots & \ldots & \ldots & \ldots & \ldots & 17\end{array}$

Günther's BLind SNake.

$\begin{array}{llllllllll}\text { Typhlops güntheri } & \ldots & \ldots & \ldots & \ldots & \ldots & \ldots & \ldots & 17\end{array}$

Wied's Buivd Srake.

$\begin{array}{lllllllllll}\text { Typhlops wiedii } & \ldots & \ldots & \ldots & \ldots & \ldots & \ldots & \ldots & \ldots & 100\end{array}$

Queevsuavd Buind Srake.

$\begin{array}{llllllllll}\text { Typhlops unguirostris } & \ldots & \ldots & \ldots & \ldots & \ldots & \ldots & \ldots & 100\end{array}$

Australtan Fresi-water Snake.

$\begin{array}{llllllllll}\text { Tropidonotus picturatus } & \ldots & \ldots & \ldots & \ldots & \ldots & \ldots & 20\end{array}$

Australiaf Bockadam.

$\begin{array}{llllllllll}\text { Cerberus australis } & \ldots & \ldots & \ldots & \ldots & \ldots & \ldots & \ldots & 22\end{array}$ 
Green Tree Srake.

$\begin{array}{lllllllll}\text { Dendrophis } \text { punctulata } & \ldots & \ldots & \ldots & \ldots & \ldots & \ldots & \ldots & 23\end{array}$

Northery Tree Sxake.

$\begin{array}{llllllllll}\text { Dendrophis calligastra } & \ldots & \ldots & \ldots & \ldots & \ldots & \ldots & \ldots & 25\end{array}$

Brows Tree Srake.

$\begin{array}{lllllllllll}\text { Dipsas fusca } & \ldots & \ldots & \ldots & \ldots & \ldots & \ldots & \ldots & \ldots & 26\end{array}$

Carpet Stake.

$\begin{array}{llllllllll}\text { Morelia variegata } & \ldots & \ldots & \ldots & \ldots & \ldots & \ldots & \ldots & 31\end{array}$

Black-headed SNake.

$\begin{array}{lllllllll}\text { Aspidiotes melanocephalus } & \ldots & \ldots & \ldots & \ldots & \ldots & \ldots & 33\end{array}$

Chimdrex's Rock Srake.

$\begin{array}{llllllllll}\text { Liasis childrenii } & \ldots & \ldots & \ldots & \ldots & \ldots & \ldots & \ldots & \ldots & 34\end{array}$

Outre.green Rock STake.

$\begin{array}{lllllllllll}\text { Thiasis olivacea } & \ldots & \ldots & \ldots & \ldots & \ldots & \ldots & \ldots & \ldots & 35\end{array}$

Gilbent's Rock Srake.

$\begin{array}{llllllllll}\text { Nardoa gilbertii } & \ldots & \ldots & \ldots & \ldots & \ldots & \ldots & \ldots & \ldots & 35\end{array}$

VENOMOUS SNAKES.

Schiteget's Srake.

$\begin{array}{llllllllll}\text { Diemenia psammophis } & \ldots & \ldots & \ldots & \ldots & \ldots & \ldots & \ldots & 38\end{array}$

SPOTTED-Headed Syake.

$\begin{array}{llllllllll}\text { Diemenia olivacea } & \ldots & \ldots & \ldots & \ldots & \ldots & \ldots & \ldots & 39\end{array}$

Grex Sxike.

$\begin{array}{llllllllll}\text { Diemenia reticulata } & \ldots & \ldots & \ldots & \ldots & \ldots & \ldots & \ldots & 40\end{array}$

MÜLLER's SYAKE.

$\begin{array}{llllllllll}\text { Diemenia mülleri } & \ldots & \ldots & \ldots & \ldots & \ldots & \ldots & \ldots & 411\end{array}$

Brows Srake.

$\begin{array}{llllllllll}\text { Diemenia superciliosa } & \ldots & \ldots & \ldots & \ldots & \ldots & \ldots & \ldots & \text { t1 }\end{array}$

Percy Island Sxake.

$\begin{array}{llllllllll}\text { Diemenia torquata } & \ldots & \ldots & \ldots & \ldots & \ldots & \ldots & \ldots & 43\end{array}$

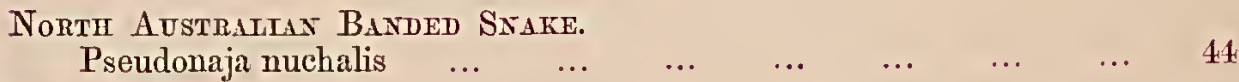

Buack Srake.

$\begin{array}{lllllllll}\text { Pseudcchis porphyriacus } & \ldots & \ldots & \ldots & \ldots & \ldots & \ldots & 46\end{array}$

Oravge-bellied Brown SNake.

New SPECIES.

$\begin{array}{llllllllll}\text { Pscudechis scutellatus } & \ldots & \ldots & \ldots & \ldots & \ldots & \ldots & \ldots & 100\end{array}$

SCARLET-SPOTTED SNAKE.

$\begin{array}{llllllllll}\text { Brachysoma diadema } & \ldots & \ldots & \ldots & \ldots & \ldots & \ldots & \ldots & 48\end{array}$

MacGillivrar's SNakf.

Brachysoma triste 
Short-TAILED SNake.

$\begin{array}{llllllllll}\text { Brachyurophis australis ... } & \ldots & \ldots & \ldots & \ldots & \ldots & \ldots & 52\end{array}$

Browr-BAKDED STAKE.

$\begin{array}{lllllllllll}\text { Hoplocephalus curtus } & \ldots & \ldots & \ldots & \ldots & \ldots & \ldots & \ldots & 53\end{array}$

Pale-headed Srake.

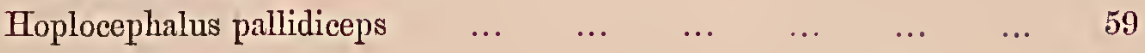

BLACK-BELLIED SYAKE.

$\begin{array}{lllllllll}\text { Hoplocephalus signatus ... } & \ldots & \ldots & \ldots & \ldots & \ldots & \ldots & 64\end{array}$

BuACK-BACKed SrAKE.

$\begin{array}{llllllllll}\text { Hoplocephalus nigrescens } & \ldots & \ldots & \ldots & \ldots & \ldots & \ldots & 68\end{array}$

Black-strIPED STake.

$\begin{array}{llllllllll}\text { Hoplocephalus nigro-striatus } & \ldots & \ldots & \ldots & \ldots & \ldots & \ldots & 70\end{array}$

NEW SPECIES.

$\begin{array}{lllllllll}\text { Hoplocephalus maculatus } & \ldots & \ldots & \ldots & \ldots & \ldots & \ldots & 100\end{array}$

RED-BELLIED SN.ike.

$\begin{array}{lllllllll}\text { Petrodymou cucullatum ... } & \ldots & \ldots & \ldots & \ldots & \ldots & \ldots & 72\end{array}$

KreFrt's Dwarf Srake.

$\begin{array}{lllllllllll}\text { Cacophis krefitii } \ldots & \ldots & \ldots & \ldots & \ldots & \ldots & \ldots & \ldots & 74\end{array}$

Fonde's Dwarf Shake.

$\begin{array}{lllllllllll}\text { Cacophis fordei } & \ldots & \ldots & \ldots & \ldots & \ldots & \ldots & \ldots & \ldots & 75\end{array}$

Harriett's Dwarf SNake.

$\begin{array}{llllllllll}\text { Cacophis harriettæ } & \ldots & \ldots & \ldots & \ldots & \ldots & \ldots & \ldots & 76\end{array}$

Buackarav's Srake.

$\begin{array}{llllllllll}\text { Cacophis blackmauii } & \ldots & \ldots & \ldots & \ldots & \ldots & \ldots & \ldots & 77\end{array}$

Buack and White Ringed Srake.

$\begin{array}{llllllllll}\text { Vermicella anuulata } & \ldots & \ldots & \ldots & \ldots & \ldots & \ldots & \ldots & 78\end{array}$

HALF-Risged SYake.

$\begin{array}{llllllllll}\text { Vermicella lumulata } & \ldots & \ldots & \ldots & \ldots & \ldots & \ldots & \ldots & 79\end{array}$

DeATH ADDER.

$\begin{array}{lllllllllll}\text { Acauthophis antarctica } & \ldots & \ldots & \ldots & \ldots & \ldots & \ldots & \ldots & 80\end{array}$

Orfarested Srake.

$\begin{array}{llllllllll}\text { Denisonia } \text { ornata... } & \ldots & \ldots & \ldots & \ldots & \ldots & \ldots & \ldots & 82\end{array}$

TASMANIA.

VFINOMOUS SNAKHS.

Brown-banded Shake.-(Black Srake and Carpet Snake of Colonists.)

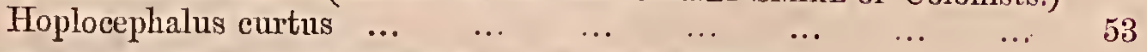

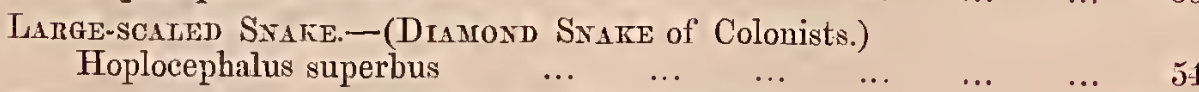

Tasmania SNake.-(Whip Srake of Colonists.)

$\begin{array}{lllllllll}\text { Hoplocephalus coronoides } & \ldots & \ldots & \ldots & \ldots & \ldots & \ldots & 62\end{array}$ 
SEA SNAKES

OBSERVED ON THE AUSTRALIAN COASTS.-ALL VENOMOUS.

Ringed Sel Srake.

Page.

$\begin{array}{llllllllll}\text { Platurus scutatus } & \ldots & \ldots & \ldots & \ldots & \ldots & \ldots & \ldots & 89\end{array}$

Fischer's Sea SNaKe.

$\begin{array}{llllllllll}\text { Platurus fischeri } \ldots & \ldots & \ldots & \ldots & \ldots & \ldots & \ldots & \ldots & 90\end{array}$

EEL-LIKE SEA Stake.

$\begin{array}{lllllllll}\text { Aipysurus anguilliformis } & \ldots & \ldots & \ldots & \ldots & \ldots & \ldots & 90\end{array}$

Browr Sea Srake.

$\begin{array}{lllllllll}\text { Aipysurus fuscus... } & \ldots & \ldots & \ldots & \ldots & \ldots & \ldots & \ldots & 91\end{array}$

Jukes'. Sea Srake.

$\begin{array}{lllllllllll}\text { Aipysurus lævis } & \ldots & \ldots & \ldots & \ldots & \ldots & \ldots & \ldots & \ldots & 91\end{array}$

Tortoise-iteaded Ringed Sea Srake.

$\begin{array}{lllllllll}\text { Emydocephalus annulatus } & \ldots & \ldots & \ldots & \ldots & \ldots & \ldots & 92\end{array}$

Tortoise-ite.doed Brown Sea Srake.

$\begin{array}{llllllllll}\text { Emydocephalus tuberculatus } & \ldots & \ldots & \ldots & \ldots & \ldots & \ldots & 93\end{array}$

Dumeril's Sea Strake.

$\begin{array}{lllllllllll}\text { Disteira doliata } & \ldots & \ldots & \ldots & \ldots & \ldots & \ldots & \ldots & \ldots & 94\end{array}$

Bibrox's SEA Srake.

$\begin{array}{lllllllll}\text { dealyptus superciliosus ... } & \ldots & \ldots & \ldots & \ldots & \ldots & \ldots & 94\end{array}$

STOKES' SEA STAKE.

$\begin{array}{llllllllll}\text { Hydrophis stokesii } & \ldots & \ldots & \ldots & \ldots & \ldots & \ldots & \ldots & 95\end{array}$

Belcher's SeA Srake.

$\begin{array}{llllllllll}\text { Hydrophis belcheri } & \ldots & \ldots & \ldots & \ldots & \ldots & \ldots & \ldots & 95\end{array}$

Elegart Sea Srake.

$\begin{array}{lllllllll}\text { Hydrophis elegans } & \ldots & \ldots & \ldots & \ldots & \ldots & \ldots & \ldots & 96\end{array}$

Ered Sea Sxake.

$\begin{array}{llllllllll}\text { Hydrophis ocellata } & \ldots & \ldots & \ldots & \ldots & \ldots & \ldots & \ldots & 97\end{array}$

Bengat Sea Srake.

$\begin{array}{lllllllllll}\text { Enhydrina bengalensis } & \ldots & \ldots & \ldots & \ldots & \ldots & \ldots & \ldots & 98\end{array}$ Yellow-BeLLied Sea SNake.

$\begin{array}{lllllllllll}\text { Pelamis bicolor } & \ldots & \ldots & \ldots & \ldots & \ldots & \ldots & \ldots & \ldots & 98\end{array}$ 


\section{ALPHABETICAL INDEX. .}

Acalyptus, 88, 94.

A.canthophis, 79.

Aipysurus, 88, 90.

amethystiuus, Liasis, 35.

anguilliformis (Aipysurus), 90.

auguilliformis (Thalassopis), 90.

annulata, Diemenia, 41.

annulata, Vermicella, $7 \mathrm{~s}$.

anuulatus, Emydocephalus, 92.

antaretica, Acanthophis, 80 .

Aspidiotes, 33.

ater, Hoplocephahıs, 55.

Australian Bockadam, 22.

Australian Ground Snake, 20.

Australiau Fresh-water Snake, 20.

Australian Short-tailed Suakc, 52.

Australiau Tropidonotus, 20.

anstralis, Bracliyurophis, 52.

anstralis, Ccrbcrus, 22.

australis, Coronella, 20 .

australis, Naja, 46, 47.

australis, Pseudechis, 47 .

australis, Simotes, 52.

australis, Typhlops, 18.

belcheri, Aturia, 95.

belcheri, Hydrophis, 95.

Belcher's Sea Suake, 95.

beugalensis, Enhydrina, 98.

Bengal Sea Snakc, 9S.

Bibion's Sea Suake, 94 .

bicolor, Hydrus, $9 \mathrm{~s}$.

bicolor, Pelamis, 98.

bicolor, Typhlops, 19.

binaculata, Furina, 51.

bimaculatum, Brachysoma, 51.

bituberculatus, Typh̆lops, 17 .

Black and White Ringed Snake, 78.

Black-backed Snake, 68 .

Black-bellied Suake, 64 .

Black-headed Snake, 33.

blackmanii, Cacophis, 77 .

Blackman's Snake, 77.

Black-naped Snake, 65.

Black Snake, 46.

Black-striped Snake, 70.

Bliud Snakes, 10.

Braclyssoma, 48.

Brachyurophis, 51.

Broad-headed Snake, 56.
Brown-banded Snake, 53 .

Brown Sea Snake, 91.

Brown Snake, 41.

Browu Tree Silake, 26.

bungaroides, Alecto, 56 .

bungaroides, Hoplocephalus, 56.

bungaroides, Naja, 56.

Cacophis, 73.

calligastra, Deudrophis, 25.

calowotos, Brachysoma, 50.

calouotos, Furina, 50.

cariuata, Tropidechis, 71.

carinatus, Hoplocephalus, 71 .

Carpet Snake, 31.

childrenii, Liasis, 34 .

Children's Rock Snake, 3 t.

Cerberus, 22.

Clarence Rirer Suake, 71.

Colnbridæe, 19.

Colubrides, 10, 19.

Coronata, Alecto, 62.

coronatus, Elaps, 62.

coronatus, Hoplocephalus, 62.

Coronella, 19.

corouoides, Hoplocephalus, 62.

Crowned Snake, 62.

cucullata, Diemausia, 72 .

curta, Naja, 53.

curtus, Hoploceplialus, 53.

Death Adder, 80.

Demansia, 3S.

Dendrophidx, 23.

Dendrophis, 23.

Denisonia, $\$ 2$.

Descrt Suake, 67 .

Diemansin, 38.

Diemenia, 38.

Dicmennia, 38.

diadema, Brachysona, 48.

diadema, Calamaria, 48.

diadcma, Furina, $4 \mathrm{~S}$.

Diamond Snake, 29.

Dipsadidæ, 25.

Dipsas, 25.

Disteira, 88, 93 .

doliata, Disteira, 91.

doliata, Hydrophis, 96 .

dumerillii, Disteira, 94.

Dumeril's Sea Sinake, 91. 
Eel-like Sea Snake, 90.

Elapidx, 37.

elegans, Aturia, 96.

elegans, Hydrophis, 96.

Elegant Sea Suake, 96.

Emydocephalus, 88, 92.

Enhydrina, 88, 98.

Eyed Sea Snake, 97

Family of Blind Snakes, 17.

Family of Colubrides, 19.

Family of Day Tree Snakes, 23.

Family of Elapides, 37.

Family of Night Tree Snakes, 25.

Family of Roek Snakes, 27.

Family of Sea Snakes, 83.

Family of T'me Fresh-water Snakes, 21.

fischeri, Platurus, 90.

Fischer's Sea Snake, 90.

flavescens, Triglyphodon, 26.

Fliuders' Snakc, 55.

fordei, Cacophis, 75.

Forde's Dwarf Snake, 75 .

Furina, 50.

fusca, Dipsas, 26.

fuseus, Aipysurus, 91.

gilbertii, Nardoa, 35.

Gilbert's Rock Snake, 35.

gouldii, Elaps, 60.

gouldii, Hoplocephalus, 60 .

Gould's Snake, 60.

Gray's Blind Snake, 18.

Green Tree Snake, 23.

Grey Snake, 40.

gintheri, Typhlops, 17.

Giintber's Blind Snake, 17.

Half-ringed Snake, 79.

harrietta, Cacophis, 76.

Harriett's Snake, 76.

Homalopsida, 21.

Hoplocephahus, 53.

Hydrophide, 37, 83.

Hydrophis, 88, 95.

Innocuous Snakes, 16.

Jukes' Sen Snake, 91.

krefftii, Cacophis, 74.

Kreff't's Dwarf Snake, 74.

kubynii, Pseudoelaps, 41.

Large-sealed Snake, 54.

Liasis, 34.

lnnulata, Vermicella, 79.

Maegillivray's Snake, 50.

mastersii, Hoplocephalus, 63.

Masters' Snake, 63.

- melanocephalns, Aspidiotes, 33.

minor, Hoplocephalus, 67.

Morelia, 29.

mïlleri, Diemenia, 41.

müllcri, Elaps, 41.

mülleri Pseudoëlaps, 41.
Müller's Snake, 41.

Myron, 22.

Nardoa, 35.

nigrescens, Hoplocephalus, 68 .

nigrescens, Typhlops, 18.

nigriceps, Hoplocephalus, 68.

nigrostriatus, Hoplocephalus, 70.

Non-venomous Snakes, 10.

North Australian Banded Snake, 44.

Northern Tree Snako, 25.

nuchalis, Pseudonaja, 44.

occipitale, Rabdion, 48.

ocellata, Hydrophis, 97.

olivacea, Diemcnia, 39.

olivacea, Liasis, 35.

Olive-green Rock Snake, 35.

Orange-bellied Brown Snake, 47.

Ornamented Snake, 82.

ornata, Denisonia, 82.

ornata, Elaps, 48.

ornatus, Glyphodon, 48 .

ornata, Pelamis, 98.

Palc-headed Snake, 59.

pallidiceps, Hoplocephalus, 59.

Pelamis, 88, 98.

Perey Island Snake, 43.

Peters' Blind Snake, 17.

Petrodymon, 72.

picturatus, Tropidonotus, 20.

Platurus, S8.

polygrammicus, Typhlops, 17.

porphyriaca, Naja, 46 .

porphyriacus, Coluber, 46 .

porphyriacus, Pseudechis, 46.

Port Lincoln Snake, 61.

preissi, Typhlops, 19.

Preiss' Blind Snake, 19.

psannnophidius, Pscudoëlaps, 38.

psammophis, Diemenia, 38.

psammophis, Elaps, 40.

Pseudechis, 45.

Pseudoëlaps, 38.

Psendonaja, 44.

punctulata, Dendrophis, 23.

Pythonidx, 27.

Pythons, 10.

ramsayi, Hoplocephalus, 66.

Ramsay's Snake, 66.

Red-bellied Snake, 72.

Rock Snakes, 10.

reticulata, Diemenia, 39, 40.

Schmidt's Blind Snake, 19.

Short-tailed Snake, 52.

richardsonii, MIyron, 22.

Richardson's Fresh-water Snake, 23.

Ringed Sea Suakc, 89.

rïppelli, Typllops, 18.

Rüppell's Blind Snake, 18.

Scarlet-spotted Snake, 48. 
Schlegel's Blind Snake, 17. Schlegel's Snake, 38. scutatus, Platurus, $\$ 9$. scutellatus, Pseudechis, 100. signatus, Hoplocephalus, 61. sordellii, Pseudoëlaps, 41 . spectabilis, Hoploceplialus, 61 . spilotes, MIorelia, 29.

Spotted Snake, 50. stephensii, Hoplocephalus, 58. Stephens' Banded Snake, 58. stokesï, Hydrophis, 95, 100. stokesii, Hydrus, 95. Stokes' Sea Suake: 95. superbus, Hoplocephalus, 54 . supereiliosa, Diemenia, 41. superciliosus, Acalyptus, 94. superciliosus, Psendoëlaps, 41. Tasmauian Snake, 62.

temmiuckii, Typhlops, 100.

Temporal Desert-Snake, 65 . temporalis, Hoplocephalus, 65. textilis, Furina, 41 .

torquata, Diemenua, 43.

Tortoise-headed Ringed Sea Snake, 92.

Tortoise-headed Brown Sea Snake, 93.

Tree Snakes, 10.

Triglyphodon, 26.

triste, Brachysoma, 50.

tristis, Glyphodon, 50.

Tropidechis, 71.

Tropidouotus, 20 .

tuberculatus, Enydocephalus, 93.

unguirostris, Typhlops, 100.

variegata, Alecto, 56 .

variegata, Hydrophis, 98 .

variegata, Morelia, 31.

variegatus, Hoplocephalus, 56.

Tenomous Colubrime Snakes, 10, 37.

Termicella, 78.

Verreaux's Suake, 51.

West Australian Blind Surke, 18. wiedii, Typhlops, 100.

Tellow-bellied Sea Snake, 98 .

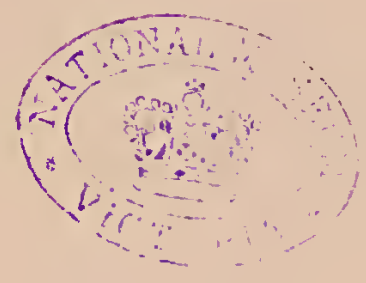




\title{
P工ATHS.
}

\author{
PLATE I. \\ NON-VEINOIMOUS. \\ Diamoso Srake-Morelia spilotes.
}

\section{PLATE II.}

NON-VENOMOUS.

Carpet Sfake-Moretia variegata.

\section{PLA'TE III.}

INON-VFNOMOUS.

Black-Headed Sxafe-Aspidioles melanocephalus.

\section{PLATE IV.}

\section{NON-VENOMOUS.}

Green Tree Srake-Dendrophis punctulata.

\section{PLATE V.}

\section{NON-VENOIMOUS.}

$\left.\begin{array}{l}\text { 1. Skull (side view) } \\ \text { 2. Head (side view) }\end{array}\right\}$ of the

Diamond Srake-Morelia spilotes.

3. Head (upper view) $\}$ of

3a. Head (side view) $\}$ of

Gizbert's Rock Srake-Nardoa gilbertii.

4. Head (side riew) of the

Buack-HEaded Rock SNate-Aspidiotes melanoeephalus.

5. Head (upper view) $\}$ of the

5a. Head (side view) $\}$ of the

New Ireuand Rock Srake-Liasis ametlystimus. 
6. Head (upper view)

6a. Head (side view) $\}$ of the

Green Tree Srake-Dendrophis punctulata.

$\left.\begin{array}{l}\text { 7. Head (upper riew) } \\ 7 a \text {. Head (side view) }\end{array}\right\}$ of the

Brows Tree Srake-Dipsas fusca.

8. Head (upper view) ?

8 . Head (side view) $\}$ of the

Fresh-water Srake-Tropidonotus picturatus.

$\left.\begin{array}{l}\text { 9. Head (upper view) } \\ 9 a \text {. Head and portion of body }\end{array}\right\}$ of

Preiss' Bund SNake-Typhlops preissi.

10. Head (side riew)

13. Head (upper view) $\}$ of

13a. Tail

Schurdt's Burnd SNake-Typhlops bicolor.

11. Head (side view) of

RÜPPELL's Butrn SraKe-Typhlops rüppclli.

12. Head (upper view)

12a. Head (side view)
12b. Tail of

Gray's Burnd Sxake-Typhlops nigrescens.

\section{PLATE VI.}

1. Skull of

\section{VFINOMOUS.}

Americay Rattlessake-Crotalus durissus.

2. Skull of

Australdar Black Srake-Pseudechis porphyriacus.

3. Head of

West Austratiat Crowned Srake-Hoplocephalus coronatus.

$\left.\begin{array}{l}\text { 4. Head (upper view) } \\ \text { 4a. Head (side view) }\end{array}\right\}$ of the

BLACK-BACKED SNAKE-Hoplocephalus nigrescens.

$\left.\begin{array}{l}\text { 5. Head (upper view) } \\ \text { 5a. Head (side view) }\end{array}\right\}$ of the

Temporat Desent Sxake-Hoplocephalus temporalis.

6. Head (upper view)

6a. Head (lower view) $\}$ of the

6b. Head (side view)

BROAD-HEADED SNAKE-Hoplocephalus variegatus. 
PLATES.

хxiii

7. Head (upper riew) of

Stephens' Barded Srake-Hoplocephalus stephensii.

8. Head (upper view) of the

Desert STake-Hoplocephalus minor.

$\left.\begin{array}{l}\text { 9. Head (upper riew) } \\ 9 a \text {. Head (side view) }\end{array}\right\}$ of the

SPotTed-IIEAded SNaKe-Diemcnia olivacea.

$\left.\begin{array}{l}\text { 10. Head (upper riew) } \\ \text { 10a. Head (side view) }\end{array}\right\}$ of the

RED-BELdiEd SNake-Petrodymon cueullutum.

$\left.\begin{array}{l}\text { 11. Head (upper view) } \\ \text { 11a. Head (side view) }\end{array}\right\}$ of the

Oratge-Beluted Brown Srake-Pseudechis australis.

PLATE VII.

VENOMOUS.

Browy Sxake-Diemenia superciliosa.

\section{PLATE VIII.}

VENOMOUS.

Buack Srake-Pseudechis porphyriacus.

\section{PLATE IX.}

VENOMIOUS.

Brown-BAXded SNAKE-Hoplocephalus curtus.

\section{PLATE X.}

VENOMOUS.

DEATH ADDER-Acanthophis antarctica.

\section{PLATE XI.}

1. Head (upper view) of the

PALE-HEADED SXAKE-Hoplocephalus pallidiceps.

2. Head (upper view) of

RAנrSAY's SxAKE-Hoplocephalus ramsayi. 
3. Head (upper view, enlarged)

3a. Head (side view)

32. Head (lower view)

3c. Portion of body

3d. Tail

Short-TAtLed SraKe-Brachyurophis australis.

4. Head (upper view, enlarged to twice its natural size) of the Ordameteded Srake-Denisonia ornata.

5. Head (upper riew)
$5 a$. Portion of body enlarged to twice the natural size, of KrefFt's DwarF Srake-Cacophis kreffiii.

6. Head (upper riew) of the BRown-Bayded SNAKE-Hoplocephalus curtus.

7. Head (upper view) of the DEATI ADDER-Aeanthophis antarelica.

8. Head (upper view)' of the BLACK SYAKE-Pseudechis porphyriacus.

9. Head (upper view) of the LARGE-SCALEU SraKE-Hoplocephalus superbus.

$\left.\begin{array}{l}\text { 10. Head (upper riew) } \\ 10 a \text {. Portion of body }\end{array}\right\}$ of a young

Browr Srake-Dienenia supercitiosa.

11. Head (upper view) of

FLINDERs' STaKE-Hoplocephalus ater.

12. Head (upper view) and ?

12a. Portion of the body $\}$ of the

BLack axd Wmite Ruxged Sx̃ake-Termicella asnulata.

13. Head (upper riew) of

Harmeter's Dwarf Srake-Cacophis harrietta.

\section{PLA'IE XII.} VENOMTOUS.

$\left.\begin{array}{l}\text { 1. Head (npper riew) } \\ \text { 1a. Head (side view) }\end{array}\right\}$ of the

Tasmaniar Sra KE-Hoplocephalus coronoides.

2. Head (upper view) of

GouLds's Sratre-Hoplocephalus gouldii.

3. Head (upper view) of the

Bulck-STRIPED SrakE-Hoplocephalus nigrostriatus. 
4. Head (upper view) of the

Pont Lincoun Sxake-Hoplocephalus spectabilis.

5. Head (upper view) of the

BLACK-BELLIED SNAKE-Hoplocephalus signatus.

6. Head (upper view) of

Masters' Srake-Hoplocephalus mastersii.

7. Head (upper view) of the

BLACK-NAPED SraKe-Hoplocephalus nigriceps.

8. Head (upper view) $\}$ of

Sa. Portion of body $\}$ of

FordE's DWARF SraKE-Cacophis fordei.

9. Head (upper view) of

Buachands Srafe-Caeoplis blackmanii.

10. Head (side riew) of the

Grer Srake-Diemenia reticulata.

$\left.\begin{array}{l}\text { 11. Head (side view) } \\ 11 a \text {. Head (upper view) }\end{array}\right\}$ of the

Perct Istaxd Srate-Dicmenia torquata.

12. Head (upper view) of the

Scarlet-Spotted SNake-Brachysoma diadema.

13. Head (upper view) of the

North Austratisx Baxded SNake-Pseudonaja muchatis.

14. Head (upper view)

14a. Portion of body $\}$ of the

Hatf-Rniged Srake-Termicella Tunulata.

$\left.\begin{array}{l}\text { 15. Head (upper view) } \\ \text { 15a. Portion of body }\end{array}\right\}$ of the

Ered SEA SNAKE-Hydrophis ocellata.

16. Head (upper riew)

16a. Head (side riew) $\}$ of the

16z. Portion of body $\}$

Elegatt Sei Stake-Hydroplis elegans.

17. Head (side view) of

Stokes' SeA Sxake-Hydrophis stokcsii.

18. Head (upper view) of the

Rivaed SEA SNake-Platurus scutatus.

19. Head (side riew) of the

Yelrow-belited Sea SNaKe-Pelamis bicolor. 



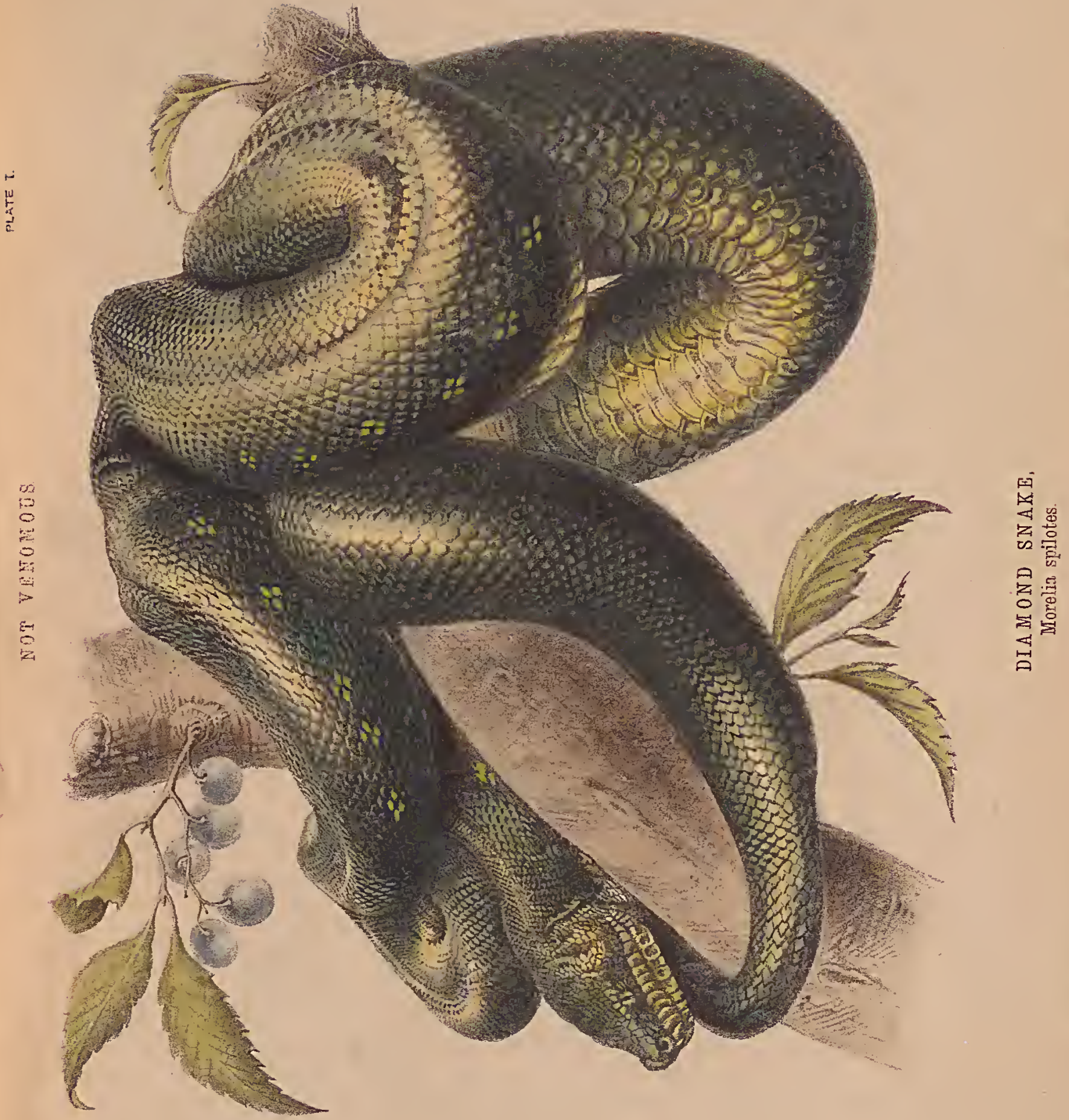





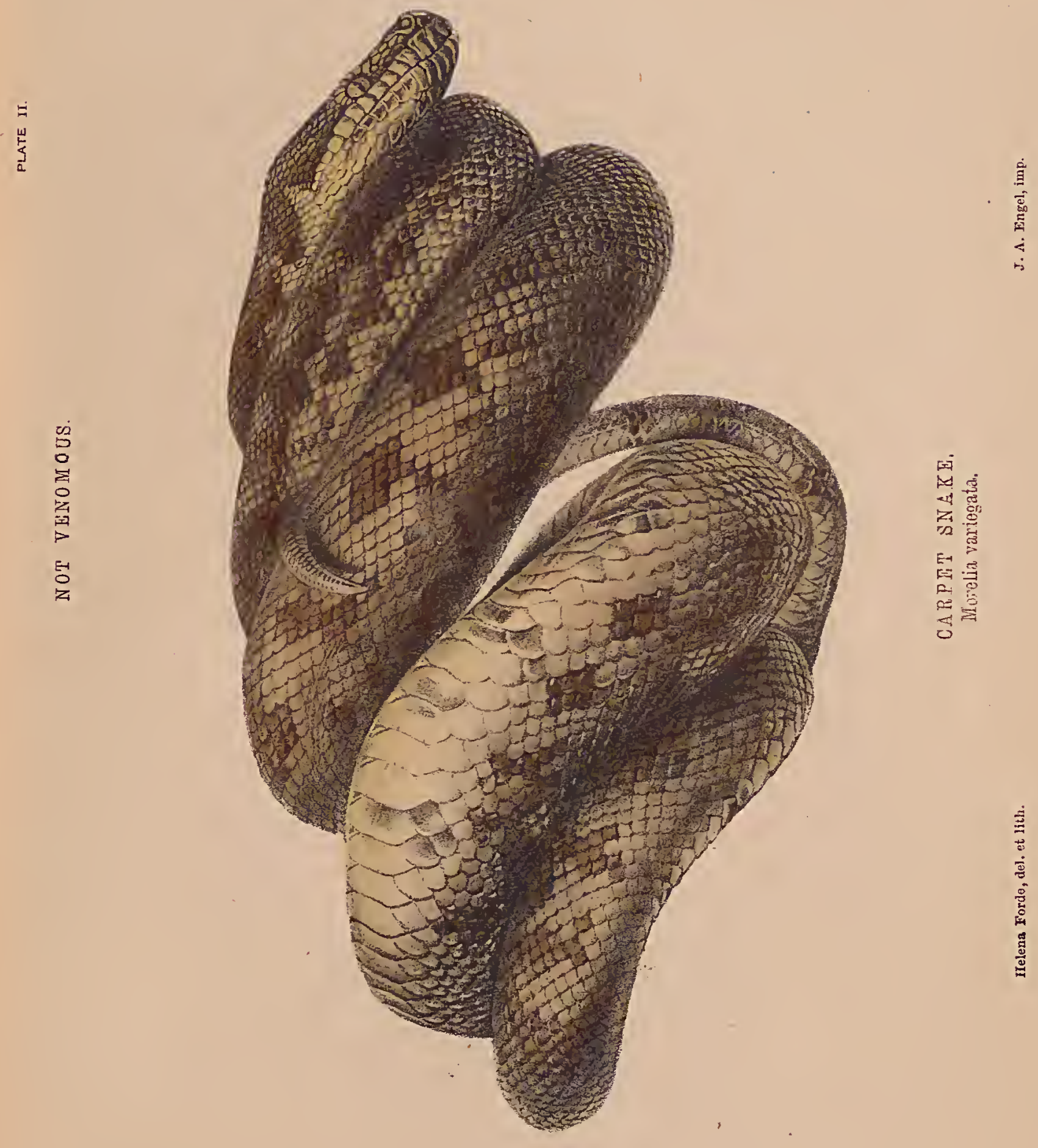





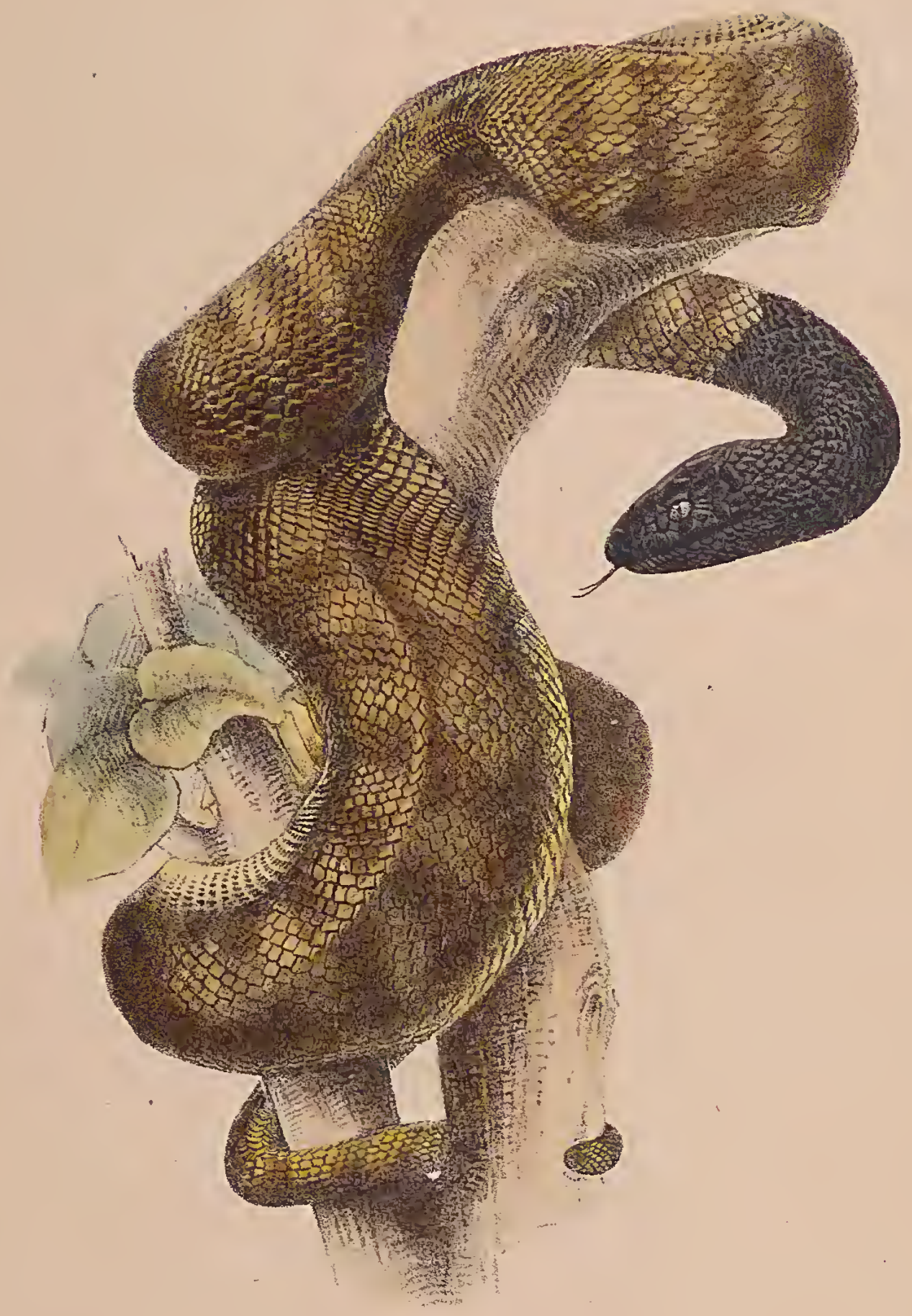

BLACK-HEADED SNAKE, Aspidiotes melanocephalus. 


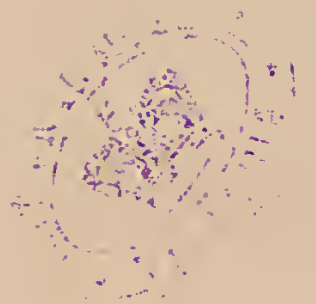

, 


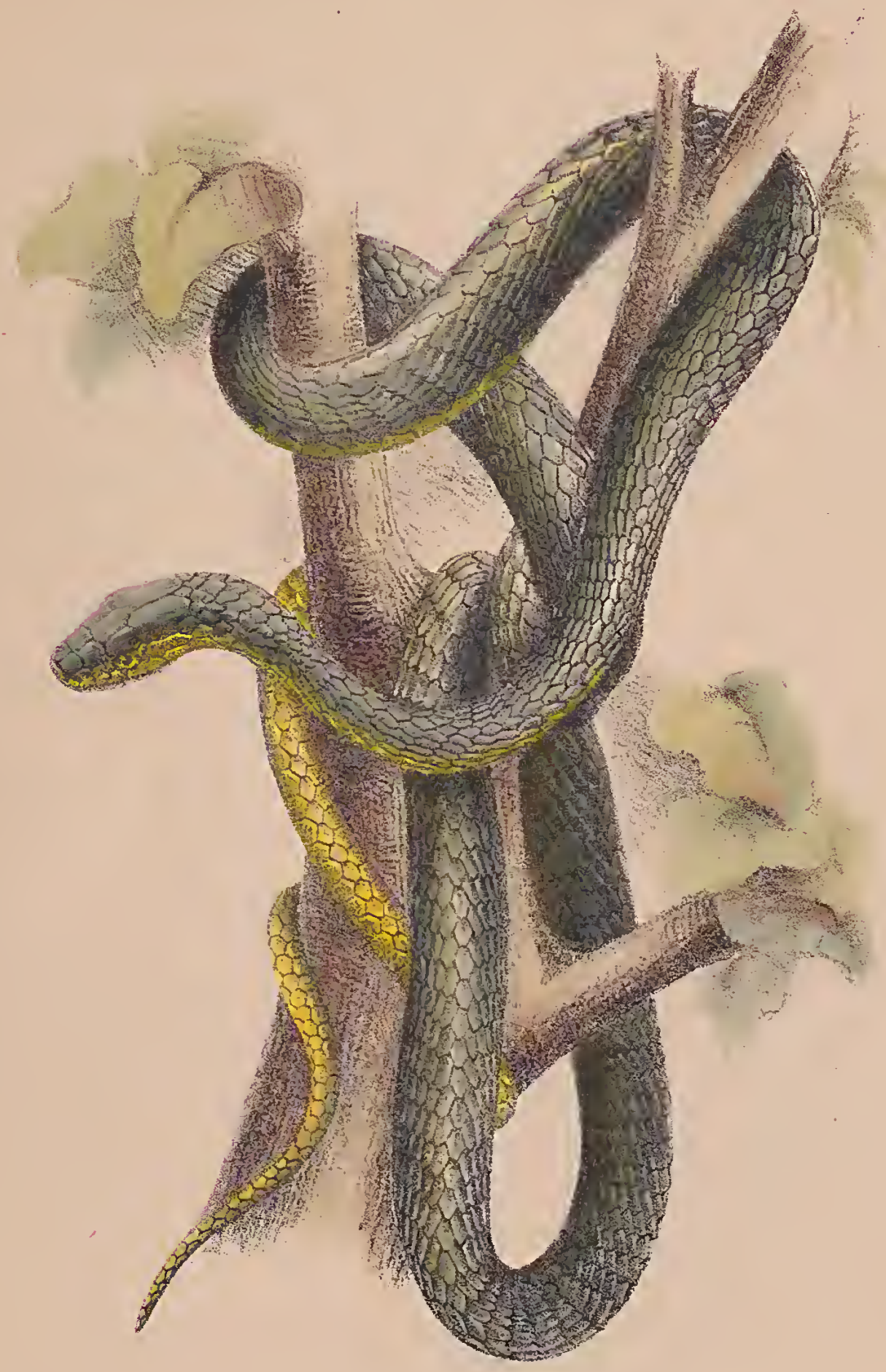

GREEN TREE SNAKE,

Dendrophis punctulata. 

NOT $\nabla E N O M O U S$.
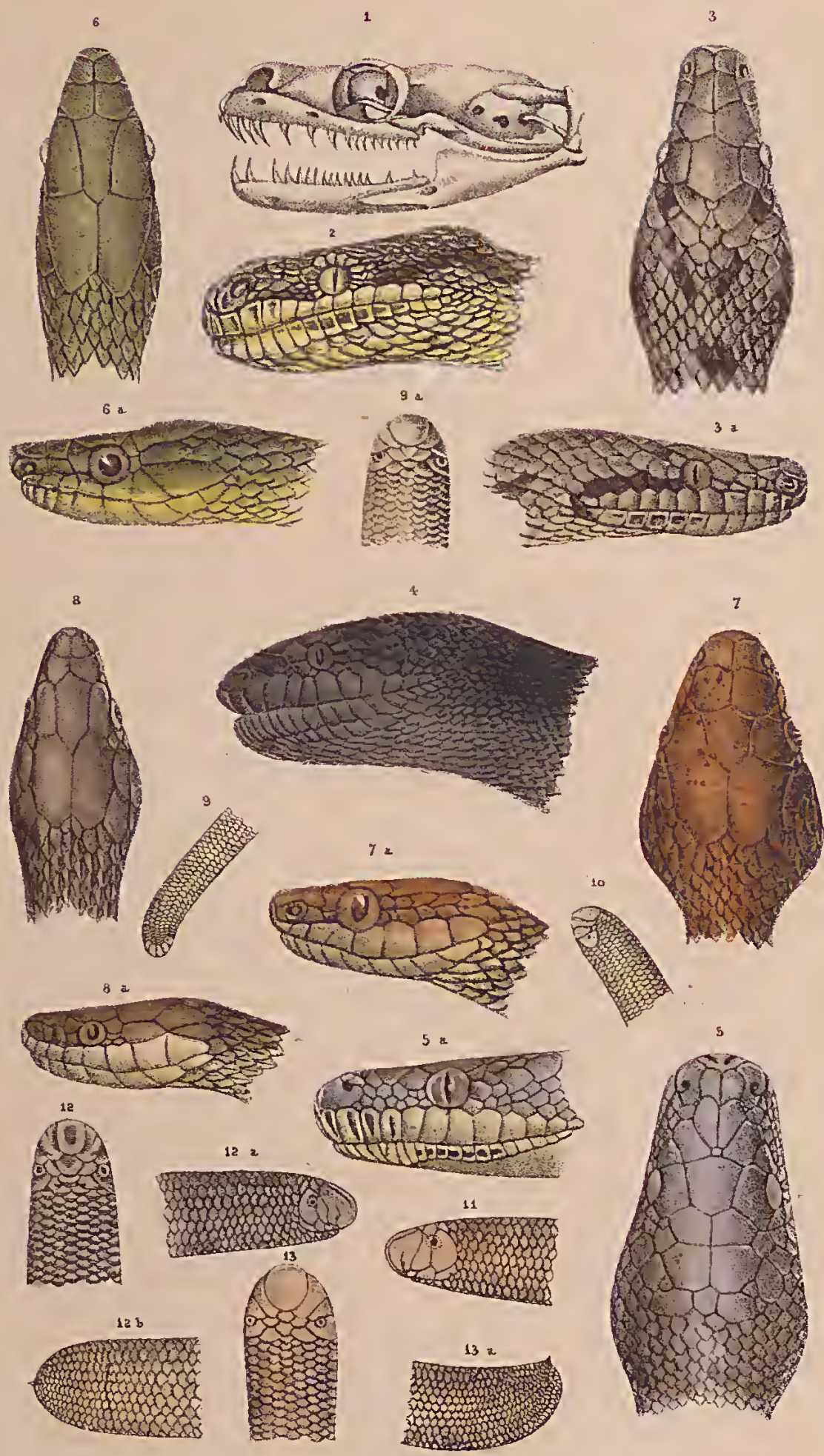


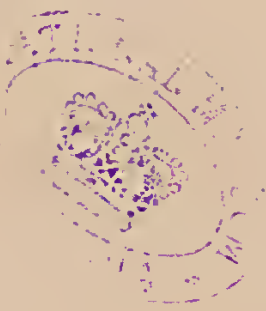


VENOMOUS.

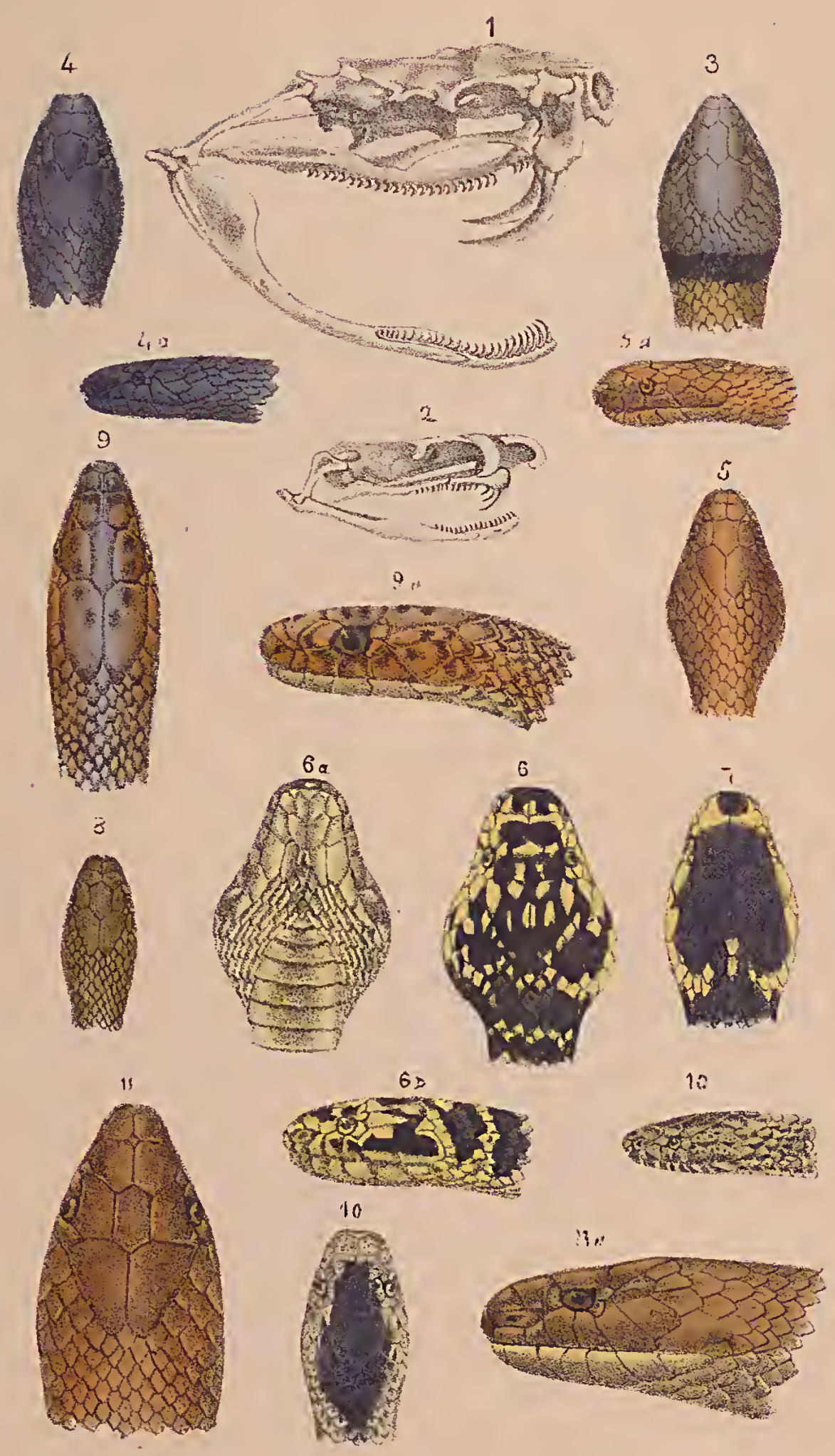

HEADS OF AUSTRALIAN SNAKES,

No. 1. Skull of American Rattle Snake, (Crotalus durissus.)

No. 2. Skull of Australian Black Snake. (Pseudechis porphyriacus.) 



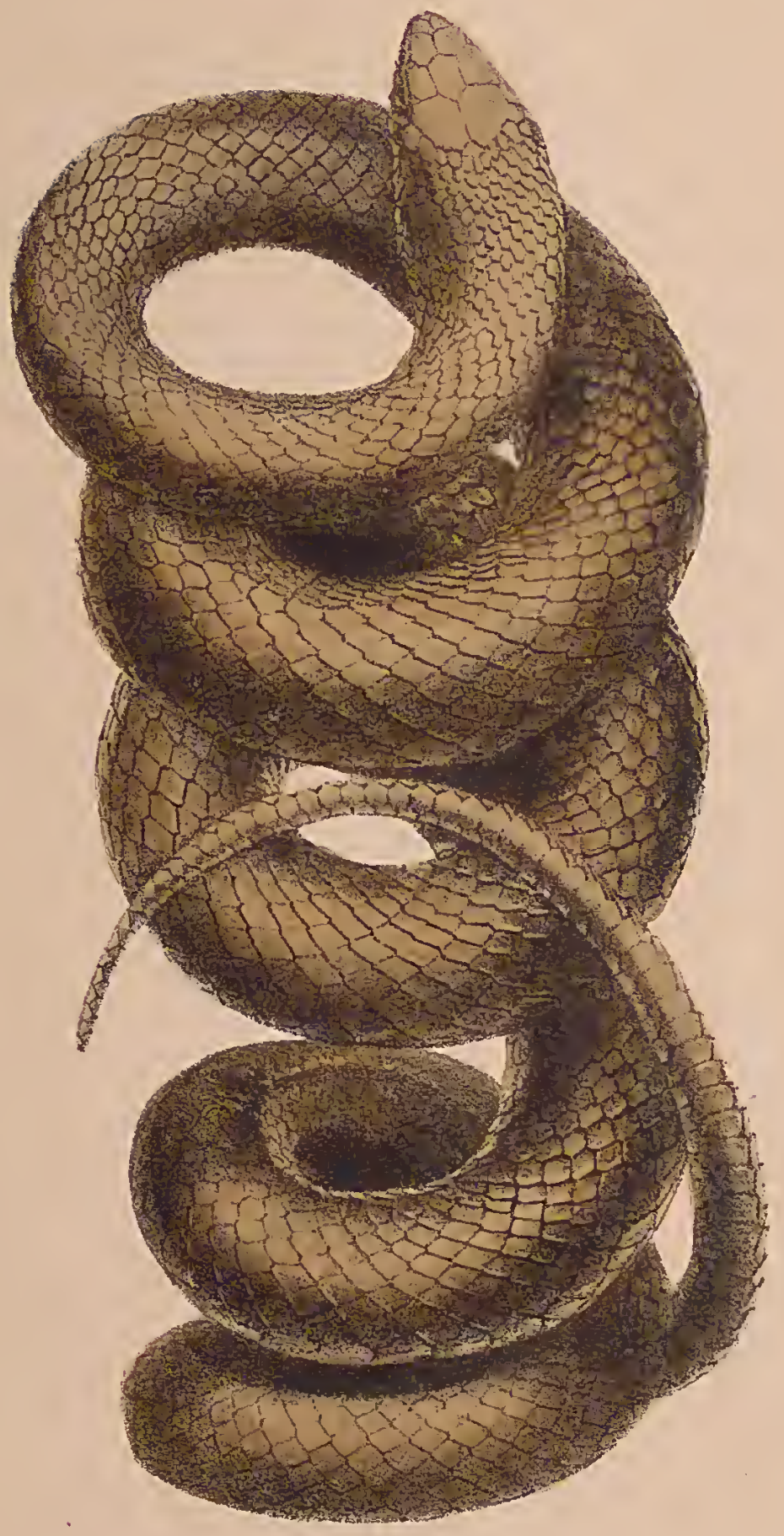

BROWN SNAKE,

Diemenia superciliosa. 



$$
\xi
$$



VENOMOUS.

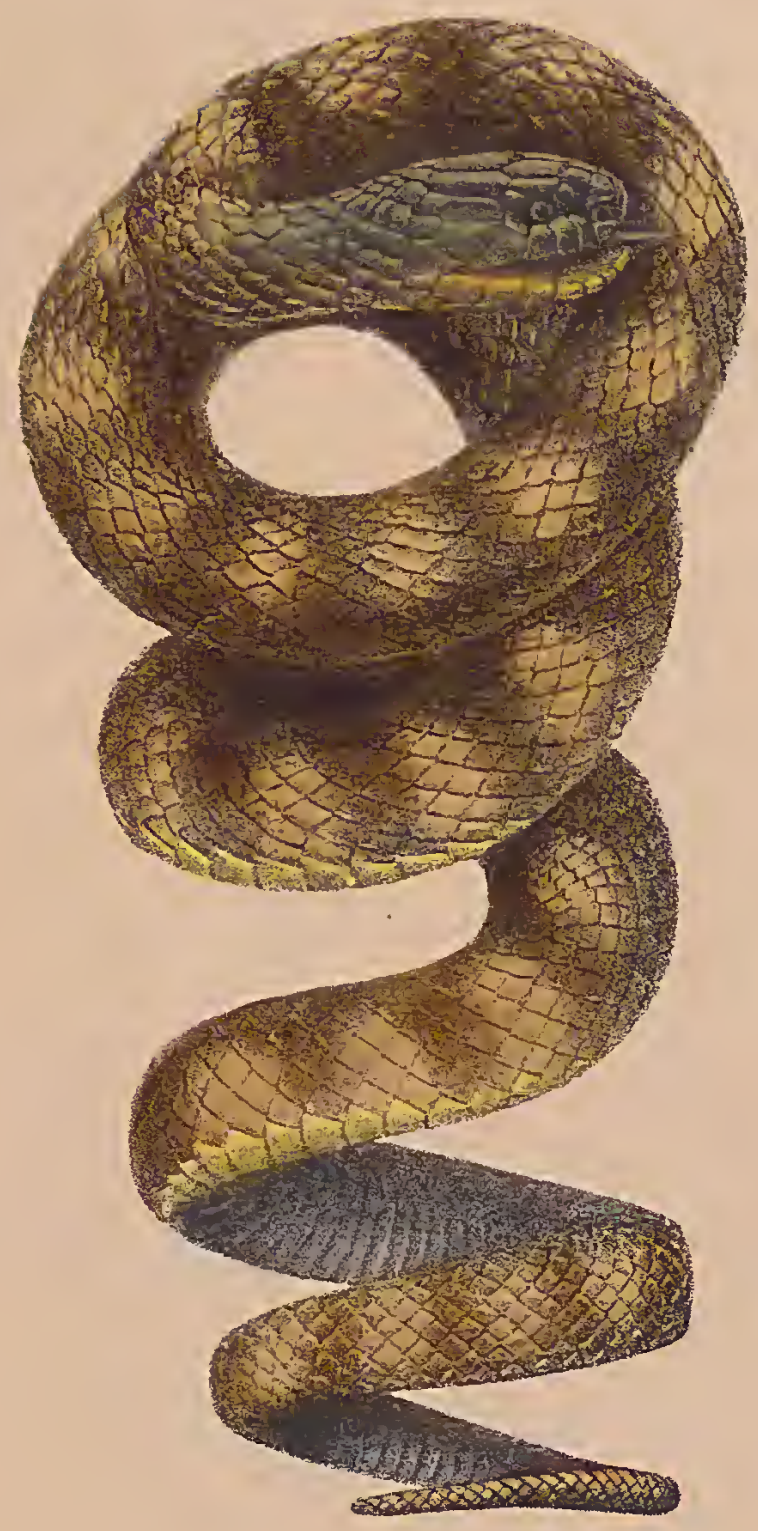

BROWN-BANDED SNAKE,

Hoplocephalus curtus. 



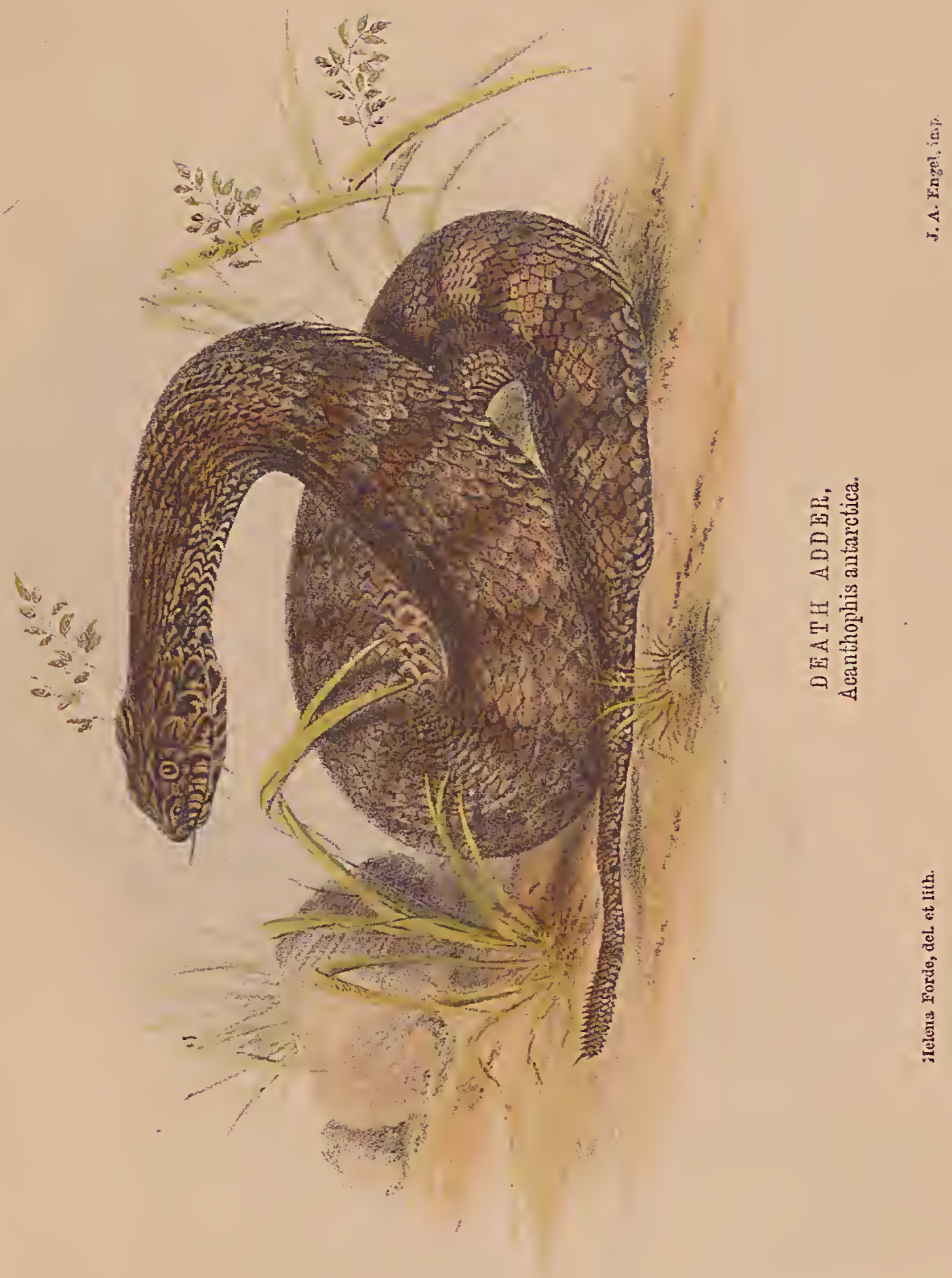



VINOMOUS.

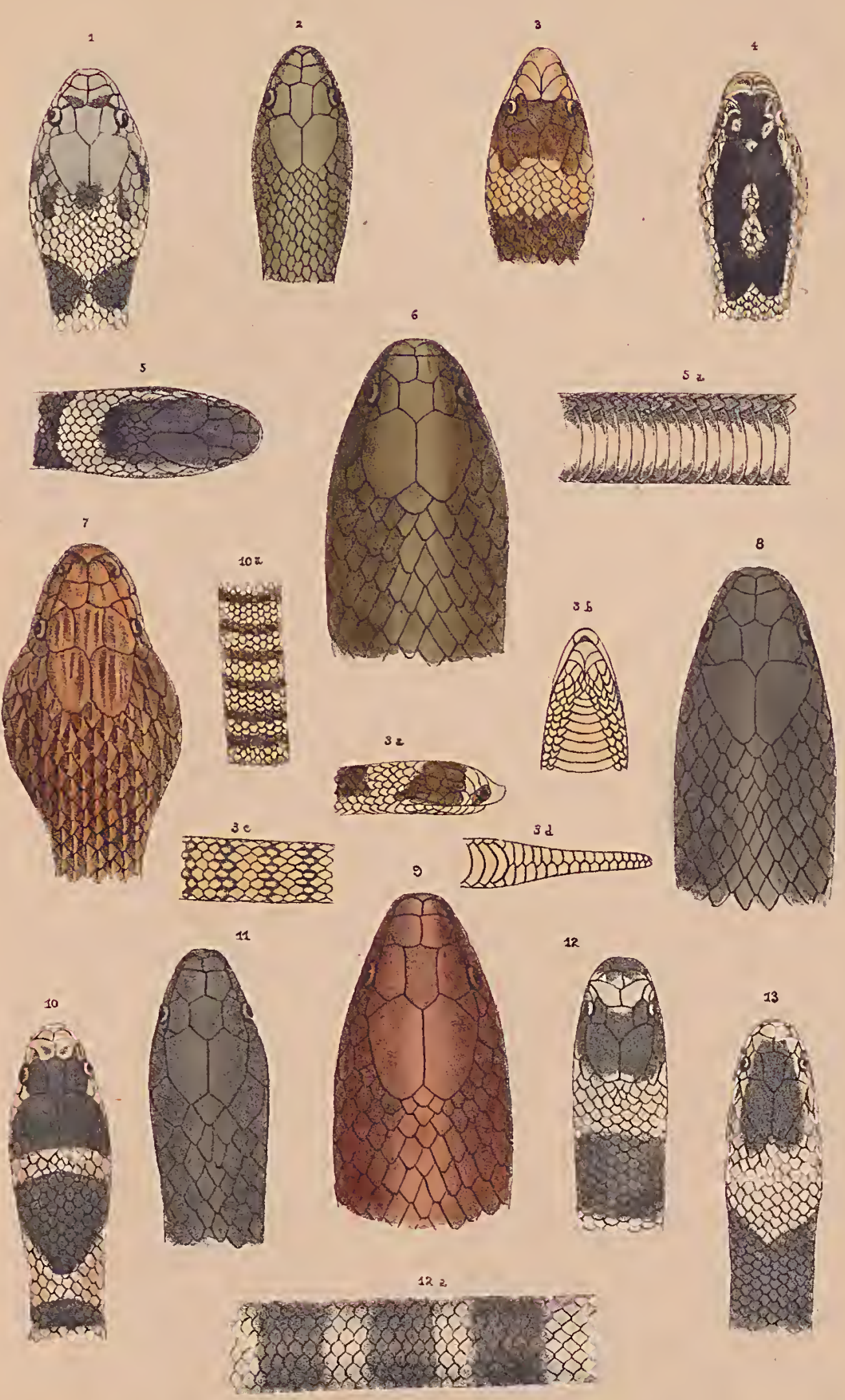

AUSTRALIAN SNAKES 


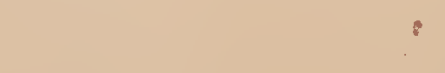


VENOMOUS.
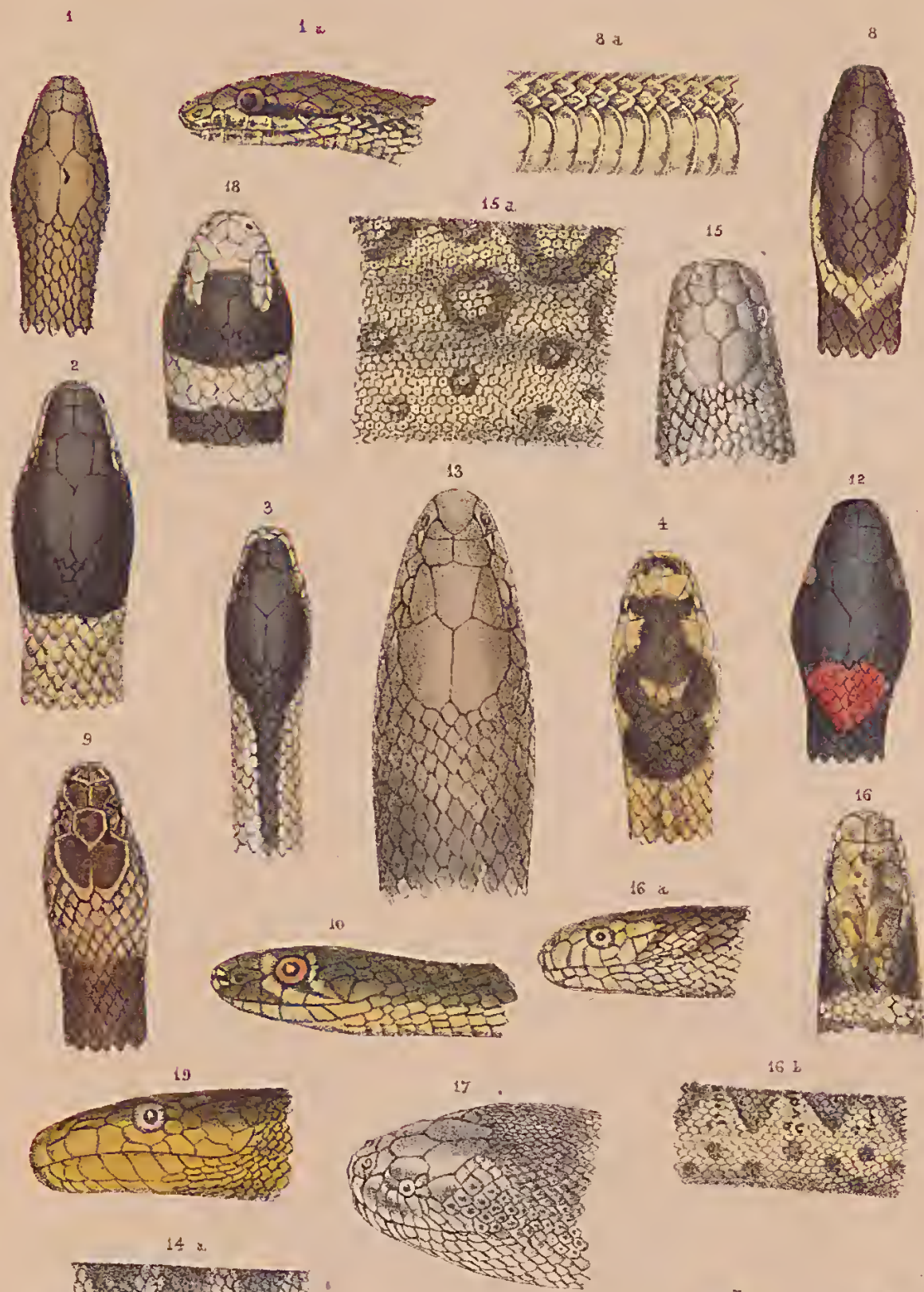

161

$14:$
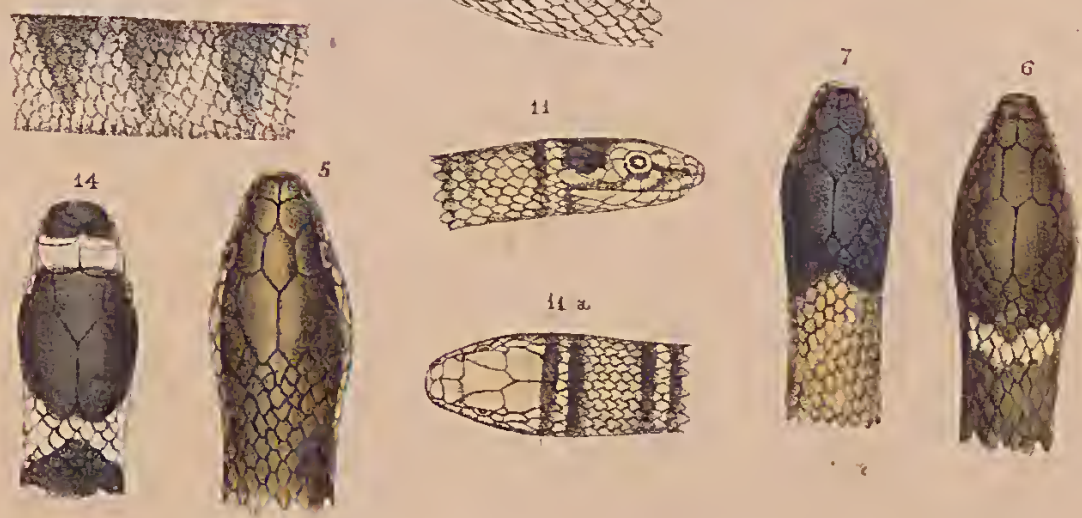

A USTRALIAN SNAKES. 




t.

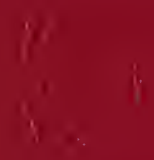

